\title{
A taxonomic revision of the genus Cycas (Cycadaceae) in Australia
}

\author{
K.D. Hill
}

\begin{abstract}
Hill, K.D. (National Herbarium of New South Wales, Royal Botanic Gardens, Mrs Macquaries Road, Sydney, NSW 2000, Australia) 1996. A taxonomic revision of the genus Cycas (Cycadacene) in Australia. Telopea 7(1): 1-64. A taxonomic revision of the genus Cycas in Australia is presented, with a key to all species and maps of distribution. Sixteen species not treated in earlier papers are described and illustrated. Twenty-seven species are recognised, six of them described here as new (C. badensis, C. maconochiei, C. semota, C. tuckeri, C. xipholepis and C. yorkiana). Six new subspecies are recognised (C. amhemica subspp. natja and muninga, C. maconochiei subspp. lanata and viridis, and C. media subspp. ensata and banksii), and C. lane-poolei is reinstated from synonymy. All Australian species are placed in section Cycas subsection Endemicae, with seven series recognised and described, five of them new.
\end{abstract}

\section{Introduction}

This paper concludes a review of the genus Cycas in Australia (earlier papers are Hill 1992, 1993, 1994a). The study was initiated during preparation of an account of the Australian 'gymnosperms' for Volume 48 of the Flora of Australia, during which the taxonomic 'status quo' was found to be inadequate. Infrageneric relationships, evolution and biogeography are discussed elsewhere (Hill 1996). Morphological terminology follows earlier papers in this series, and a full generic description can also be found in Hill (1992).

\section{Materials and methods}

All taxa have been studied in the field except $C$. arenicola and $C$. desolata. Herbarium collections held by BM, BRI, CANB, CBG, DNA, K and $\mathrm{L}$ have been examined (herbarium abbreviations follow Holmgren et al. 1990).

\section{Taxonomic history}

The genus Cycas was described by Linnaeus $(1753,1754)$ with a single species C. circinalis, although much of the material he cited has since been separated as different taxa. C. circinalis as now circumscribed (see Hill 1995) is based on Todda Panna of Rheede (1682), from the Malabar coast of south-western India, as lectotypified by Stevenson (in Jarvis et al. 1993).

Robert Brown (1810) described the first Australian species, C. media and C. angulata. The next significant study of Cycas was that of Miquel, who published a series of works on the cycads (e.g. 1840, 1842, 1847, 1868, 1869). He named C. gracilis and C. armstrongii from Australia, among many non-Australian species. Bentham (1873) reduced all Australian species to $C$. media, with the qualification that the group was 
complex and required further critical study, particularly in the field. Some subsequent Australian treatments have followed Bentham (e.g. Ewart \& Davies 1917).

Mueller $(1874,1876,1882)$ subsequently described C. kennedyana, C. normanbyana and C. cairnsiana. Bailey $(1883,1902,1913)$ uncritically accepted the species as described by Mueller.

Gardner (1922, 1923) recognised two additional species, C. basaltica and C. lane-poolei, both from the Kimberley region of Western Australia. At about the same time, Fitzgerald (1918) described C. furfuracea from the same region. Pilger (1926) ignored all described taxa from this region and from the Northern Territory, recognising only C. media, C. caimsiana and C. normanbyana in Australia.

Schuster (1932) included C. armstrongii and C. angulata in the type variety of C. media, and recognised C. furfuracea, C. basaltica and C. lane-poolei as three distinct varieties of C. media. Schusterís elaborate infraspecific hierarchies were often nonsensical (see Johnson 1959), and little significance can be attached to this treatment. Schuster did, however, propose an infrageneric breakdown that is more defensible, and, with modification, will be followed here (see Hill 1993b).

Johnson (1959) revised the Australian cycads other than Cycas, and established the currently accepted family classification. He recognised some of the problems in Cycas, stating that 'a difficult and protracted task awaits any responsible monographer of the genus'.

Maconochie (1978) described two new taxa in Western Australia and the Northern Territory (C. pruinosa and C. calcicola), and later (1980) recognised the distinctive nature of C. angulata, C. armstrongii, C. basaltica and C. furfuracea in a summary contribution to a student text. The morphological studies by Chirgwin (1993 and unpub.) indicated that the Northern Territory occurrences were taxonomically complex, and led to description of one new taxon (C. conferta). My studies have addressed aspects of the cycads of Queensland and the Northern Territory, and have already recognised 10 additional species, six in Queensland and four in the Northern Territory (Hill 1992, 1993, 1994a).

\section{Species concepts}

The genus Cycas shows a complex geographic replacement pattern throughout its range in Australia, with many very closely related entities. The region of most complexity is the Northern Territory, where two series (see below) occur in a mosaic. The first is the $C$. armstrongii alliance, characterised by the spinescent cataphylls, the non-recurved margins of the pinnae and the reduced hypodermis. This group comprises $C$. armstrongii, $C$. conferta, $C$. orientis, and C. canalis from the Northern Territory, C. lane-poolei from Western Australia, C. xipholepis from Queensland and C. papuana from the Western Province of New Guinea. The second is the C. calcicola group, with soft cataphylls and pinnae with recurved or revolute margins and continuous hypodermis, comprising and C. arenicola, C. arnhemica, C. calcicola and C. maconochiei. Other characters such as the dense orange tomentum shared by C. lane-poolei, C. canalis and C. maconochiei suggest, however, that these species may be closer to each other than each may be to other species with similar pinna margins. Although several of these taxa are similar in many respects, the homoplasy evident in these characters does not always allow unequivocal aggregation into groups that could be treated as species with subordinate subspecies. In order to satisfactorily separate and recognise groups of populations which show real, albeit sometimes small, differences, many of the taxa are treated herein as distinct species. This rather narrow view of species is considered preferable to the arbitrary submerging of these 
recognisably distinct and true-breeding groups of populations into broader and less meaningful 'species', and the consequent loss of information on the real diversity of these plants. The rank of subspecies is used in other cases where clearly defined species show a consistent pattern of geographic variation, but the pattern shows a clinal transition from one area to another. Subspecies are also recognised in some disjunct examples where clinal transition is lacking, but the overall species is coherent and the degree of regional variation limited.

Species definition is complicated by the variability of some of the characters that have been traditionally used to separate taxa. Development of spines on petioles is often variable within populations, and often changes with age in most taxa in Australia. Microsporophylls vary considerably in size and shape from base to apex of the cone, in particular, the apical spine is reduced or absent on the lowermost sporophylls, gradually increasing in size towards the apex or towards the centre of the cone (see also Amoroso 1986). Megasporophylls also vary in size, shape of lamina, and number of ovules. This can depend on their position within a growth flush, the first and last produced often being markedly smaller and less elaborate than those in the centre. Surveys of all characters across several populations have been carried out for all taxa that have been studied in the field.

\section{Hybridism}

The problem of hybridism in Cycas has been introduced elsewhere (Hill 1992). The lack of pollinator specificity, when combined with the apparently weak inherent fertility barriers, results in the major reproductive barrier between $C y c a s$ species in nature being geographic separation. Natural populations of $C y c a s$ species are usually widely separated geographically, and some breakdown of reproductive isolation would therefore be expected where different species have spread to within pollination range of each other.

A number of naturally occurring populations are postulated to be of just such hybrid origin. These are morphologically intermediate between the putative parent species and also show the high degree of variability to be expected from Mendelian segregation in second and later generations. Hybrid or intergrading populations have been recorded from throughout the range of Cycas in Australia, wherever different species grow in relatively close proximity. These include hybrids between $C$. armstrongii and $C$. conferta, C. armstrongii and C. maconochiei, C. calcicola and C. conferta, and C. arnhemica and C. orientis in the Northern Territory, C. basaltica and C. lane-poolei in Western Australia. In Queensland, hybrid populations occur between C. media and C. platyphylla, C. media and $C$. ophiolitica, and C. ophiolitica and C. megacarpa. Representative specimens from populations postulated to be of hybrid origin are cited in the appendix in alphabetical order of parent species. Representatives of transitional populations between subspecies of the same species are cited under the relevant species.

\section{Leaf structure}

Cycas displays features of leaf anatomy that are unique in the seed plants. Individual pinnae have a single longitudinal vein (or midrib) with a single vascular bundle, with no accessory or lateral veining. There is, however, a continuous layer of undifferentiated transfusion tissue lying between the upper and lower mesophyll layers and extending from the midrib almost to the leaf margin. This tissue is composed of mixed xylem-like and phloem-like cells which probably function as xylem and phloem in normal vascular tissue (see also Lamb 1923). 
This feature is constant in all species examined, but other details of leaf anatomy vary considerably, and allow recognition of a number of distinct groups within Cycas in Australia. The following differences have been observed (see Figs 1 \& 2):

1. Upper mesophyll is usually not continuous across the midrib, but may be in some species. This feature is also not constant in some species.

2. Lower mesophyll cells may be equidimensional or elongated and palisadelike, or somewhat intermediate between these two forms.

3. Lower mesophyll is usually not continuous across the midrib, but may be in some species. This feature is also not constant in some species.

4. Hypodermis (across the lamina, excluding the midrib and margin) may be continuous, interrupted or absent.

5. Hypodermis (when continuous) may be one, two or three cell layers thick.

6. Leaf margins may have single or multiple layers of hypodermis.

7. Stomatal subsidiary cells may be raised and thickened or undifferentiated from general epidermal cells.

8. Stomatal crypts may be shallow and open, or deep and restricted by overarching subsidiary or epidermal cells.

9. Cuticle varies considerably in thickness between species.

Anatomical differences are enumerated below in discussions of species or groups.

\section{Evolutionary considerations}

Suites of anatomical character states frequently correlate; for example, continuous hypodermis usually occurs together with thickened cuticle, recurved or revolute leaf margins and deeply encrypted stomata. This suite occurs in taxa from drier environments such as $C$. cairnsiana and $C$. pruinosa, presumably representing ecological adaptation to aridity. The basic state in Cycas is apparently more mesophyllous (see Hill 1996), and this suite of adaptations is thus apomorphic in several Australian groups.

Another apomorphic character in the Australian taxa is the development of palisade cells in the lower or abaxial mesophyll, a condition not seen in Cycas outside Australia. The interrupted upper and lower mesophyll conditions are also apparently apomorphic, although somewhat plastic and often variable within species within the Australian region.

The tendency towards similifaciality in the leaves of series Ammstrongianosae is also apomorphic, with this condition occurring only in that series, and the basic state in the genus being strongly dorsiventral.

\section{Taxonomic treatment}

The Australian species and some of the taxa from Papua New Guinea comprise section Cycas subsection Endemicae. Seven series are recognised within this section, five of them endemic in Australia. 


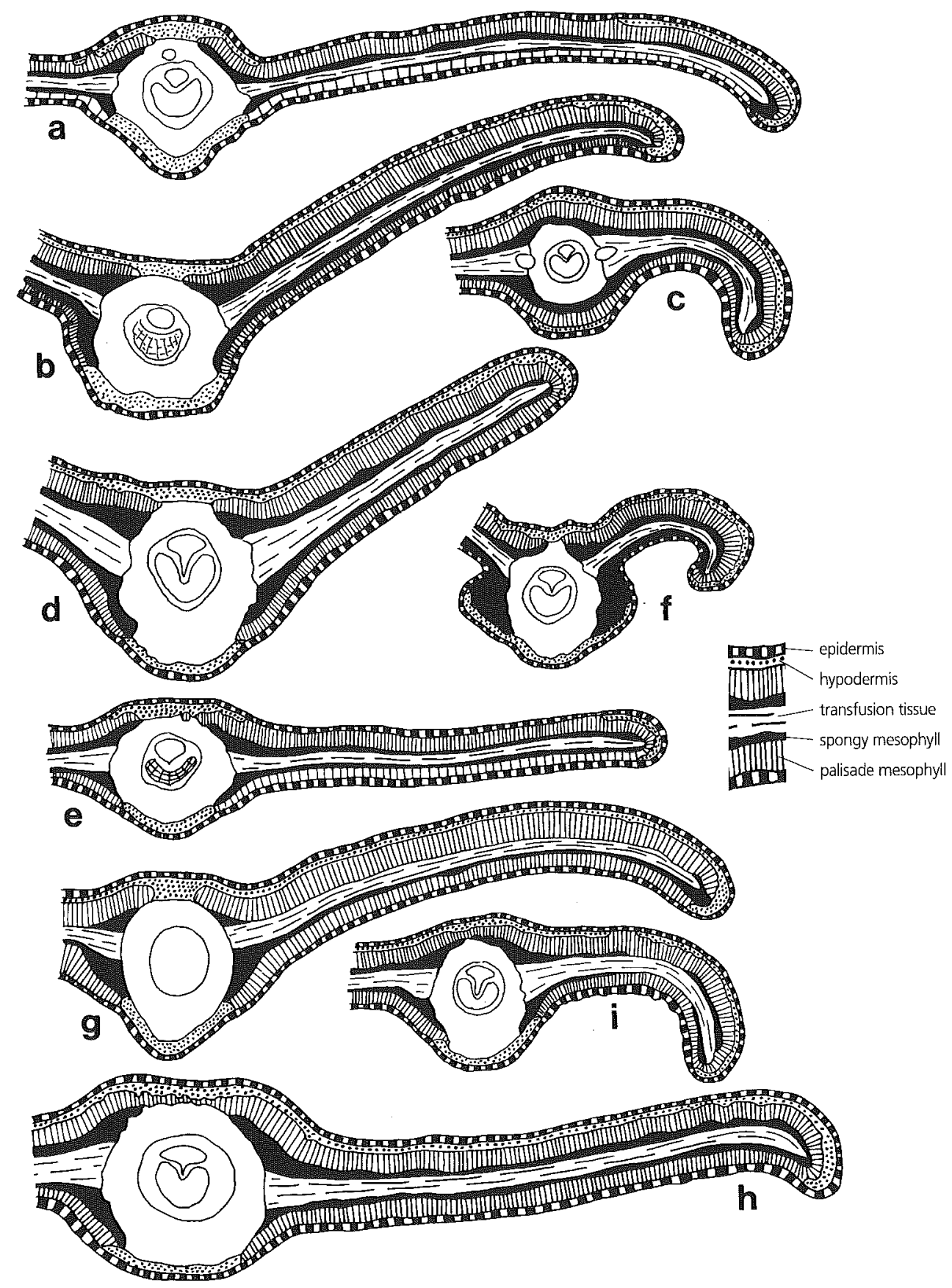

Fig. 1. Leaf sections. a, C. media subsp. ensata, Hind 2289 (series Endemicosae). b, C. tuckeri, Maconochie 2690 (series Yorkianosae). c, C. cairnsiana, Hill 3757 (series Caimnsianosae). d, C. angulata, Hill. 4132 (series Angulatosae). e, C. canalis subsp. carinata, Hill 4061 (series Armstrongianosae). f, C. arnhemica subsp. arnhemica, Maconochie 1471 (series Calcicolosae). g, C. calcicola, Hill 3967 (series Calcicolosae). h, C. furfuracea, Maconochie 1196 (series Furfuraceosae). i, C. pruinosa, Wilson 843 (series Furfuraceosae). 


\section{Section Cycas}

Section Lemuricae Schuster, Pflanzenr. 99: 65 (1932), nom. illegit.

Section Cycas is defined by the combination of glabrous ovules and a non-pectinate megasporophyll lamina. These characters are implicit in all species descriptions below. Three subsections are recognised, only one occurring in Australia (Hill 1994a).

Subsection Endemicae Schuster, Pflanzenr. 99: 65 (1932).

Type species: Cycas media R. Brown , Prodr.: 348 (1810), lectotype designated by Hill (1994b).

This subsection is distinguished by the relatively flattened microsporophylls with a short and sharply upturned apical spine, the lack of a spongy endocarp layer, and the lack of a fibrous layer in the sarcotesta. Pinnae are often pungent-acuminate, as stated by Schuster, but not in all species, and often no more so than in other groups. Seven series are recognised (see also Hill 1994a), five of them endemic in Australia, and two occurring in both Australia and New Guinea (Fig. 3). The total number of species now recognised in the section is 30, with 27 endemic in Australia, and three endemic in New Guinea. This makes it the largest infrageneric group within the genus, and makes Australia the richest area in number of species, although not in overall diversity at higher taxonomic levels.
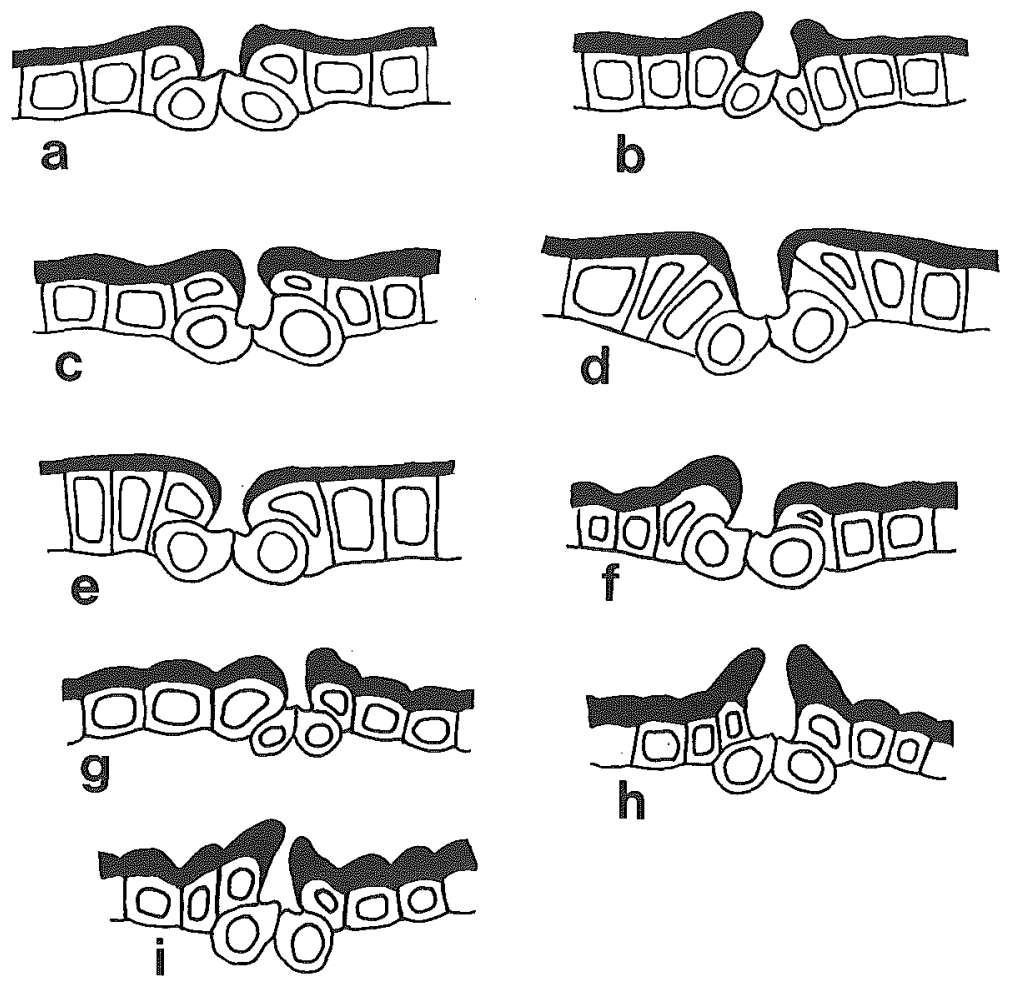

Fig. 2. Stomatal sections. a, C. media subsp. ensata, Hind 2289 (series Endenicosae). b, C. tuckeri, Maconochie 2690 (series Yorkianosae). c, C. caimsiana, Hill 3757 (series Caimsianosae). d, C. angulata, Hill 4132 (series Angulatosae). e, C. canalis subsp. carinata, Hill 4061 (series Arnstrongianosae). $\mathrm{f}, \mathrm{C}$. arnhentica subsp. arnhemica, Maconochie 1471 (series Calcicolosne). g, C. calcicola, Hill 3967 (series Calcicolosne). h, C. furfuracea, Maconochie 1196 (series Futfuraceosae). i, C. pruinosa, Wilson 843 (series Furfuraceosae). 

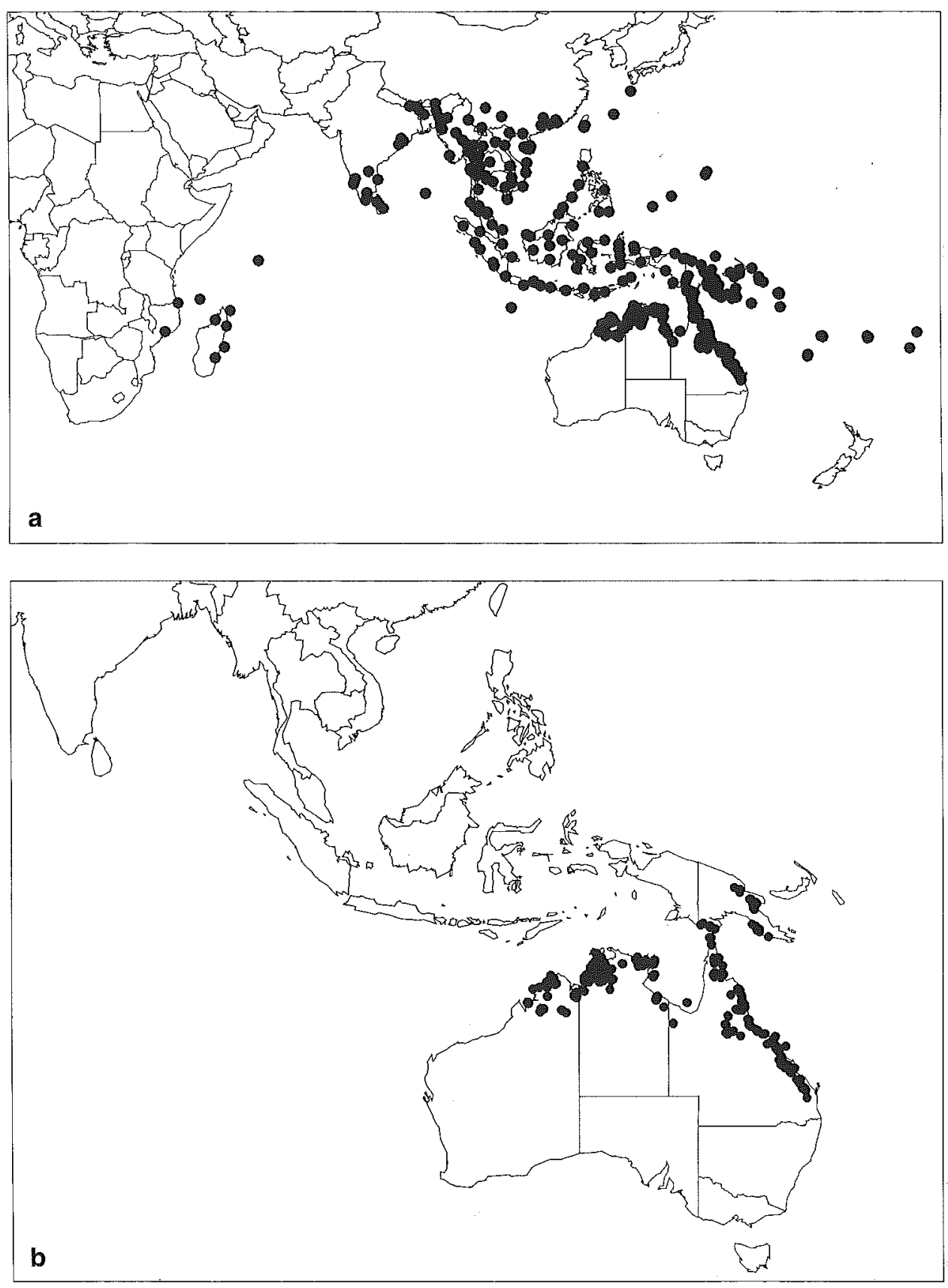

Fig. 3. Distribution of the genus Cycas (a), and subsection Endemicae (b). 


\section{Key to the series}

1 Basal pinnae gradually reducing in size

2 Basal pinnae reducing to spines; lateral megasporophyll teeth large, not pungent Series Furfuraceosae (species 25-27)

$2^{*}$ Basal pinnae not reducing to spines; lateral megasporophyll teeth small, pungent Series Calcicolosae (species 21 to 24)

$1^{*}$ Basal pinnae not gradually reducing in size

4 Hypodermis absent; leaf margins flat Series Armstrongianosae (species 15 to 20)

4* Hypodermis present; leaf margins recurved

5 Hypodermis interrupted; leaves green

6 Cataphylls strongly spinescent Series Endemicosae (species 1 to 4)

$6^{*}$ Cataphylls soft, not spinescent Series Yorkianosae (species 5 to 8 )

5* Hypodermis continuous; leaves grey or blue

7 Leaves strongly glaucous; male cones small to medium, ovoid

Series Cairnsianosae (species 9 to 12)

$7^{*}$ Leaves not strongly glaucous; male cones large, stibglobose

Series Angulatosae (species 13 and 14)

\section{Key to the Australian species}

1 Margins of pinnae revolute; pinnae narrow (mostly less than $4 \mathrm{~mm}$ wide)

2 Mature pinnae densely tomentose, at least beneath

3 Pinnae numerous (210-410), narrow (2.0-4.0 mm wide); crowded (spaced at 4-6 $\mathrm{mm}$ on rachis), abruptly tapered apically 24. C. calcicola

$3^{*}$ Pinnae not as numerous $(180-270)$, wider $(4.5-6.5 \mathrm{~mm}$ wide); not crowded (spaced at 9-14 mm on rachis), gradually tapered apically $\ldots$ 23. C. arenicola

2* Mature pinnae not densely tomentose

4 Microsporangiate cones fusiform, $>35 \mathrm{~cm}$ long 27. C. pruinosa

4* Microsporangiate cones ovoid to narrowly ovoid, $<30 \mathrm{~cm}$ long

5 Pinnae green 21. C. arnhemica

$5^{*}$ Pinnae glaucous

6 Cataphylls soft 10. C. cairnsiana

6* Cataphylls pungent

12. C. desolata

1* Margins of pinnae flat or recurved, pinnae not revolute; pinnae more than $4 \mathrm{~mm}$ wide

7 Midrib of pinnae equally prominent above and below; pinna margins flat and not distinctly thickened

8 New growth strongly glaucous

19. C. canalis

$8^{*}$ New growth green or bluish green

9 Pinnae concolorous, partly amphistomatic, crowded .... 17. C. conferta 
9* Pinnae more or less discolorous, hypostomatic, well-spaced on rachis

10 Stem less than $12 \mathrm{~cm}$ diam.; seeds less than $38 \mathrm{~mm}$ long; cataphylls finely orange- and grey-tomentose

18. C. armstrongii

$10 *$ Stem more than $12 \mathrm{~cm}$ diam.

11 Cataphylls densely orange-woolly or floccose .... 20. C. lane-poolei

$11^{*}$ Cataphylls shortly pale brown-tomentose

15. C. xipholepis

$7^{*}$ Midrib of pinnae not prominent above, very prominent below; pinna margins slightly to distinctly recurved, distinctly thickened

13 Basal pinnae progressively reduced in size

14 Ultimate basal pinnae merging into spines

15 Leaves keeled (included angle between opposing pinnae $135^{\circ}$ or less); pinnae inserted at $40-60^{\circ}$ on rachis 25. C. furfuracea

$15^{*}$ Leaves flat (included angle between opposing pinnae inserted $\left.150-180^{\circ}\right)$; pinnae inserted at $60-90^{\circ}$ on rachis

26. C. basaltica

$14^{*}$ Ultimate basal pinnae clearly separated from spines

16 Crown and cataphylls densely orange-woolly or floccose

22. C. maconochiei

$16^{*}$ Crown and cataphylls shortly grey and orange-tomentose

21. C. arnhemica

$13^{*}$ Basal not pinnae progressively reduced in size

17 Leaves keeled

18 Cataphylls hard, pungent

19 Stems slender (<15 cm diam.); leaves short (70-110 cm long); cataphylls short (to $7 \mathrm{~cm}$ long)

3. C. megacarpa

$19 *$ Stems thick (> $17 \mathrm{~cm}$ diam.); leaves long (110 cm long or usually longer); cataphylls long ( $7 \mathrm{~cm}$ long or usually longer)

20 Pinnae up to $6 \mathrm{~mm}$ wide, margins distinctly recurved

14. C. angulata

$20^{*}$ Pinnae more than $6 \mathrm{~mm}$ wide, margins slightly recurved $\ldots$ 13. C. brunnea

$18^{*}$ Cataphylls soft, not pungent

21 New growth glaucous

22 New growth with mainly white or grey trichomes

11. C. couttsiana

$22^{*}$ New growth with mostly brown or orange trichomes

23 Pinnae $6.0-7.5 \mathrm{~mm}$ wide; leaves keeled at $80-120^{\circ}$

8. C. ophiolitica

$23^{*}$ Pinnae $4.6-6.0 \mathrm{~mm}$ wide; leaves keeled at $45-60^{\circ}$

9. C. platyphylla

$21^{*}$ New growth green

24 Crown and cataphylls densely orange-woolly or floccose 
25 Megasporophyll apex 60-100 mm long, with 24-32 lateral spines 3-6 mm long, apical spine 12-16 mm long 4. C. yorkiana

25* Megasporophyll apex 50-55 mm long, with 22-24 lateral spines 1-4 mm long, apical spine 21-25 mm long

5. C. badensis

$24 *$ Crown and cataphylls very shortly grey to white-sericose

26 Megasporophylls short $(10-12 \mathrm{~cm})$; apex dilated (38-50 mm wide) ..................................... 6. C. tuckeri

$26^{*}$ Megasporophylls longer $(13-20 \mathrm{~cm})$; apex not dilated (20-28 mm wide)

7. C. semota

$17^{*}$ Leaves flat

27 Pinnae $10 \mathrm{~mm}$ wide or wider; cataphylls deciduous $\quad \ldots \quad$ 1. C. silvestris

$27^{*}$ Pinnae $<9 \mathrm{~mm}$ wide; cataphylls persistent

28 Pinnae brown-tomentose beneath

23. C. arenicola

$28^{*}$ Pinnae glabrous beneath

29 Pinna margins slightly to moderately recurved .... 2. C. media

$29 *$ Pinna margins flat

16. C. orientis

\section{Series Endemicosae}

Type species: Cycas media R. Br.

Leaves openly keeled (opposing ranks of pinnae arranged at an angle of more than $120^{\circ}$ ) to almost flat; basal pinnae not gradually reducing to spines; cataphylls hard, pungent; microsporangiate cone medium-size, ovoid, yellow- to orange-brown; megasporophyll lamina narrowly to broadly triangular, lateral teeth to $10 \mathrm{~mm}$ long, pungent. Upper mesophyll usually continuous, sometimes interrupted at midrib, with a distinct basal layer of equidimensional cells; lower mesophyll interrupted at midrib, composed of equidimensional, elongated or palisade cells; laminar hypodermis absent or scant, discontinuous; stomatal crypts shallow, open; subsidiary cells undifferentiated; cuticle thin.

A series of 3 species, ranging down the east coast of Australia from eastern Cape York Peninsula to south-eastern Queensland (Fig. 4).

1. Cycas silvestris K.D. Hill, Telopea 5(1): 181 (1992).

Type: Queensland: Cook District: c. $0.75 \mathrm{~km} \mathrm{NW}$ of Bolt Head, J. Clarkson $8813 \mathcal{E}$ J. Neldner, 14 July 1990 (holo NSW; iso BRI, MBA).

Illustration: Hill (1992: 182, Fig. 1).

See Hill (1992) for full description and specimen citations.

Leaf anatomy: upper mesophyll continuous or interrupted at midrib, composed of palisade and equidimensional cells; lower mesophyll interrupted at midrib, composed of equidimensional cells only; laminar hypodermis absent; marginal hypodermis 2 cell layers thick; stomatal crypts shallow, open; subsidiary cells undifferentiated; cuticle thin. 
Notes: distinguished from other Australian species by the broader and relatively thinner adult pinnae. A striking qualitative distinction not previously recorded is the smooth trunk, resulting from the shedding of leaf bases and cataphylls more than about 4 years old. These organs are retained throughout in C. media and other species in this subseries.

The broad, falcate pinnae and the non-pectinate megasporophyll apex with a distinct apical spine are similar to those of the complex surrounding C. rumphii Miq., which comprises an unknown number of taxa ranging from Sri Lanka and East Africa to Fiji and Tonga. Seeds, however, lack the spongy layer present in the C. rumphii complex (Dehgan \& Yuen 1983, Hill 1994). C. silvestris also differs from superficially similar taxa on South Pacific Islands (C. seemannii A. Br.) in the strongly spinose petiole (the Pacific Island plants have no or rarely few spines on petioles) and the markedly smaller seeds. Three taxa in the C. rumphii group are known from Papua New Guinea (Hill 1994), all of which differ from $C$. silvestris in the large seeds with spongy endocarp. Early reports of C. rumphii from Queensland refer to C. silvestris (Bailey 1913).

Distribution: $C$. silvestris is known only from subcoastal forests near the north-eastern tip of Cape York Peninsula, near Temple Bay and to the north and south of the Olive River estuary (Fig. 4). These quite rich and complex rainforests and Melaleucadominated forests occur on white siliceous old beach-dune sands, and this cycad appears to be endemic to that substrate.

Conservation status: $2 \mathrm{~V}$-. This taxon is known from a few small stands that are not adequately reserved.

2. Cycas media R. Brown, Prodr.: 348 (1810).

Type: Queensland: Calder Island, R. Brown (holo BM; iso K).

See Hill (1992) for notes on typification.

Leaf anatomy: upper mesophyll interrupted at midrib, composed of palisade and equidimensional cells; lower mesophyll interrupted at midrib, composed of equidimensional and partly elongated cells; laminar hypodermis discontinuous, 1 cell layer thick when present; marginal hypodermis 2 cell layers thick; stomatal crypts shallow, open; subsidiary cells undifferentiated; cuticle thin.

Notes: distinguished from other Australian species by the glabrous, glossy green leaves with more or less flat pinnae, and the relatively small seeds. The similar $C$. silvestris has broader pinnae and a smooth trunk, and the similar C. megacarpa has usually shorter, more strongly keeled leaves with fewer pinnae, larger seeds, and a more slender trunk. Plants from near-coastal sites in the Cooktown district and north of there have wider and more distinctly falcate pinnae and smaller seeds. An isolated population on the east coast of Cape York Peninsula near the Rocky River estuary is distinguished by much longer cataphylls. These variants are recognised below as subspecies.

Distribution: widespread and locally common in open or closed forest or occasionally rainforest in eastern Queensland, from south of Mackay to coastal Cape York Peninsula, east of Coen (Fig. 4).

\section{Key to the subspecies}

1 Pinnae 5-7 $\mathrm{mm}$ wide, margins distinctly recurved 2A. subsp. media

1 * Pinnae 7-10 mm wide, margins slightly recurved

2 Longest cataphylls more than $100 \mathrm{~mm}$ long 2B. subsp. ensata

2* Longest cataphylls less than $90 \mathrm{~mm}$ long 2C. subsp. banksii 
2A. Cycas media subsp. media

Cycas gracilis Miquel, Versl. K. Acad. Wet. Amsterdam 15: 366 (1863).

Type: Queensland, near Cape Upstart, F. Mueller (holo U 028108, photo seen).

Cycas normanbyana F. Mueller, Fragm. 8: 169 (1874).

Cycas rumphii Miq. subsp. normanbyana (F. Mueller) Schuster, Pflanzenr. 99: 75 (1932).

Type: Queensland: Port Denison, E. Fitzalan, Apr 1874 (holo MEL 68048, photo seen).

Cycas gracilis Miquel var. glauca Regel, Act. Hort. Petropol. 4: 282 (1876).

Type: probably from cultivated material in collections of or supplied by the following collectors (not seen). These were cited by Regel as 'C. media h. Van Houtte. - C. Boddami h. Haage et Schm. - Macrozamia latifrons h. Bull. - C. Normanbyana h. Belg.'

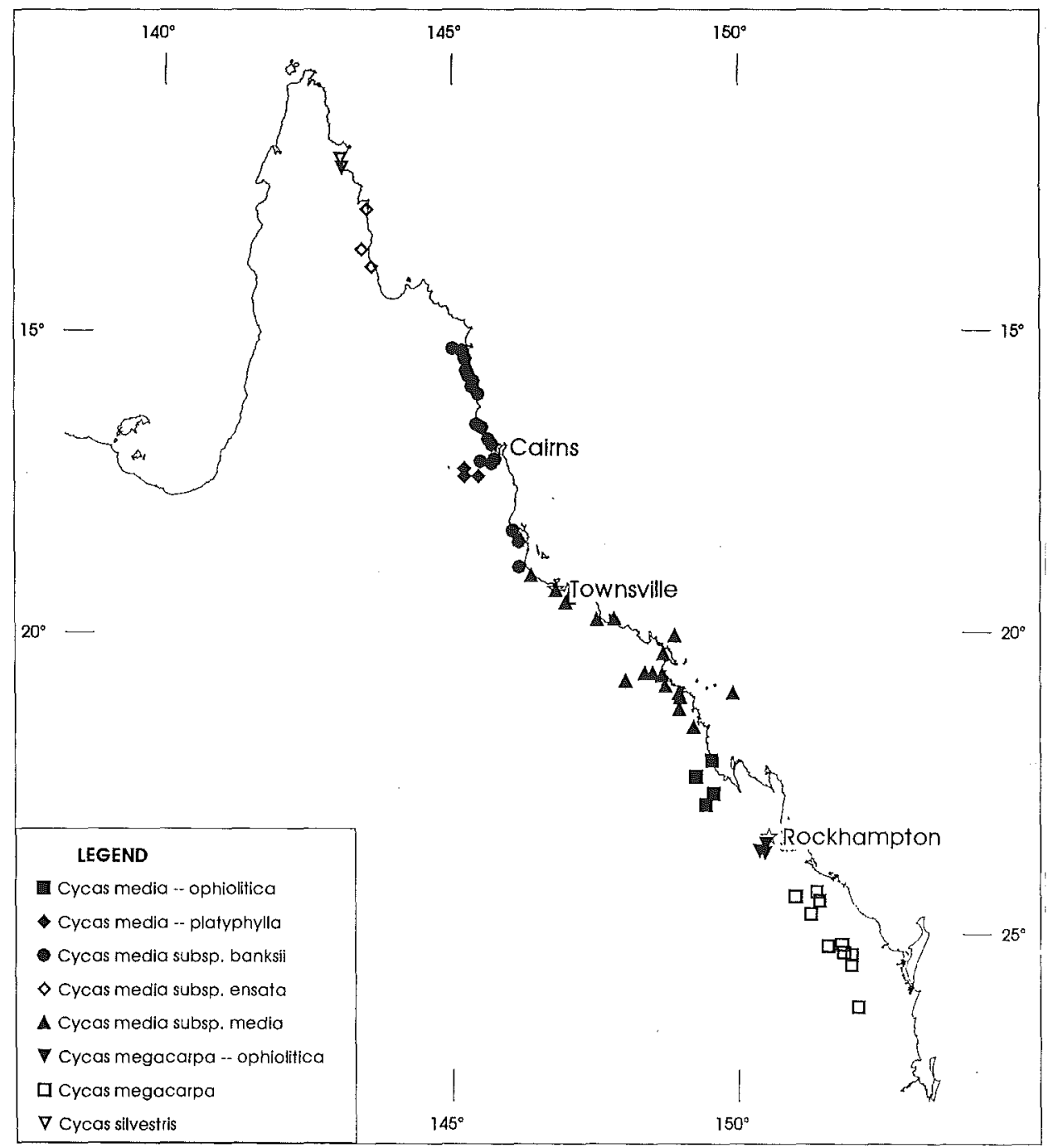

Fig. 4. Distribution of series Endemicosae (see Fig. 12, p. 25, for distribution of C. ophiolitica and C. platyphylla). 


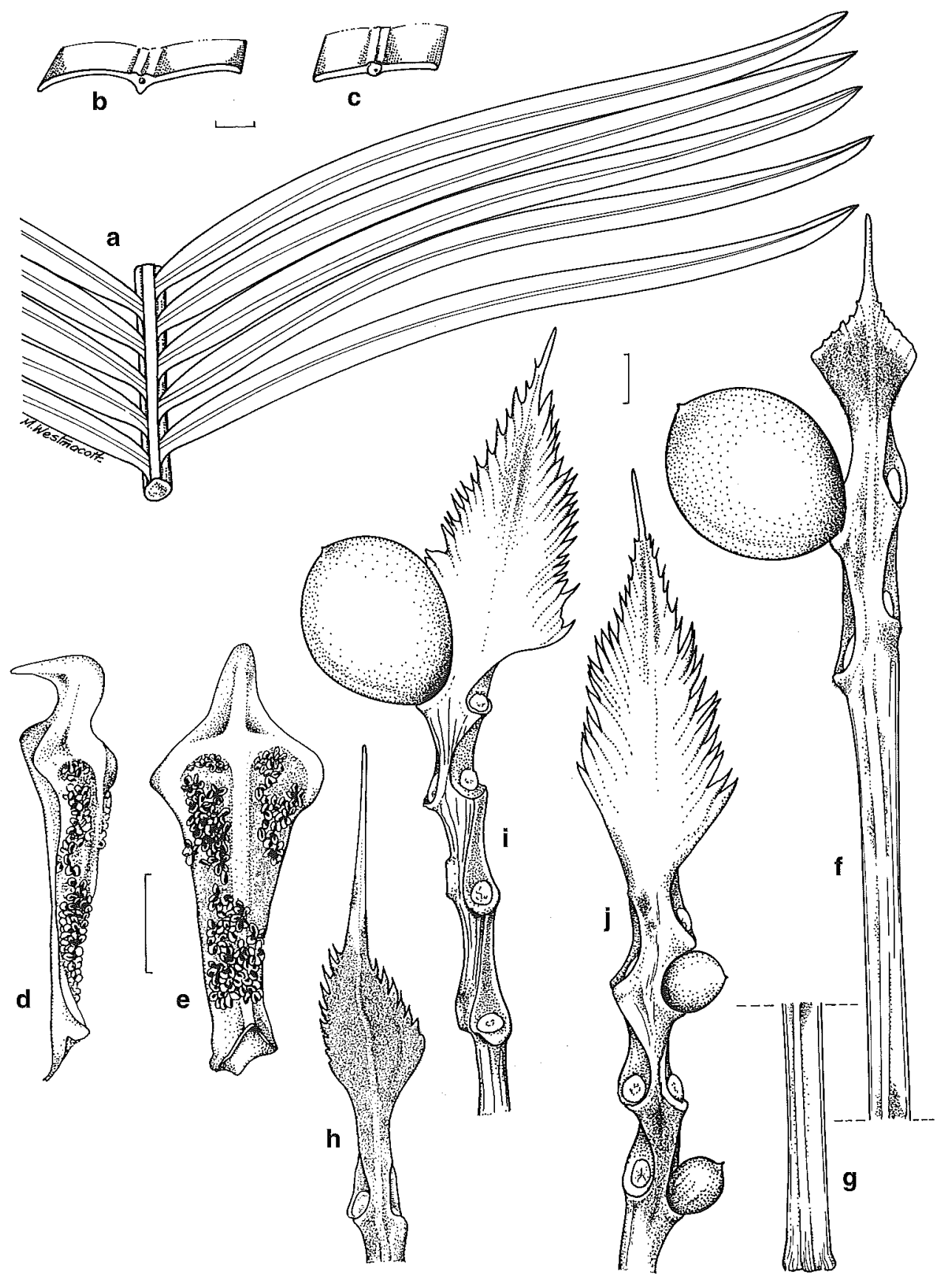

Fig. 5. Cycas media subsp. media. a, part of leaf. c, section of pinna. d, e, microsporophyll. $\mathbf{f}, \mathbf{g}$, megasporophyll with seed and stipe (in two sections). $\mathbf{h}, \mathbf{i}, \mathbf{j}$, tips of different megasporophylls (a, c, h from Hill 3713; d, e, f, g from Hill 3711; j from Hill 3785). Cycas media subsp. banksii. b, section of pinna. $i$, tip of megasporophyll (b, i from Hill 3777 ). Scale bar: $a=1 \mathrm{~cm}, b, c=2 \mathrm{~mm} ; \mathrm{d}-\mathrm{i}=1 \mathrm{~cm}$. 
Cycas gracilis Miquel var. viridis Regel, Act. Hort. Petropol. 4: 282 (1876).

Type: probably from cultivated material in collections of or supplied by the following collectors (not seen). These were cited by Regel as 'C. gracilis h. Paull. - C. Riumiana h. Turic. Habitat in Nova Hollandia tropica.'

Cycas kennedyana F. Mueller, Australas. Chem. Drugg. 4(47): 85 (1882).

Type: Queensland, Port Denison, E. Fitzalan, 1881 (syn MEL 68039, 68044, photos seen). Illustration: Hill (1992: 186, Fig. 3a, c-h, j).

Leaves 70-180 cm long; median pinnae 130-210 $\mathrm{mm}$ long, 5-7 mm wide, margins distinctly recurved. Longest cataphylls $60-90 \mathrm{~mm}$ long. Seeds $34-39 \mathrm{~mm}$ long, $32-35 \mathrm{~mm}$ wide. Fig. 5.

Notes: the names C. kennedyana and C. nommanbyana have been widely applied to forms of C. media subsp. media, and also erroneously to two other Queensland species from south of the range of C. media. The diagnostic features of these 'taxa' as originally described occur at random through most populations of $C$. media subsp. media. Typification of these taxa has been discussed previously (Hill 1991).

Distribution: locally abundant in coastal eucalypt forests, from around Cardwell south to around St Lawrence (Fig. 4). This subspecies is usually found on sites that offer good soil drainage, often on sandy soils and on sloping sites.

Conservation status: not considered to be at risk.

Selected specimens: Queensland: $40 \mathrm{~km}$ S of Ingham, Maconochie 2733, 24 June 1981 (DNA, BRI, NSW); Storth, Hill 3713 \& Stanberg, 25 July 1990 (NSW); Cape Upstart, SW side, Hill 3711 \& Stanberg, 25 July 1990 (NSW); track over Normanby Range on Mt Hector station, Hill 3784, 3785 \& Stanberg, 6 Aug 1990 (NSW, BRI); $1 \mathrm{~km} \mathrm{~S}$ of Kuttabul road on Seaforth-Mackay road, Hind 2869 A \& B, 29 Dec 1980 (NSW); c. 13 km S of Clareview on Bruce Highway, Hind 2858, 25 Dec 1980 (NSW).

Intergrades, subsp. media - subsp. banksii

Queensland: Cook: 5 miles [8 km] from Gordonvale on Atherton road, Briggs 1971, 3 Aug 1968 (NSW); crest of Herberton Range on. Atherton-Herberton road, Hill 3768 E Stanberg, 1 Aug 1990 (NSW).

\section{B. Cycas media subsp. ensata K.D. Hill, subsp. nov.}

A subspecie typica pinnis latioribus marginibus minus recurvis, seminibus minor, differt. A subspecie banksii cataphyllis longioribus, differt.

Type: Queensland: Rocky River track, $24.9 \mathrm{~km}$ N of Silver Plains homestead, K.D. Hill 4686 \& L. Stanberg, 8 Jul 1994 (holo NSW; iso BRI, CANB, DNA, K, L, NY)

Leaves 140-230 cm long; median pinnae 130-240 mm long, 7.5-9 mm wide. Longest cataphylls 100-120 mm long. Seeds 33-36 mm long, 29-32 mm wide. Fig. 6.

Distinguished by the very long, hard and sharp cataphylls.

Distribution: known from the coastal plain north of Silver Plains homestead, apparently extending as far north as Lockhart River (Fig. 4). Locally abundant in tall eucalypt forest-rainforest ecotonal areas with Livistona muelleri on flat country, on deep alluvial sandy soil.

Conservation status: locally abundant and isolated, not considered to be greatly at risk, but warranting a status code of $2 \mathrm{R}$ - at least until a more comprehensive survey of the occurrence can be conducted. 
Etymology: the epithet is from the Latin ensatus, a sword, in reference to the unusually long and sharp cataphylls.

Selected specimens: Queensland: Cook: $1 \mathrm{~km} \mathrm{~W}$ of Lockhart, Harris 81, 6 Oct 1974 (DNA, BRI); Rocky River, Timber Reserve 14, Stocker 1051, 7 Sep 1973 (QRS, BRI); Rocky River track, 24.9 km N of Silver Plains homestead, Hill 4687 \& Stanberg, 8 Jul 1994 (NSW); c. $29 \mathrm{~km} \mathrm{~N}$ of Silver Plains homestead on track to Rocky River, Hind 2288, 2289, 14 Aug 1978 (NSW).

2C. Cycas media subsp. banksii K.D. Hill, subsp. nov.

$\mathrm{Ab}$ subspecie typica pinnis latioribus marginibus minus recurvis, seminibus minor, differt. Ab subspecie ensata cataphyllis brevioribus, differt.

Type: Queensland: Hopevale turnoff, on Cooktown to Battle Camp road, K.D. Hill 4721 $\mathcal{E}$ L. Stanberg, 15 Jul 1994 (holo NSW; iso BRI, CANB, DNA, K, L, MEL, NY)

Illustration: Hill (1992: 186, Fig. 3b, i).

Leaves 100-200 cm long; median pinnae 130-240 $\mathrm{mm}$ long, 7-10 mm wide, margins slightly recurved. Longest cataphylls $70-100 \mathrm{~mm}$ long. Seeds $31-36 \mathrm{~mm}$ long, $26-32 \mathrm{~mm}$ wide. Fig. 5.

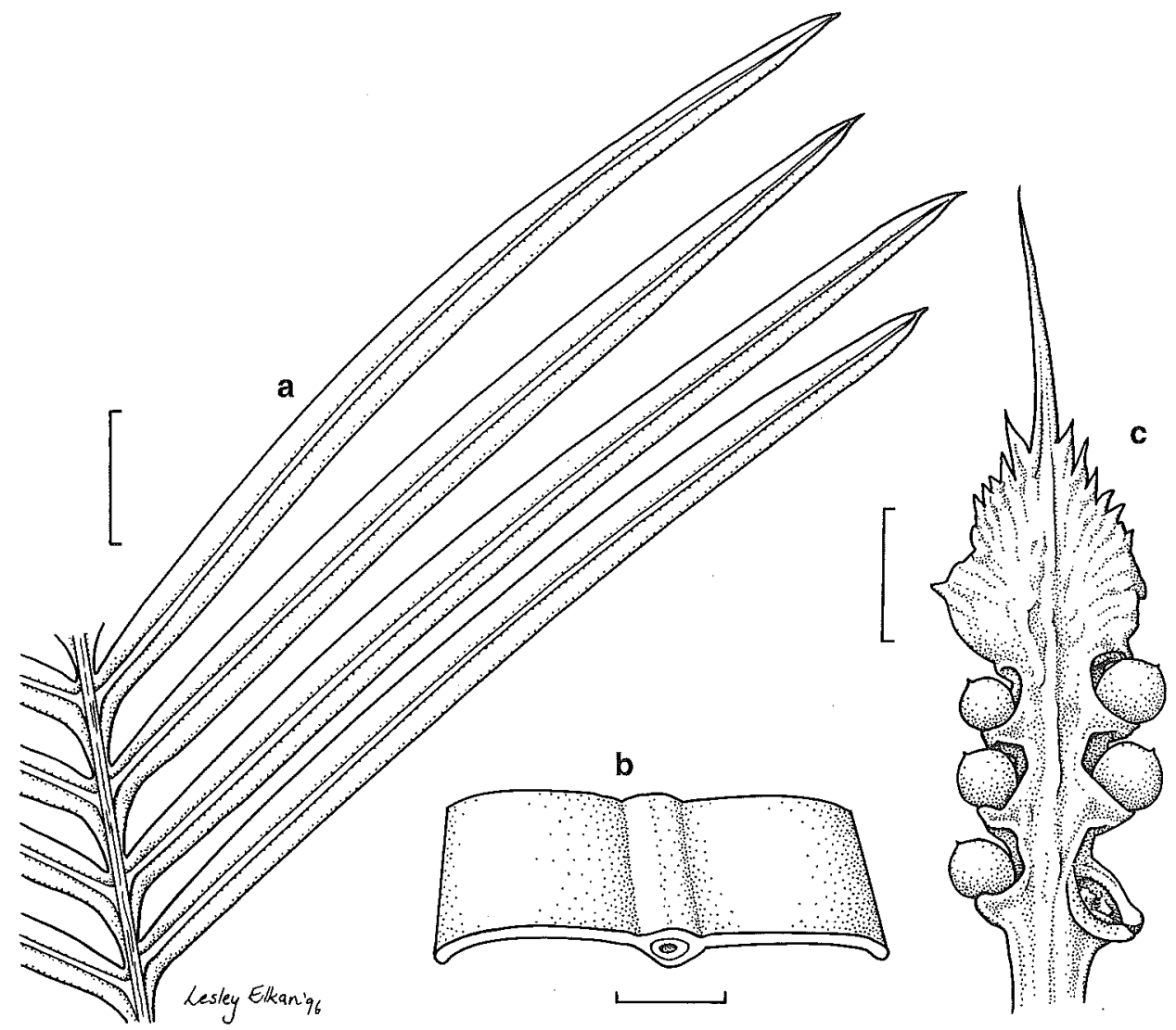

Fig. 6. C. media subsp. ensata. a, part of leaf. $\mathbf{b}$, section of pinna. $\mathbf{c}_{\text {, megasporophyll with ovules }}$ and stipe. Scale bar: $a, c,=1 \mathrm{~cm} ; \mathrm{b}=2 \mathrm{~mm}$. 
Distinguished from subsp. ensata by the shorter cataphylls and from subsp media by the relatively broad pinnae.

Distribution: abundant in near-coastal sites, usually in tall eucalypt forests, from north of Cooktown to south of Cairns (Fig. 4).

Conservation status: widespread and locally abundant, not considered to be at risk.

Etymology: the epithet commemorates Joseph Banks, botanist on Cook's first voyage, and first European to collect this taxon, at Endeavour River in 1770.

Selected specimens: Queensland: Cook: Banks \& Solander, 1770 (BM); base of Grassy Hill, Cooktown, Hill 3774 \& Stanberg, 2 Aug 1990 (NSW); $0.9 \mathrm{~km} \mathrm{~N}$ of Wujal Wujal (Bloomfield), Hill 3777 \& Stanberg, 3 Aug 1990 (NSW, BRI); 31 miles [c. $50 \mathrm{~km}$ ] N of Cairns, Byrnes $2422 a, 9$ Nov 1971 (DNA, NSW); 5 miles [8 km] from Gordonvale on Atherton road, Briggs 1971, 3 Aug 1968 (NSW); crest of Herberton Range on Atherton-Herberton road, Hill 3768 \& Stanberg, 1 Aug 1990 (NSW).

3. Cycas megacarpa K.D. Hill, Telopea 5(1): 188 (1992).

Type: Queensland: Port Curtis District: W side of Blackmans Gap, $20.9 \mathrm{~km}$ from Bruce Highway at Miriam Vale on Manypeaks road, K.D. Hill 4142 \& L. Stanberg, 1 Oct 1991 (holo NSW; iso BRI, CANB, DNA).

Illustration: Hill (1992: 189, Fig. 5).

See Hill (1992) for description and specimen citations.

Leaf anatomy: upper mesophyll continuous, composed of palisade and equidimensional cells; lower mesophyll interrupted at midrib, composed of equidimensional and palisade cells; laminar hypodermis absent to discontinuous, 1 cell layer thick when present; marginal hypodermis 1 cell layer thick; stomatal crypts shallow, open; subsidiary cells undifferentiated; cuticle thin.

Notes: distinguished from other Australian species by the keeled green leaves and the large seeds. Adult leaves are also generally smaller and more keeled, the trunk is more slender, and seeds are larger than those of the similar C. media.

C. megacarpa has been cultivated in Australia under the name C. kennedyana, but the type of the latter name belongs to $C$. media (which see).

Distribution: scattered and localised on clay-loam soils over various substrates, usually on sloping country in wet eucalypt forests or rainforests. This species ranges from near Mount Morgan south to near Goomeri in Queensland, occurring in locally more mesic microhabitats, becoming quite sporadic and occurring further inland in the south of the range (Fig. 4). Populations near Mt Morgan show extensive intergradation with C. ophiolitica, but also have larger seeds than more southerly occurring plants.

Conservation status: 3VC. Although locally abundant, the eucalypt forest habitat of this species is not well conserved, and there is considerable risk of habitat removal for forestry and pastoral activity.

Series Yorkianosae, K.D. Hill, ser. nov.

Inter series subsectionis Endemicae combinatione folia plana vel parum carinata; pinnae inferiores non spinescentes; cataphylla brevioria non pungentia; strobilus masculus grandis vel aliquantum grandis, ovoideus, fulvus vel ferrugineus; megasporophylli lamina anguste vel late triangulari dentata, dentibus pungentibus usque ad $5 \mathrm{~mm}$ longis, distinguitur. 
Type species: Cycas yorkiana K.D. Hill.

Leaves openly keeled to almost flat; basal pinnae not gradually reducing to spines; cataphylls soft, not pungent; microsporangiate cone medium-size to large, ovoid to elongate-ovoid, yellow- to orange-brown; megasporophyll lamina narrowly to broadly triangular, lateral teeth to $5 \mathrm{~mm}$ long, pungent. Upper mesophyll continuous or interrupted at midrib, with a distinct basal layer of equidimensional cells; lower mesophyll interrupted at midrib, with well-developed palisade cells; laminar hypodermis continuous, less frequently discontinuous, stomatal crypts shallow, open; subsidiary cells undifferentiated or weakly raised and differentiated; cuticle moderately thick.

A northern tropical series, with about 5 species, restricted in Australia to Cape York Peninsula, with two endemic species in New Guinea (Fig. 7).

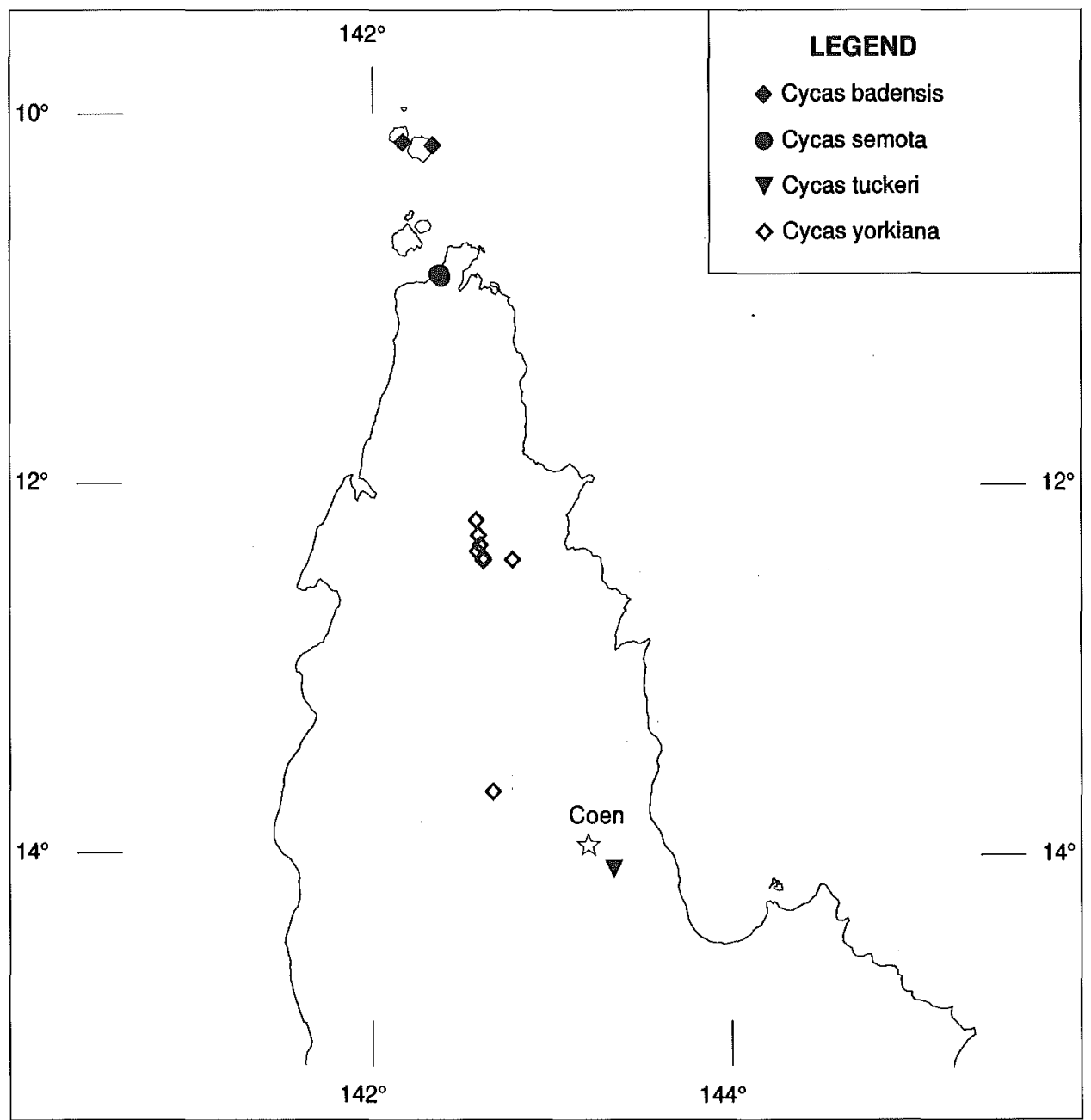

Fig. 7. Distribution of series Yorkianosne. 


\section{Cycas yorkiana K.D. Hill, sp. nov.}

Inter subsectionem Endemicae combinatione folia flavovirentia carinata, petiolis longioribus, pinnis carinatis et falcatis; cataphylla breviora non pungentia indumento floccoso, aurantiaco; sporophylla longiuscula, distinguitur.

Type: Queensland: $20.5 \mathrm{~km}$ N of Wenlock River crossing on Bamaga road, K.D. Hill 4711 \& L. Stanberg, 11 Jul 1994 (holo NSW; iso BRI, CANB, DNA, K, L, MEL, NY).

Stem to $1.5 \mathrm{~m}$ tall, rarely to $3.0 \mathrm{~m}, 14-20 \mathrm{~cm}$ diam. Leaves $90-140 \mathrm{~cm}$ long, openly keeled in section (opposing pinnae inserted at $150-180^{\circ}$ on rachis), with $160-220$ pinnae, terminated by a spine 5-20 mm long; petiole loosely orange-brown-woolly or floccose, $15-30 \mathrm{~cm}$ long; median pinnae at $60-75^{\circ}$ to rachis, $140-200 \mathrm{~mm}$ long, $5.5-7.5 \mathrm{~mm}$ wide, glabrous or loosely orange-woolly, glossy mid-green, usually falcate, keeled in section with recurved margins, decurrent for $3.0-5.0 \mathrm{~mm}$, narrowed to $4.0-5.0 \mathrm{~mm}$ at base (55-80\% of maximum width), spaced at $9-11 \mathrm{~mm}$ on rachis, apex attenuate; midrib slightly raised above, prominent below. New growth densely woolly with orangebrown trichomes. Cataphylls soft, 6-8 cm long, densely orange-brown-woolly or floccose. Pollen cones c. $20 \mathrm{~cm}$ long, c. 9 cm diam. Microsporophyll lamina c. $35 \mathrm{~mm}$ long, c. $12 \mathrm{~mm}$ wide, apical spine c. $6 \mathrm{~mm}$ long. Megasporophylls $20-32 \mathrm{~cm}$ long, grey- and orange-tomentose, with 2-6 ovules, sterile apex 60-100 mm long, 16-32 $\mathrm{mm}$ wide, narrowly triangular, regularly dentate, with 24-32 lateral teeth, apical spine 11-18 mm long, lateral teeth 3-6 mm long. Seeds flattened-ovoid, green becoming orange, not pruinose, 28-37 $\mathrm{mm}$ long, 26-32 $\mathrm{mm}$ diam.; sarcotesta 2-3 mm thick. Fig. 8 .

Leaf anatomy: upper mesophyll continuous, composed of palisade and equidimensional cells; lower mesophyll interrupted at midrib, composed of equidimensional and palisade cells; laminar hypodermis continuous, less often discontinuous, 1 cell layer thick when present; marginal hypodermis 2 cell layers thick; stomatal crypts shallow, open; subsidiary cells undifferentiated or raised and differentiated; cuticle thick.

Notes: distinguished from other Australian species by the bright green, keeled leaves with keeled and usually falcate pinnae, the short, soft cataphylls, and the thick crown of orange wool around the cataphylls. The closely allied C. badensis differs in having a smaller megasporophyll apex with fewer and shorter lateral spines and a shorter terminal spine, somewhat less orange wool in the crown, and pinnae that are usually straight rather than falcate. C. campestris from New Guinea has similar keeled pinnae, but also rarely falcate, and with narrower bases. The latter species is also distinguished by the broader megasporophyll lamina with longer lateral teeth (see Hill 1994). The orange wool around the cataphylls is not present in most other species in this group, but occurs in a number of other more distantly related species such as $C$. cairnsiana, C. ophiolitica, C. maconochiei and C. lane-poolei.

Distribution: extremely abundant in northern Cape York Peninsula, but apparently very localised within an area lying to the north of the Wenlock River (Fig. 7). A single specimen apparently from Rokeby (Gordon s.n.) belongs to this species, although this would be from within the range of C. xipholepis. C. yorkiana usually occurs as an understorey plant in open Eucalyptus miniata - E. tetrodonta forest on flat country, on sandy soils over laterite.

Conservation status: abundant but localised, not considered to be at risk, but the localised distribution warrants a code of $2 \mathrm{R}$.

Etymology: the epithet refers to the occurrence of this taxon in Cape York Peninsula.

Selected specimens: Queensland: Cook: $31 \mathrm{~km}$ N of Wenlock River crossing on Bamaga road, K.D. Hill 4710 \& L. Stanberg, 11 Jul 1994 (NSW); $3.8 \mathrm{~km} \mathrm{~N}$ of Moreton telegraph station, Hill 1779, 

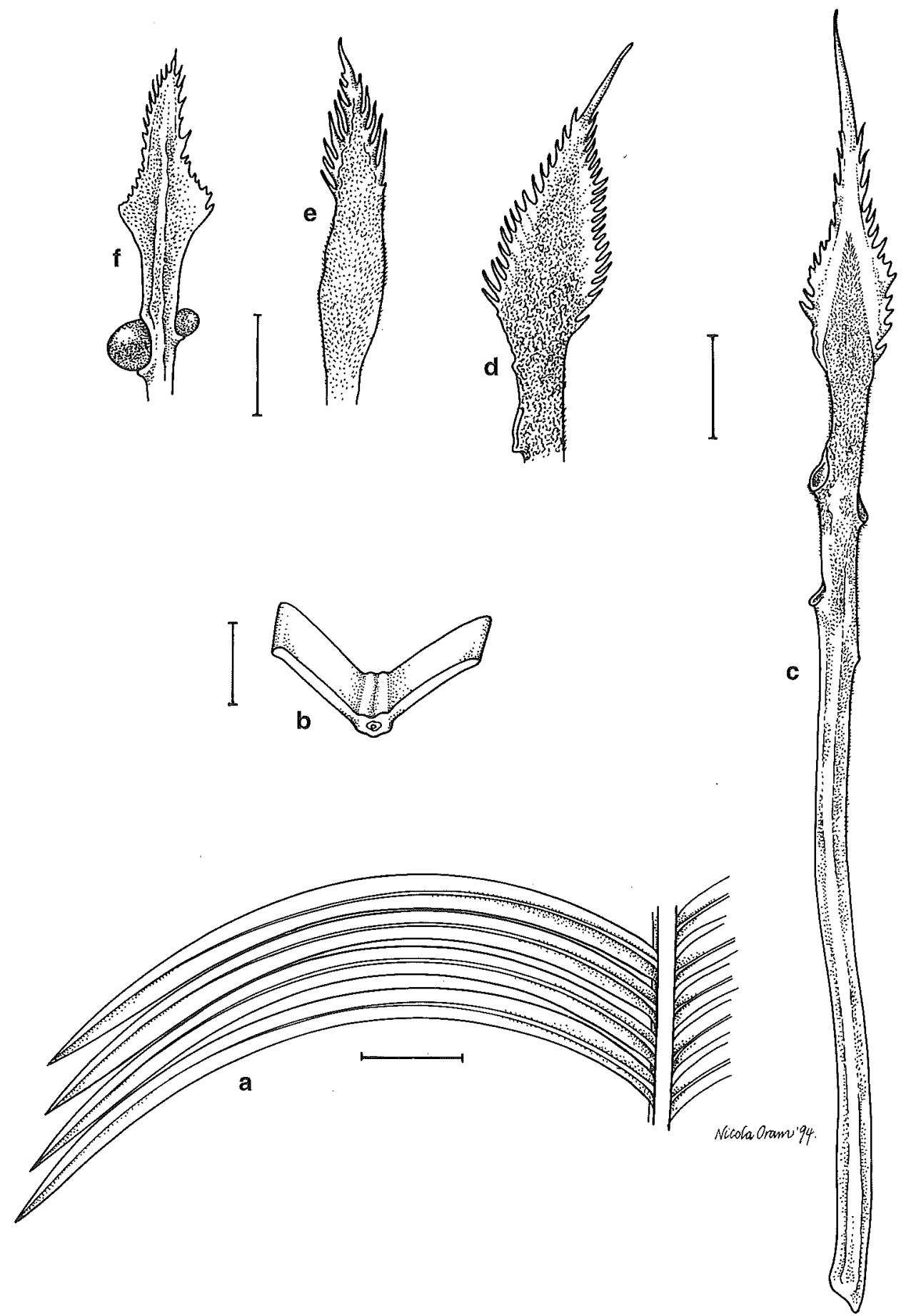

Fig. 8. C. yorkiana. a, part of leaf. $b$, section of pinna. $c$, megasporophyll with stipe, $d, e, f$, tips of megasporophylls ( $a, b, d, e, f$ from Hill 4711, c from Maconochie 2692). Scale bar: $a, c, d, e=1 \mathrm{~cm}$; $\mathrm{b}=2 \mathrm{~mm}$. 
22 July 1986 (NSW); $12 \mathrm{~km} \mathrm{~N}$ of Morton Telegraph station, Maconochie 2692, 2693, 16 Jun 1981 (DNA); $5.7 \mathrm{~km} \mathrm{~N}$ of Wenlock River on Peninsula Development Road, Clarkson 5651, 3 Nov 1984 (BRI, DNA); Rokeby, 45 miles [c. 72 km] NW of Coen, Gordon s.n., Oct 1966 (BRI).

\section{Cycas badensis K.D. Hill, sp. nov.}

Inter subsectionem Endemicae combinatione folia magna atroviridia carinata, pinnis carinatis latis; cataphylla breviora non pungentia; sporophylla longiuscula, distinguitur.

Type: Queensland: Badu Island, J.R. Clarkson 4007, 29 Oct 1981 (holo: BRI; iso: DNA).

Stems to $8 \mathrm{~m}$ tall. Leaves $100-120 \mathrm{~cm}$ long, moderately keeled, usually terminated by a spine, with $200-230$ pinnae; petiole $24-26 \mathrm{~cm}$ long (20-25\% of total leaf length), glabrous, unarmed or spinescent, for $5-50 \%$ of length. Basal pinnae not gradually reducing to spines, pinna $60-140 \mathrm{~mm}$ long. Median pinnae $110-220 \mathrm{~mm}$ long, 5-7.5 mm wide, glabrous, semiglossy mid to dark green, strongly discolorous, inserted at 50-70 degrees to rachis, section slightly keeled, margins slightly recurved, decurrent for $3 \mathrm{~mm}$, narrowed to $3-4 \mathrm{~mm}$ at base (to $50-60 \%$ of maximum width), spaced at 8-9 mm on rachis; apex acute, spinescent; midrib flat above, raised below. New growth loosely tomentose with orange-brown trichomes. Cataphylls narrowly triangular, soft, 50-90 mm long densely orange-woolly or floccose. Microsporangiate cones not seen. Microsporophyll lamina c. $40 \mathrm{~mm}$ long, c. $15 \mathrm{~mm}$ wide, fertile zone c. $25 \mathrm{~mm}$ long, sterile zone c. $15 \mathrm{~mm}$ long, level, apical spine prominent, sharply upturned, c. $4 \mathrm{~mm}$ long. Megasporophylls $23-28 \mathrm{~cm}$ long, brown-tomentose, with 4-6 ovules, sterile apex triangular, 50-55 mm long, 15-30 mm wide, regularly dentate, with 22-24 pungent lateral spines 1-4 mm long, 1-2 $\mathrm{mm}$ wide; apical spine distinct from lateral spines, 21-25 mm long, $5 \mathrm{~mm}$ wide at base. Seeds flattened-ovoid, 30-35 mm long, 27-29 $\mathrm{mm}$ wide, orange-brown, not pruinose. Fig. 9.

Notes: nearest to C. yorkiana, from which it differs in the smaller megasporophyll apex with fewer and shorter lateral spines and a shorter terminal spine, and somewhat less orange wool in the crown. Distinguished within the subsection by the short, soft cataphylls, the large leaves with broad pinnae, and the long megasporophylls.

Selected specimens: Queensland: Cook: Badu Island, Harris 130, 2 Nov 1974 (DNA).

\section{Cycas tuckeri K.D. Hill, sp. nov.}

Inter subsectionem Endemicae combinatione megasporophylla brevissima lamina lata, comparate breviore; cataphylla breviora non pungentia indumento brevissimo, adpresso, distinguitur.

Type: Queensland: Coen district, K.D. Hill 4683 \& L. Stanberg, 7 Jul 1994 (holo NSW; iso BRI, CANB, DNA, K, L, MEL, NY).

Stem to $4.0 \mathrm{~m}$ tall, rarely to $6.0 \mathrm{~m}, 16-24 \mathrm{~cm}$ diam. Leaves $90-150 \mathrm{~cm}$ long, openly keeled in section (opposing pinnae inserted at $90-140^{\circ}$ on rachis), with $100-200$ pinnae, sometimes terminated by a spine $2-5 \mathrm{~mm}$ long; petiole loosely orange-brown-tomentose, 20-45 cm long. Median pinnae 150-250 mm long, 7.0-9.0 $\mathrm{mm}$ wide, glabrous or loosely orange-woolly, glossy dark green, inserted at $40-50^{\circ}$ to rachis, keeled in section with recurved margins, decurrent for $2.5-3.5 \mathrm{~mm}$, narrowed to $2.5-4.0 \mathrm{~mm}$ at base (35-45\% of maximum width), spaced at 10-17 $\mathrm{mm}$ on rachis, apex attenuate; midrib slightly raised above, prominent below. New growth loosely tomentose with orange-brown. trichomes. Cataphylls not pungent, $50-80 \mathrm{~mm}$ long, finely grey-white sericeus. Microsporangiate cones narrow-ovoid, c. $20-30 \mathrm{~cm}$ long, c. $7-11 \mathrm{~cm}$ diam. Microsporophyll lamina 35-45 $\mathrm{mm}$ long, 12-17 mm wide; sterile apex 5-9 $\mathrm{mm}$ long, not recurved, apical spine slender, sharply upturned, 10-16 $\mathrm{mm}$ long. Megasporophylls $10-14 \mathrm{~cm}$ long, grey-tomentose, with $2-6$ ovules, sterile apex $50-65 \mathrm{~mm}$ long, 38-50 $\mathrm{mm}$ 


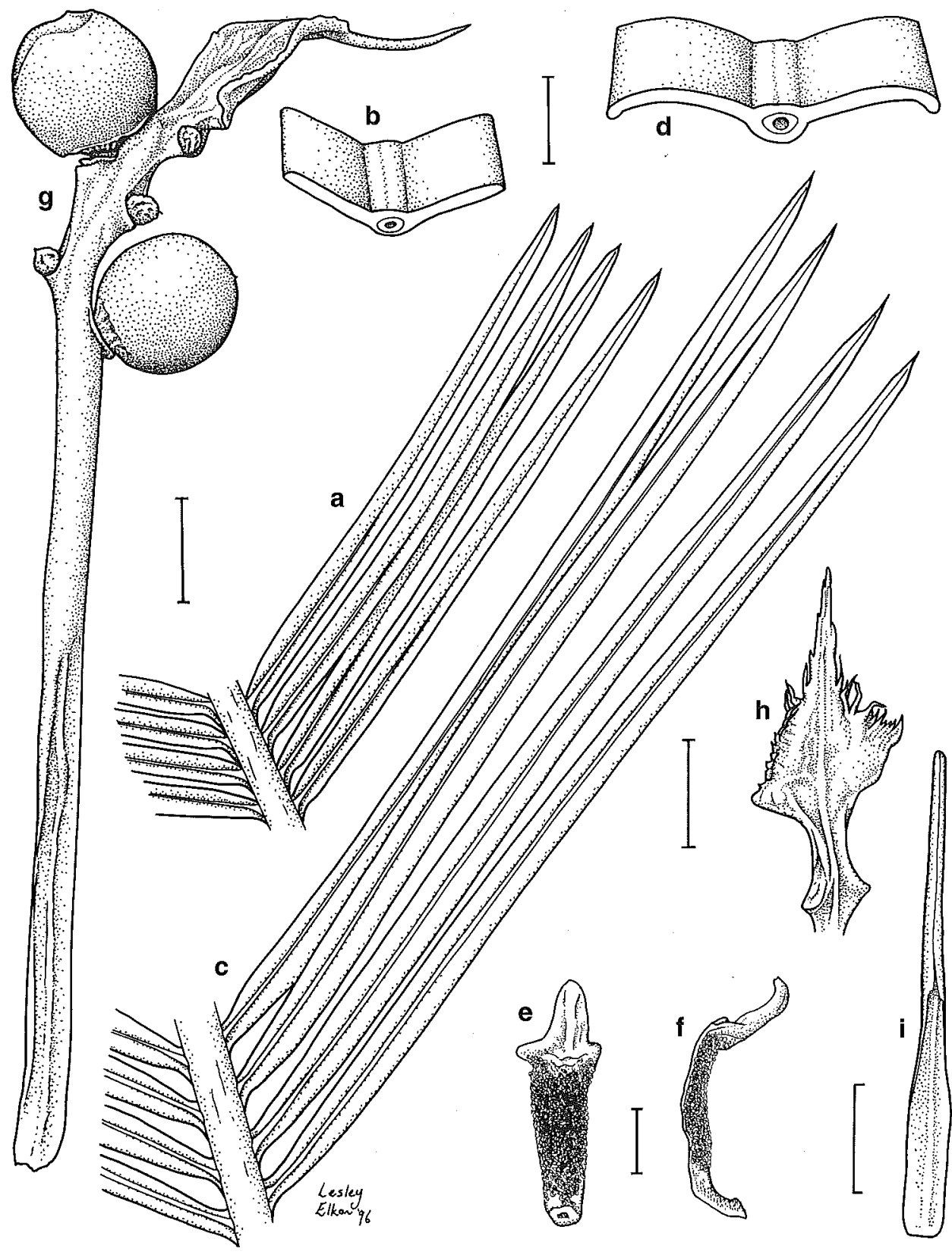

Fig. 9. C. badensis. a, c, part of leaf. $\mathbf{b}, \mathbf{d}$, section of pinna. $\mathbf{e}, \mathbf{f}$, microsporophyll. $\mathbf{g}$, cataphyll. h, megasporophyll with ovules and stipe. $i$, tip of megasporophyll $(a, c, e, f, h, i$ from Harris 130 , b, d, g from Clarkson 4007). Scale bar: a, c, e, f, g, h, i=1 cm; b, d = $2 \mathrm{~mm}$. 


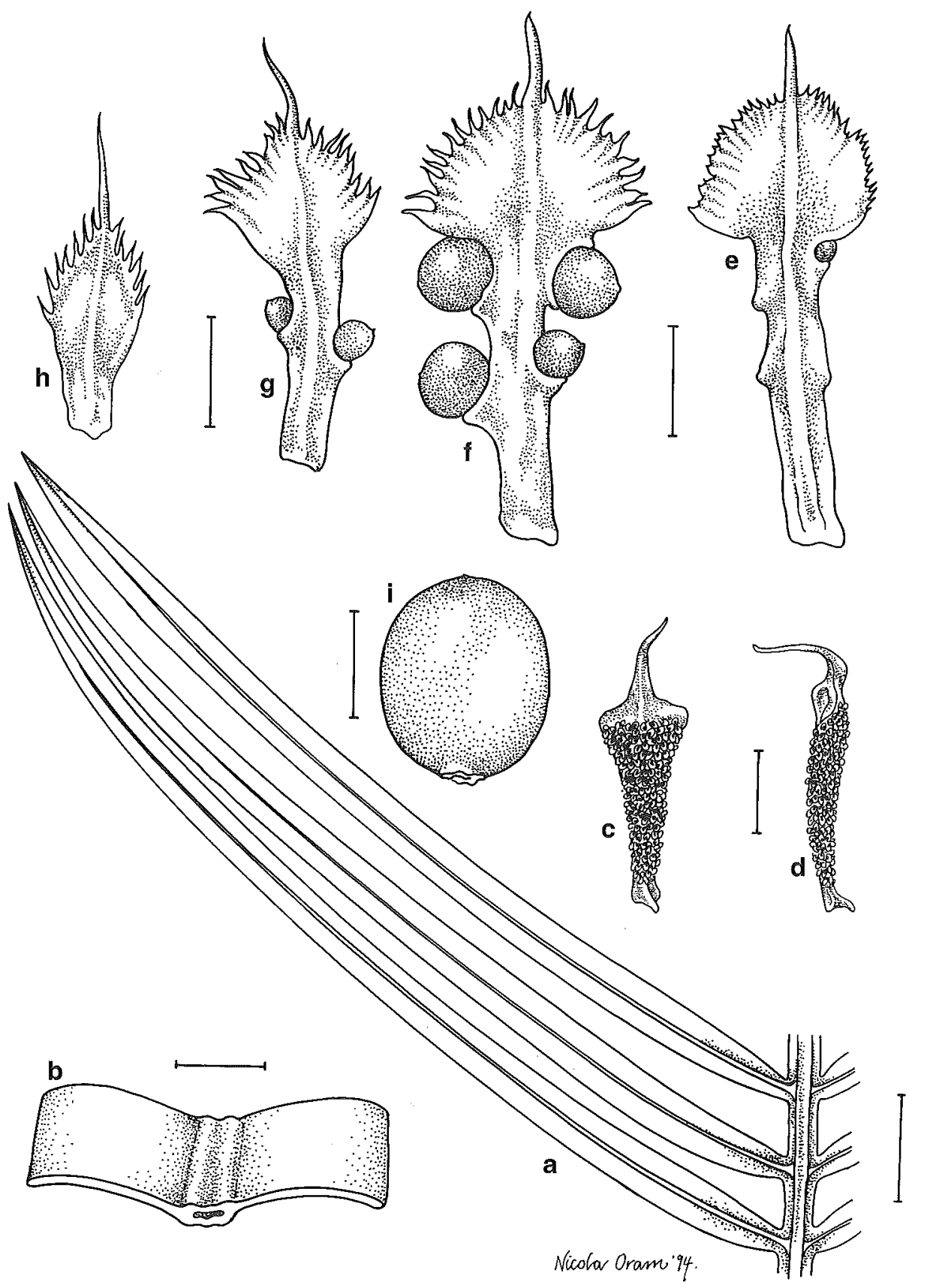

Fig. 10. C. tuckeri. a, part of leaf. $\mathbf{b}$, section of pinna. $\mathbf{c}, \mathbf{d}$, microsporophyll. $\mathbf{e}, \mathbf{f}, \mathbf{g}$, megasporophylls with ovules and stipe, $h$, tip of megasporophyll, $i$, seed $(\mathrm{a}, \mathrm{b}, \mathrm{g}$, h from Hill $4684, \mathrm{c}, \mathrm{d}$ from Hill 4684A, $\mathrm{f}$ from Hill 4685, h from Hill 4683, i from Maconochie 2690). Scale bar: $\mathrm{a}, \mathrm{c}, \mathrm{d}, \mathrm{e}=1 \mathrm{~cm} ; \mathrm{b}=2 \mathrm{~mm}$. 
wide, broadly triangular, regularly dentate, with 22-36 lateral teeth 1-4 mm long, apical spine 19-30 mm long. Seeds flattened-ovoid, green becoming orange, not pruinose, 28-34 mm long, 26-32 mm diam.; sarcotesta 2-3 mm thick. Fig. 10

Leaf anatomy: upper mesophyll interrupted at midrib, composed of palisade and equidimensional cells; lower mesophyll interrupted at midrib, composed of equidimensional and palisade cells; laminar hypodermis continuous, 1 cell layer thick; marginal hypodermis 3 cell layers thick; stomatal crypts shallow, open; subsidiary cells undifferentiated or raised and differentiated; cuticle thick.

Notes: readily distinguished among the Australian species by the very short megasporophylls. Only C. semota from the northern tip of Cape York Peninsula has comparably short megasporophylls, but those of the latter are distinctly longer, and the lamina is longer and narrower. The very short, soft and finely sericeus cataphylls are also distinctive, as is the relatively broad and short megasporophyll lamina.

Distribution: extremely localised and restricted, known at present only from the one population at the type locality (Fig. 7). This species occurs in low open savanna woodland dominated by Eucalyptus cullenii, on gritty soils on stony granite slopes.

Conservation status: further study is required urgently to establish the status of this taxon, but current knowledge would indicate that it is a rare species, potentially at risk. A code of $2 \mathrm{~V}$ - appears appropriate.

Etymology: the epithet honours the late Robert Tucker, former director of the Parks and Gardens Department, Townsville, and a keen naturalist and horticulturist who spotted this plant and recognised its distinctive nature.

Selected specimens: Queensland: Cook: Coen district (precise localities withheld): Hill 4684, 4685 \& Stanberg, 7 Jul 1994 (NSW); Maconochie 2690, 15 Jun 1981 (DNA, BRI, K, NSW).

\section{Cycas semota K.D. Hill, sp. nov.}

Inter subsectionem Endemicae combinatione megasporophylla breviora lamina angusta; cataphylla breviora non pungentia indumento brevissimo, adpresso, distinguitur.

Type: Queensland: Bamaga district, K.D. Hill 4708 \& L. Stanberg, 10 Jul 1994 (holo NSW; iso BRI, CANB, DNA, K, L, MEL, NY).

Stem to $4.0 \mathrm{~m}$ tall, rarely to $6.0 \mathrm{~m}, 14-24 \mathrm{~cm}$ diam. Leaves $110-160 \mathrm{~cm}$ long, openly keeled in section (opposing pinnae inserted at $100-130^{\circ}$ on rachis), with $160-250$ pinnae, terminated by paired pinnae; petiole loosely orange-brown-tomentose, $30-40 \mathrm{~cm}$ long; median pinnae at $55-70^{\circ}$ to rachis, $140-200 \mathrm{~mm}$ long, $6.0-7.5 \mathrm{~mm}$ wide, glabrous or loosely orange-woolly, glossy dark green, keeled in section with recurved margins, decurrent for $2.0-3.0 \mathrm{~mm}$, narrowed to $3.0-4.0 \mathrm{~mm}$ at base $(40-60 \%$ of maximum width), spaced at $8-11 \mathrm{~mm}$ on rachis, apex attenuate; midrib slightly raised above, prominent below. New growth loosely tomentose with orange-brown trichomes. Cataphylls not pungent, $40-70 \mathrm{~mm}$ long, finely grey-white sericeus. Microsporangiate cones not seen. Megasporophylls 10-14 cm long, grey-tomentose, with 2-6 ovules, sterile apex 50-65 mm long, 38-50 mm wide, broadly triangular, regularly dentate, with 22-36 lateral teeth, apical spine 19-30 mm long, lateral teeth 1-4 $\mathrm{mm}$ long. Seeds flattened-ovoid, green becoming orange, not pruinose, $32-37 \mathrm{~mm}$ long, 28-32 mm diam.; sarcotesta 2-3 mm thick. Fig. 11.

Notes: readily distinguished among the Australian species by the short megasporophylls and short, soft cataphylls with short, close indumentum. C. tuckeri from farther south has even shorter megasporophylls, with a distinctly shorter and broader lamina. The type of C. normanbyana has a similarly attenuate megasporophyll 


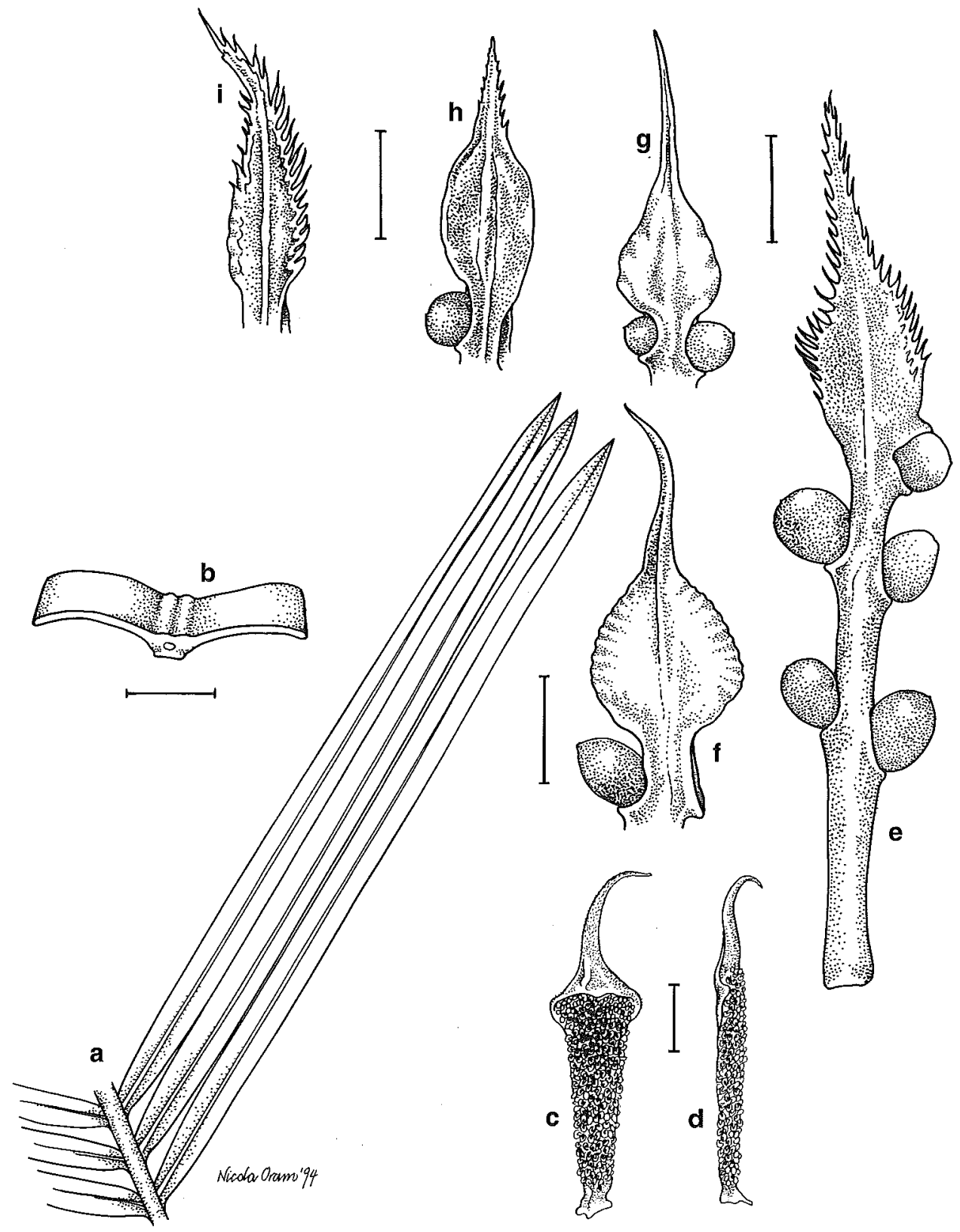

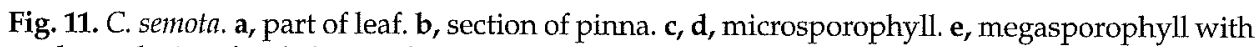
ovules and stipe, $\mathrm{f}, \mathrm{g}, \mathrm{h}$, $\mathrm{i}$, tips of megasporophylls ( $\mathrm{a}, \mathrm{b}, \mathrm{c}, \mathrm{d}$ from Hill 4708 , e from Hill $4708 \mathrm{E}$, $\mathrm{f}$ from Hill 4708B, $\mathrm{g}$ from Hill $4708 \mathrm{D}$, h from Hill $4708 \mathrm{~A}$, i from Hill 4708C). Scale bar: a, c, d, e, f, g, h=2 cm; $\mathrm{i}=1 \mathrm{~cm} ; \mathrm{b}=2 \mathrm{~mm}$. 
lamina, but a much longer overall megasporophyll. Cataphylls and pinnae of the latter also differ (see C. media subsp. media).

Distribution: locally abundant, but apparently restricted to the Bamaga district in far northern Cape York Peninsula (Fig. 7). The known habitat is in grassy understorey of eucalypt forest with Corymbia novoguinensis, C. tessellaris and Erythrophleum chlorostachys. This forest is relatively moist, and often forms a mosaic with mesophyllous forest, on shallow sandy soils over massive laterite.

Conservation status: highly localised and not conserved. All specimens known are from the one population near the town of Bamaga, and under threat for that reason. Further study is required urgently to establish the status of this taxon, but current knowledge would indicate that it is a rare species, potentially at risk. A code of $2 \mathrm{~V}-$ appears appropriate.

Etymology: the epithet is from the Latin semotus, remote or distant, in reference to the occurrence of this taxon in the farthest extremity of Cape York Peninsula.

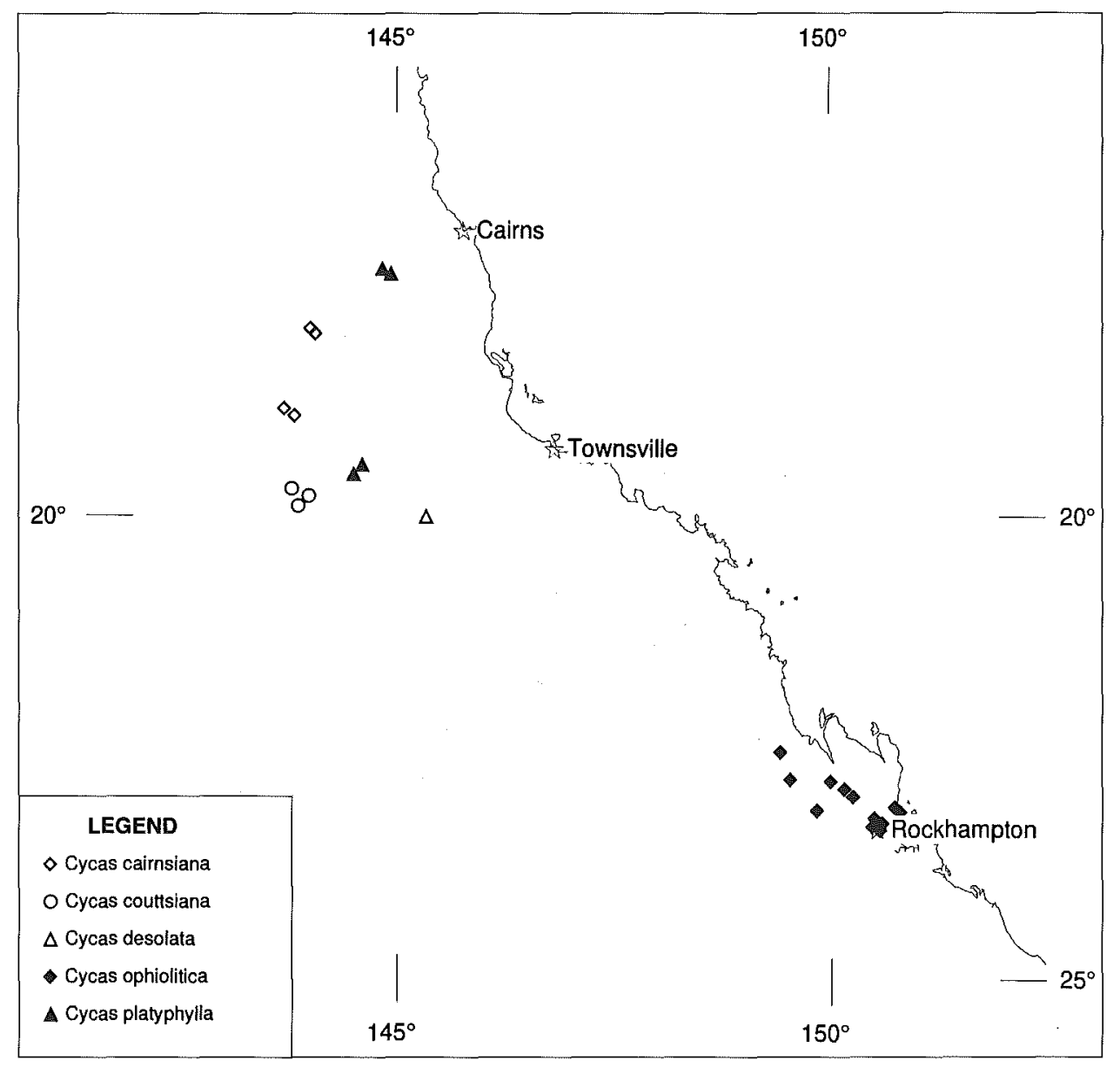

Fig. 12. Distribution of series Caimsianosae. 
Selected specimens: Queensland: Cook: Bamaga district (precise localities withheld): Hill 4706, 4707, 4708A-D \& Stanberg, $10 \mathrm{Jul} 1994$ (NSW); Brass 18924, 22 May 1948 (BRI, K, L; all ex A).

\section{Series Cairnsianosae K.D. Hill, ser. nov.}

Inter series subsectionis Endemicae combinatione folia carinata, pinnis inferioribus non spinescentibus; pinnae glaucissimae recurvae vel revolutae, hypodermide continua; strobili masculi grandes vel aliquantum grandes ovoideis fulves vel ferruginei, distinguitur.

Type species: Cycas cairnsiana F. Muell.

Leaves strongly keeled; basal pinnae not gradually reducing to spines; pinnae recurved to revolute, strongly glaucous; hypodermis fully continuous, often more than one layer of cells; cataphylls soft or hard and pungent; microsporangiate cones medium, ovoid, orange-brown. Upper mesophyll interrupted at midrib, composed of palisade cells only; lower mesophyll continuous. interrupted in C. ophiolitica, composed of partly elongate or palisade cells; laminar hypodermis continuous, stomatal crypts deep, closed; subsidiary cells raised and differentiated; cuticle moderately to very thick.

A series of 5 species, all restricted to central northern Queensland (Fig. 12).

\section{Cycas ophiolitica K.D. Hill, Telopea 5(1): 190 (1992).}

Type: Queensland: Port Curtis District: $48.6 \mathrm{~km} \mathrm{~S}$ of Marlborough on Bruce Highway, K.D. Hill 4140 \& L. Stanberg, 1 Oct 1991 (holo NSW; iso BRI, CANB, K, DNA).

Illustration: Hill (1992: 191, Fig. 7).

See Hill (1992) for description and specimen citations.

Leaf anatomy: upper mesophyll interrupted at midrib, composed of palisade cells only; lower mesophyll interrupted at midrib, composed of equidimensional and palisade cells; laminar hypodermis continuous, 1 cell layer thick; marginal hypodermis 2 cell layers thick; stomatal crypts deep, closed; subsidiary cells undifferentiated; cuticle thick.

Notes: distinguished from other Australian species by the relatively broad, crowded, keeled and more or less glaucous pinnae, the grey- or white-tomentose petioles, the orange-floccose crown, and the small seeds. Pinnae are generally narrower and more crowded than those of both C. media and C. megacarpa, and ovules are fewer in number than those of $C$. media. Leaves are also more frequently (but not always) terminated by a spine rather than a pair of pinnae (both C. media and C. megacarpa show about equal development of terminal spine or pinnae). Pure forms are quite blue in new growth, becoming dark green with age, and have narrow, stiff pinnae. In these characters, C. ophiolitica resembles both C. platyphylla and C. couttsiana. It differs from the former in the somewhat longer and broader pinnae on longer leaves with longer petioles and the lesser amount of orange tomentum around the cataphylls, and from the latter in lacking the persistent white trichomes and by the less keeled leaves.

Although grouped with series Caimsianosae by most characters, this species differs in having wider pinnae with an interrupted lower hypodermis. These are characters present in series Endemicae, members of which show substantial intergradation with C. ophiolitica (see appendix). It is possible that these anomalous characters have arisen through introgressive introduction from the adjacent intergrading species.

The 'core' form of this species is in cultivation (mostly as wild-collected plants) as Cycas 'Marlborough Blue'. Some of the intergrading material is also cultivated as C. normanbyana, although the type of the latter name belongs to C. media (which see). 
Distribution: this species reaches its best development on red clays over serpentinites in the region between Marlborough and Rockhampton (Fig. 12). Substantial intergradation occurs with C. media and C. megacarpa respectively north and south of this region (Fig. 4, and see appendix), and plants from throughout the range may show characters of these taxa.

Conservation status: 2V-. The habitat is poorly conserved (or unconserved), and the species is also under significant commercial collecting pressure.

\section{Cycas platyphylla K.D. Hill, Telopea 5(1): 193 (1992).}

Type: Queensland: Cook District: $4.3 \mathrm{~km}$ from Petford on Herberton road, K.D. Hill 3764 \& L. Stanberg, 1 Aug 1990 (holo NSW; iso BRI, CANB, DNA, MEL).

Illustration: Hill (1992: 194, Fig. 9).

See Hill (1992) for description and specimen citations.

Leaf anatomy: upper mesophyll continuous or interrupted at midrib, composed of palisade and equidimensional cells; lower mesophyll continuous, composed of equidimensional and palisade cells; laminar hypodermis continuous, 1-2 cell layers thick; marginal hypodermis 1-2 cell layers thick; stomatal crypts deep, closed; subsidiary cells raised and differentiated; cuticle very thick.

Notes: distinguished from other Australian species by the initially bluish leaves becoming yellowish green, the moderately broad pinnae with recurved margins, the thick orange tomentum around the cataphylls, and the broad lamina of the megasporophylls.

The name $C$. cairnsiana has been misapplied to this taxon by botanists and growers alike. The type locality of C. caimsiana was unknown for a long period, but has been recently rediscovered.

Distribution: known from the Petford district on the north-western Atherton Tableland, and a disjunct population about $250 \mathrm{~km}$ to the south on Wandovale station (Fig. 12). In both localities, it occurs in open grassy ironbark-dominated woodland on shallow loamy soils on stony slopes over acid to intermediate volcanics.

An extensive and variable population in the Irvinebank - Ravenshoe - Mt Garnet district (Fig. 12) on the western Atherton Tableland is intermediate in all respects between C. platyphylla and C. media. This occurrence is regarded as a highly variable breeding population that was originally of hybrid origin between these two taxa, but would now have limited scope for genetic interchange with the parent species.

Conservation status: $2 \mathrm{~V}$-. The range of this species is small, and none of the habitat is conserved. The species is also under some threat from collectors.

10. Cycas cairnsiana F. Mueller, Fragm. 10: 63 (1876).

Type: Queensland: Newcastle Range, Armit, 1876 (holo MEL 68032).

Illustration: Hill (1992: 196, Fig. 11).

See Hill (1992) for typification, description and specimen citations.

Leaf anatomy: upper mesophyll continuous, composed of palisade and equidimensional cells; lower mesophyll continuous, composed of equidimensional and partly elongate cells; laminar hypodermis continuous, 1-2 cell layers thick; marginal hypodermis 2 cell layers thick; stomatal crypts deep, closed; subsidiary cells raised and differentiated; cuticle very thick. 
Notes: distinguished from other Australian species by the dense but very loose orange tomentum on new growth, the glabrous, strongly waxy and very glaucous mature leaves and seeds, and the very narrow pinnae with strongly recurved margins.

Distribution: known from only two rather extensive and scattered populations about the Newcastle Range in the drier country of north-eastern Queensland, on shallow to skeletal gritty soils over siliceous granites (Fig. 12). Plants from the population near Forsayth have slightly wider pinnae than those from near Mt Surprise.

Conservation status: $2 \mathrm{~V}$-. Although both known populations are large, neither area is conserved and the striking appearance of this plant places it under considerable longterm threat from commercial collectors.

11. Cycas couttsiana K.D. Hill, Telopea 5(1): 197 (1992).

Type: Queensland: Burke District: Chudleigh Park station, Gregory Range, on the upper Stawell River, Hill 3738 \& Stanberg, 29 July 1990 (holo NSW; iso BRI, CANB, DNA, K, MEL).

Illustration: Hill (1992: 198, Fig. 13).

See Hill (1992) for full description and specimen citations.

Leaf anatomy: upper mesophyll continuous, composed of palisade and equidimensional cells; lower mesophyll continuous, composed of equidimensional and partly elongate cells; laminar hypodermis continuous, 1 cell layer thick; marginal hypodermis 2 cell layers thick; stomatal crypts deep, closed; subsidiary cells raised and differentiated; cuticle very thick.

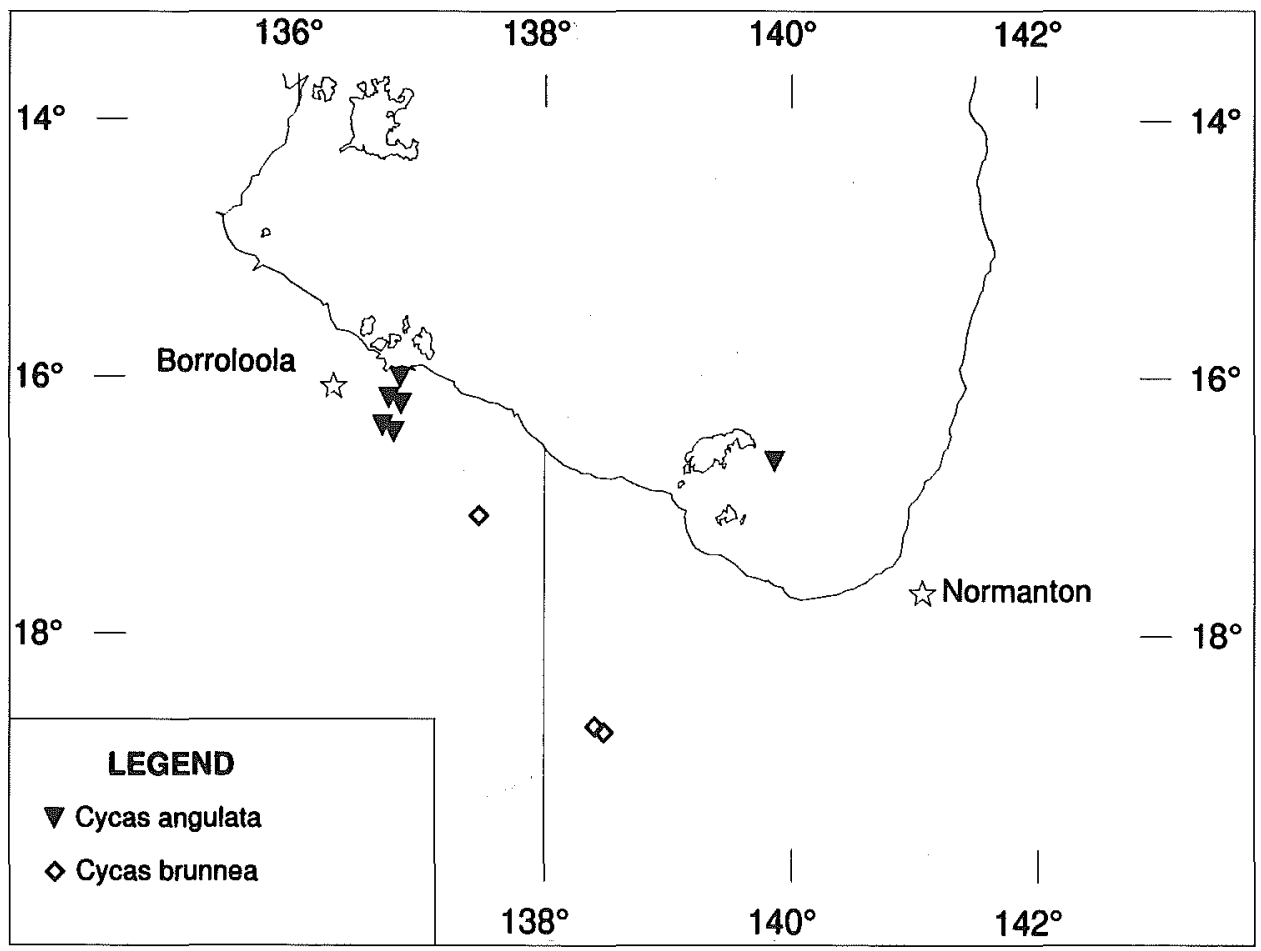

Fig. 13. Distribution of series Angulatosae. 
Notes: distinguished from other Australian species by the relatively broad, subsecund, bluish pinnae with slightly recurved to almost flat margins, the persistent white tomentum, and the strongly glaucous seeds. This species is similar in habit to C. brunnea and $C$. angulata, but the plants are less robust, dark brown trichomes are lacking, and male cones are smaller, ovoid and orange-brown. C. couttsiana also differs from C. angulata in being more glaucous.

Distribution: known from several populations in the southern Gregory Range of Queensland (Fig. 12). It occurs in open grassy woodlands on red sandy loams derived from basalt or dolerite.

Conservation status: 3R- (or 2R-). Although restricted, several of the known populations are large and not under substantial threat.

12. Cycas desolata P.I. Forster, Austrobaileya 4(3): 345 (1995), Figs. 1-5.

Type: Queensland: North Kennedy District: north-west of Charters Towers, P.I. Forster $14671 B$ (male), 27 Jan 1994 (holo BRI).

Illustration: Forster (1995: 345-352, Figs 1-5).

Stems to $4(-7) \mathrm{m}$ tall. Leaves $75-120 \mathrm{~cm}$ long, strongly keeled (opposing pinnae inserted at 30-50 degrees on rachis), with 90-136 pinnae. Petiole 10-23 cm long, unarmed. Median pinnae glabrous, strongly glaucous, light blue, dull, inserted at 40-50 degrees to rachis, $180-210 \mathrm{~mm}$ long, $3.5-5 \mathrm{~mm}$ wide, margins recurved, narrowed to $2.5-4 \mathrm{~mm}$ at base (to $70-80 \%$ of maximum width), $1-5 \mathrm{~mm}$ apart on rachis; midrib flat above, raised below. Cataphylls linear, pungent, 30-45 mm long. Microsporangiate cones narrowly ovoid, orange or brown, $24-40 \mathrm{~cm}$ long, $8-9.5 \mathrm{~cm}$ diam. Microsporophyll lamina 28-38 $\mathrm{mm}$ long, 5-13 $\mathrm{mm}$ wide, apical spine 3-4 $\mathrm{mm}$ long. Megasporophylls 13-24 cm long, with 2-6 ovules; lamina ovate, $28-32 \mathrm{~mm}$ long, 20-25 mm wide, obscurely dentate; apical spine 5-15 mm long. Seeds 35-39 $\mathrm{mm}$ long, 32-35 mm wide.

Notes: distinguished from other Australian species by the strongly glaucous, light blue leaves with relatively few pinnae, and the spine-free petioles.

Distribution: known only from two populations near Charters Towers (Fig. 12).

Conservation status: $2 \mathrm{~V}$-. Known only from small populations on grazing land.

Series Angulatosae K.D. Hill, ser. nov.

Inter series subsectionis Endemicae combinatione folia carinata, pinnis inferioribus non spinescentibus; pinnae plus minusve glaucissimae margine plus minusve revoluta, hypodermide plus minusve continua; cataphylla pungentia; strobili masculi grandes subglobuli fulvi, distinguitur.

Type species: Cycas angulata R. Brown, Prodr: 348 (1810).

Pinnae flat to slightly revolute, slightly to strongly glaucous, margins distinctly recurved; hypodermis extensive, almost or fully continuous; cataphylls hard, pungent; microsporangiate cones large, subglobular, yellow-brown. Upper mesophyll interrupted at midrib, with a distinct basal layer of equidimensional cells; lower mesophyll interrupted at midrib, with well-developed palisade cells; laminar hypodermis continuous, 1 cell layer thick to 2 cell layers thick; stomatal crypts deep, closed; subsidiary cells undifferentiated; cuticle thick.

This group of two species has a sporadic and relictual distribution through an area on the southern side of the Gulf of Carpentaria, in both Queensland and the Northern Territory (Fig. 13). 
13. Cycas brunnea K.D. Hill, Telopea 5(1): 200 (1992).

Type: Queensland: Burke District: Running Waters, Lawn Hill Creek ( $18^{\circ} 43^{\prime} \mathrm{S} 138^{\circ} 28^{\prime} \mathrm{S}$, Maconochie 1661, 16 Nov 1972 (holo DNA; iso BRI).

Illustration: Hill (1992: 201, Fig. 15).

See Hill (1992) for full description and specimen citations.

Leaf anatomy: upper mesophyll interrupted at midrib, composed of palisade and equidimensional cells; lower mesophyll interrupted at midrib, composed of equidimensional and palisade cells; laminar hypodermis continuous, 1-2 cell layers thick; marginal hypodermis 1-2 cell layers thick; stomatal crypts deep, closed; subsidiary cells undifferentiated; cuticle thick.

Notes: distinguished from other Australian species by the relatively broad bluish pinnae with slightly recurved to almost flat margins on openly keeled leaves, the dark brown trichomes on new growth, and the large, strongly glaucous seeds. Most similar to $C$. angulata in habit, the large seeds, the dark brown tomentum, the large, subglobular male cone, and the regularly finely dentate megasporophyll lamina, but distinguished from that species by the broader, flatter pinnae (margins less recurved) which are more widely spaced on the rachis, the generally more strongly glaucous leaves and seeds, and the smaller seeds.

Distribution: known from several populations in the headwaters of Lawn Hill Creek and its tributaries in Queensland, and on Wollogorang station in the Northern Territory (Fig. 13). The Lawn Hill Creek occurrence is on limestone or alluvium derived from limestone, in exposed situations along small, open creek valleys. The Wollogorang occurrences are small relictual stands in sandy alluvium in gorges in siliceous sandstone.

Conservation status: $3 \mathrm{RC}$. Although restricted, several of the known populations are large and not under substantial threat, and are conserved in National Parks.

14. Cycas angulata $R$. Br., Prodr.: 348 (1810).

Type: Queensland: Bountiful Island, R. Brown (holo BM; iso K).

Illustration: Hill (1992: 203, Fig. 17).

See Hill (1992) for typification, description and specimen citations.

Leaf anatomy: upper mesophyll interrupted at midrib, composed of palisade and equidimensional cells; lower mesophyll interrupted at midrib, composed of equidimensional and palisade cells; laminar hypodermis continuous, 1-2 cell layers thick; marginal hypodermis 3 cell layers thick; stomatal crypts deep, closed; subsidiary cells undifferentiated; cuticle very thick.

Notes: distinguished from other Australian species by the very robust habit, the keeled leaves with long, narrow, greyish pinnae arranged at a relatively low angle to the rachis, the large, subglobular male cone, and the long megasporophylls with large numbers of large seeds and a relatively short, finely toothed lamina.

Distribution: a distinctive localised species, known from the lower reaches of the Wearyan, Foelsche and Robinson Rivers near Borroloola, and from the Bountiful Island group further east in the Gulf of Carpentaria (Fig. 13). In both areas it occurs in open grassy woodland or grassland on flat country on sandy alluvium.

This species forms local cycad-dominated woodlands in parts of the Northern Territory, but is less abundant in Queensland, where it is known at present only from offshore islands. 
Conservation status: not considered to be at risk.

Series Armstrongiosae, K.D. Hill, Austral. Syst. Bot. 7: 531 (1994).

Type species: Cycas armstrongii Miquel.

Pinnae flat, green or weakly glaucous, with orange-brown trichomes, margins flat or very slightly recurved; hypodermis absent except for a thin band along leaf margins; cataphylls hard, pungent; cuticle thin; microsporangiate cones small, ovoid, orange to brown. Upper mesophyll interrupted at midrib, composed of palisade cells with few equidimensional cells only; lower mesophyll interrupted at midrib, composed of equidimensional, partly elongated or palisade cells; laminar hypodermis absent; marginal hypodermis reduced; stomatal crypts shallow, open; subsidiary cells undifferentiated; cuticle thin

This series of 7 species occurs in central Cape York Peninsula, Queensland, across the north of the Northern Territory, into the far north of Western Australia. C. papuana from the Western Division of Papua New Guinea also belongs with this group (Fig. 14). All species occur on lateritised deep sandy soil on relatively flat sites, in savanna woodlands or forests.

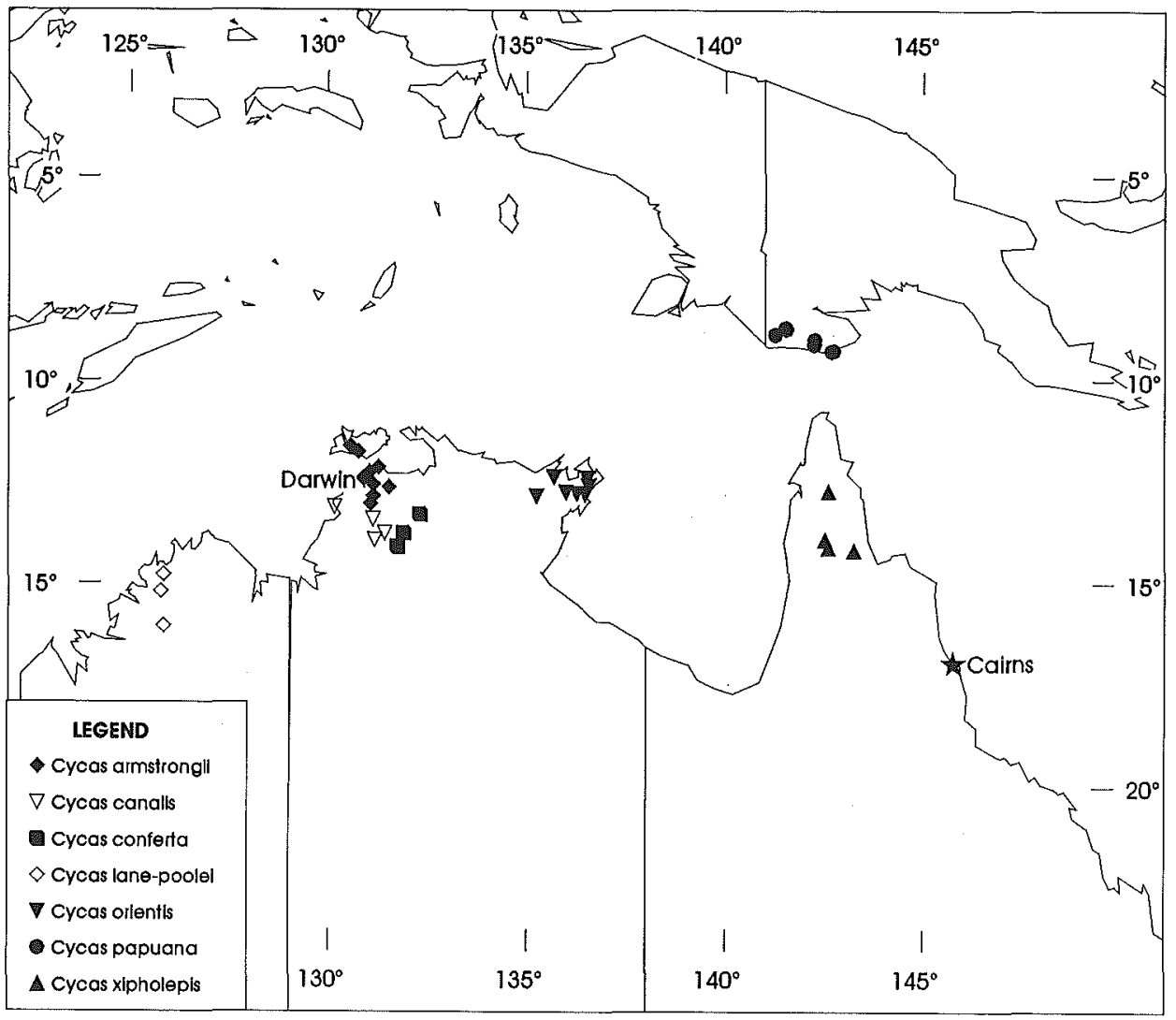

Fig. 14. Distribution of series Armstrongianosae. 


\section{Cycas xipholepis K.D. Hill, sp. nov.}

Inter subsectionem Endemicae combinatione folia atroviridia, petiolis longioribus, pinnis planis et costa utrinque pariter prominula; cataphylla longioria rigida pungentia indumento brevissimo, adpresso, distinguitur.

Type: Queensland: Cook: $10.5 \mathrm{~km}$ W of Telegraph Line road on Batavia Downs to Sudley road, K.D. Hill 4712 E L. Stanberg, 11 Jul 1994 (holo NSW; iso BRI, CANB, DNA, $\mathrm{K}, \mathrm{L}, \mathrm{MEL}, \mathrm{NY}$ ).

Stem to $3 \mathrm{~m}$ tall, rarely to $8 \mathrm{~m}, 10-15 \mathrm{~cm}$ diam. Leaves $70-120 \mathrm{~cm}$ long, flat in section (opposing pinnae inserted at $160-180^{\circ}$ on rachis), with 100-210 pinnae; petiole usually glabrous, 23-35; median pinnae at 70-90 to rachis, $75-150 \mathrm{~mm}$ long, $4.5-7.0 \mathrm{~mm}$ wide, glabrous, glossy dark green, flat in section with flat margins, discolorous, decurrent for $1.5-3.0 \mathrm{~mm}$, narrowed to $3.0-4.0 \mathrm{~mm}$ at base (50-80\% of maximum width), spaced at 6-9 $\mathrm{mm}$ on rachis, apex attenuate; midrib prominent above, prominent below. New growth finely covered with appressed white and orange-brown trichomes. Cataphylls $8-14 \mathrm{~cm}$ long, hard and pungent, indumentum short, appressed, grey. Microsporangiate cones ovoid, c. $20 \mathrm{~cm}$ long, c. $8 \mathrm{~cm}$ diam. Microsporophyll lamina c. $20 \mathrm{~mm}$ long, c. $14 \mathrm{~mm}$ wide; apical spine slender, sharply upturned, geniculate, flat apex c. $6 \mathrm{~mm}$ long, upturned spine c. $10 \mathrm{~mm}$ long. Megasporophylls 15-27 cm long, grey- and orangetomentose, with 2-6 ovules, sterile apex $40-65 \mathrm{~mm}$ long, 20-29 $\mathrm{mm}$ wide, triangular, regularly dentate, with 16-34 lateral teeth, apical spine 17-24 $\mathrm{mm}$ long, lateral teeth 5-7 mm long. Seeds flattened-ovoid, orange, slightly pruinose, 25-36 mm long, 25-34 mm diam.; sarcotesta 3-4 mm thick. Fig. 15.

Notes: distinguished by the dark green leaves with relatively long petioles and flat pinnae with the midrib equally prominent above and below, and the long, hard cataphylls with short, close indumentum.

Distribution: locally abundant on flat sites on deep white to yellow sands over laterites or sometimes on low, stony laterite hills, mainly in savanna forests dominated by Eucalyptus tetrodonta. Widespread in central Cape York Peninsula, from south of Coen to Batavia Downs, west to Merapah (Fig. 14).

Conservation status: locally abundant and very widespread, in remote country, not considered to be at risk.

Etymology: the epithet is from the Greek xiphos, sword, and lepis, scale, referring to the long, hard and pungent cataphylls.

Selected specimens: Queensland: Cook: $30 \mathrm{~km}$ S of Coen, beside main road, Hill 4680 \& Stanberg, 7 Jul 1994 (NSW, BRI, CANB, DNA, K, L, NY, PE); Holroyd station, near homestead, Hill 4720 \& Stanberg, 14 Jul 1994 (NSW).

16. Cycas orientis K.D. Hill, Telopea 5(4): 696 (1994).

Type: Northern Territory: $48.9 \mathrm{~km}$ E of Badalngarrmirri Creek, K.D. Hill $3936 \mathcal{E}$ L. Stanberg, 26 Aug 1991 (holo NSW; iso CANB, DNA).

Illustration: Hill (1994: 697, Fig. 3).

See Hill (1994) for description and specimen citations.

Leaf anatomy: upper mesophyll interrupted at midrib, composed of palisade cells only; lower mesophyll interrupted at midrib, composed of equidimensional and partly elongate cells; laminar hypodermis absent; marginal hypodermis 1 cell layer thick; stomatal crypts shallow, open; subsidiary cells undifferentiated; cuticle very thin. 


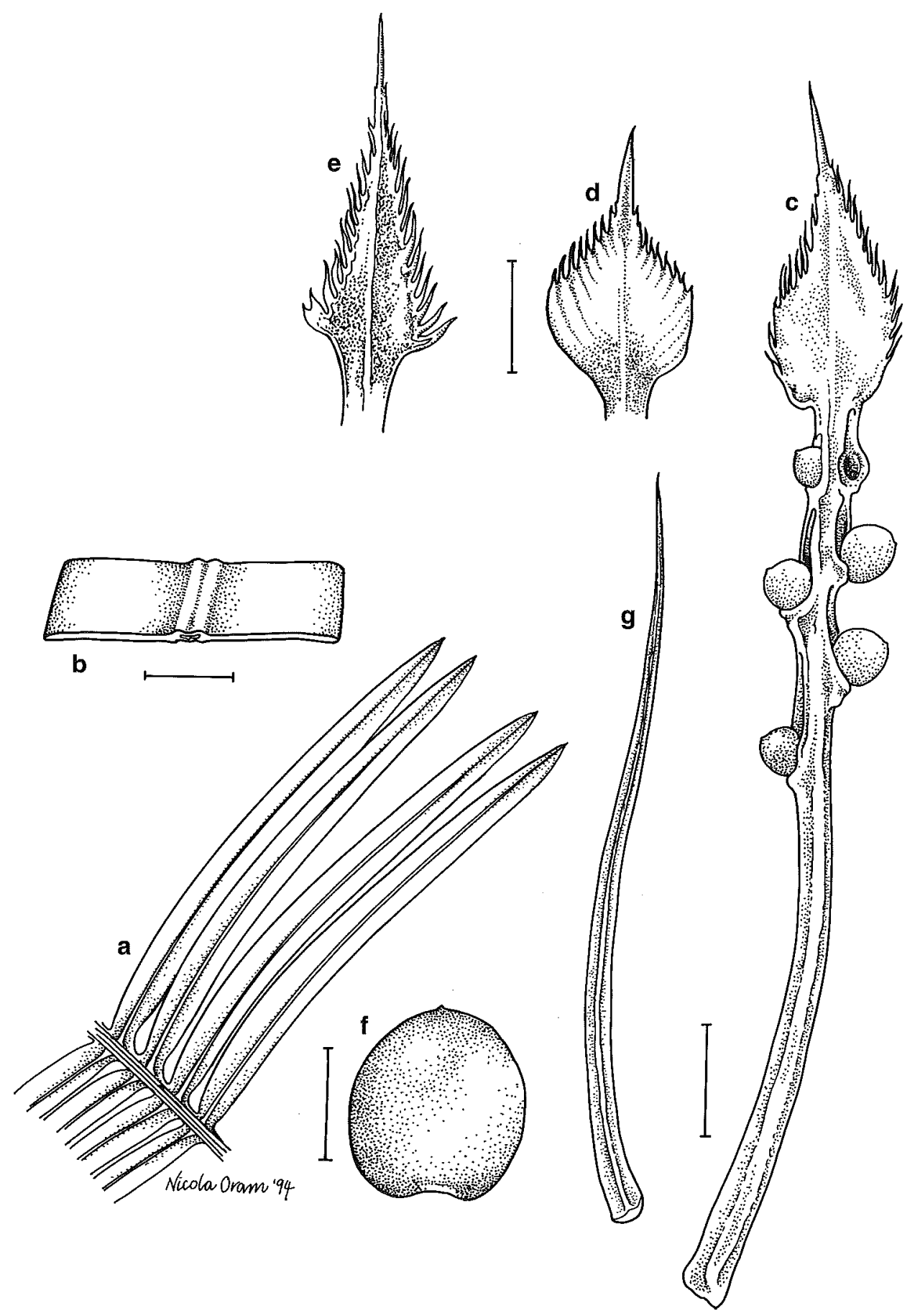

Fig. 15. C. xipholepis. a, part of leaf. $\mathbf{b}$, section of pinna. $\mathbf{c}_{r}$ megasporophyll with ovules and stipe. $\mathrm{d}$, e, tips of megasporophylls. $\mathrm{f}$, seed. $\mathrm{g}$, cataphyll ( $\mathrm{a}, \mathrm{b}, \mathrm{c}, \mathrm{d}, \mathrm{f}, \mathrm{g}$ from Hill 4712, e from Hill 4720). Scale bar: $a, c, d, e, f, g=1 \mathrm{~cm} ; b=2 \mathrm{~mm}$. 
Notes: distinguished by the mid-green leaves with relatively long petioles and flat pinnae with the mid-rib more prominent beneath. Leaves in general resemble those of C. armstrongii, which differs in having the midrib equally prominent on both sides of the pinnae. C. armstrongii also has a generally smaller stature with more slender stems and shorter leaves with shorter petioles.

Distribution: locally abundant on deep white to yellow sands over laterites, mainly in Eucalyptus tetrodonta - E. miniata dominated savanna forests, but occurring in most non-swampy habitats, widespread in eastern Arnhem Land (Fig. 14). Intergradation occurs with $C$. arnhemica where the ranges adjoin.

Conservation status: abundant and widespread, not considered to be at risk. Although not reserved, the extreme abundance of this species would buffer it from any threat in the medium term. Almost all populations are on aboriginal land, and conservation issues on such land are yet to be fully addressed. The inhibition of reproduction by too-frequent fire is one such issue.

17. Cycas conferta Chirgwin in Chirgwin \& Wigston, J. Adelaide Bot. Gard. 15(2): 147 (1993).

Type: Northern Territory, G. Brown s.n., 21 Apr 1987 (holo DNA 29214).

Stem to $4 \mathrm{~m}$ tall, rarely to $7 \mathrm{~m}, 9-13 \mathrm{~cm}$ diam. Leaves $70-110 \mathrm{~cm}$ long, flat or slightly keeled in section (opposing pinnae inserted at $130-180^{\circ}$ on rachis), with $160-240$ pinnae, consistently terminated by a sometimes toothed spine; petiole loosely white-tomentose, usually not spinescent, $20-45 \mathrm{~cm}$ long; median pinnae at $60-90^{\circ}$ to rachis, $70-120 \mathrm{~mm}$ long, $6.0-8.0 \mathrm{~mm}$ wide, glabrous, distinctly blue-green when new, becoming dull to semiglossy mid-green, more or less concolorous, sometimes with stomata on the upper surface near the midrib in the basal half, flat in section, decurrent for 1-2 mm, narrowed to $3.5-5.5 \mathrm{~mm}$ at base (to $60-80 \%$ of maximum width), spaced at $5-8 \mathrm{~mm}$ on rachis, usually closely crowded and overlapping, apex attenuate; midrib about equally prominent above and below. New growth densely tomentose with white and few orange trichomes. Cataphylls densely orange-tomentose, $6-9 \mathrm{~cm}$ long. Microsporangiate cones orange-brown, ovoid, 11-18 cm long, 8-12 cm diam. Microsporophyll lamina 25-29 mm long, 14-17 mm wide; sterile apex 5-9 mm long, not recurved, apical spine slender, sharply upturned, 7-11 mm long. Megasporophylls $17-22 \mathrm{~cm}$ long, grey- and orange-tomentose, with 2-4 ovules, sterile apex $45-75 \mathrm{~mm}$ long, $18-30 \mathrm{~mm}$ wide, narrowly triangular, regularly dentate, with 18-24lateral teeth, apical spine c. $8 \mathrm{~mm}$ long, lateral teeth 1-3 mm long, $1 \mathrm{~mm}$ wide. Seeds narrow-ovoid, green becoming orange, pruinose, c. $40 \mathrm{~mm}$ long, c. $30 \mathrm{~mm}$ diam.; sarcotesta 3-4 mm thick. Fig. 16.

Leaf anatomy: upper mesophyll interrupted at midrib, composed of palisade and equidimensional cells; lower mesophyll interrupted at midrib, composed of equidimensional and partly elongate cells; laminar hypodermis absent; marginal hypodermis 1-2 cell layers thick; stomatal crypts shallow, open; subsidiary cells undifferentiated; cuticle very thin.

Notes: distinguished by the dull, pale green and usually very slightly bluish leaves with relatively long and usually unarmed petioles and broad, closely crowded, concolorous and often partly amphistomatic pinnae. C. armstrongii has been confused with this species, but differs in the shorter, more frequently spinescent petioles and the glossy, discolorous and more widely spaced pinnae. The habit of $C$. armstrongii is also smaller. C. papuana from the Western District of Papua New Guinea shares the long petioles and crowded, concolorous pinnae, but has more robust male cones with elongated, decurved sterile apices on the male sporophylls. 
Distribution: a somewhat restricted species, usually occurring on sandy soils over granites or coarse sandstones. Sporadic and local in occurrence, forming isolated, usually small but dense, stands from Kakadu National Park (near Twin Falls and Goodparla homestead) to west of Pine Creek (Fig. 14). Populations at Mt Bundey and near Hayes Creek are intermediate between $C$. conferta and C. armstrongii, and those at Goodparla show slight $C$. armstrongii influence. Apparent hybrids with C. calcicola are also known.

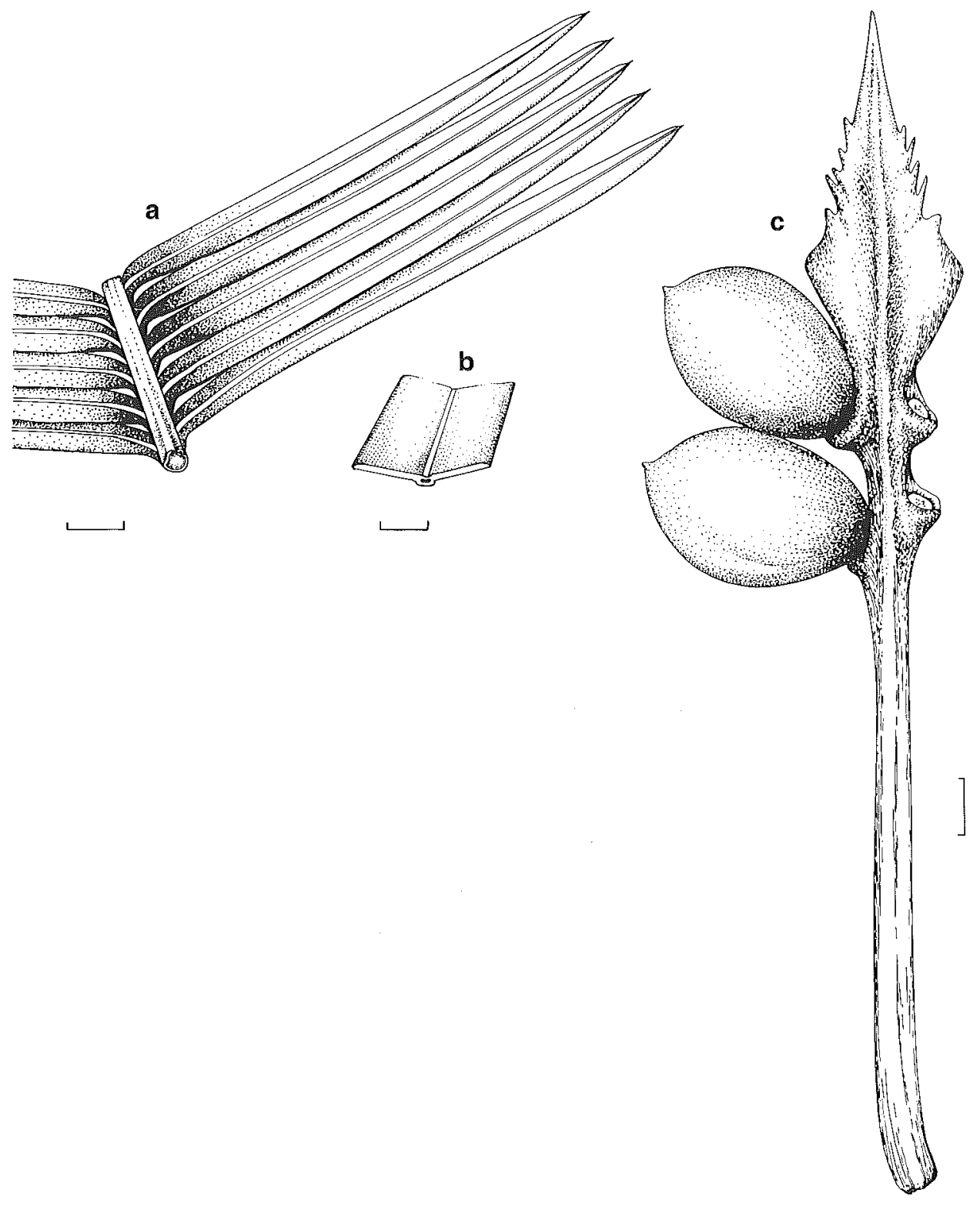

Fig. 16. C. conferta. a, part of leaf. $\mathbf{b}$, section of pinna. $\mathbf{c}$, megasporophyll with seed and stipe (from Hill 4059). Scale bar: a, c $=1 \mathrm{~cm} ; \mathrm{b}=2 \mathrm{~mm}$. 
Conservation status: 2VC-. Populations are small and localised, and under some threat from collectors. Regeneration is also threatened by frequent fires and, to a lesser extent, seed collectors, even though some stands are conserved within Kakadu National Park.

Selected specimens: Northern Territory: Darwin \& Gulf: Pine Creek to Cooinda road, Chirgwin, 9 Oct 1987 (NSW); Harriet Creek, Chirgwin, 15 May 1988 (NSW); near Foelsche Headland, (DNA); $104.2 \mathrm{~km}$ from Arnhem Highway on Kakadu Highway (2.5 km SW of South Alligator crossing), Hill 4014 \& Stanberg, 2 Sep 1991 (NSW, CANB); $4.6 \mathrm{~km}$ from Kakadu Highway on old Goodparla track, Hill 4022 \& Stanberg, 3 Sep 1991 (NSW, CANB); Harriet Creek, 25.0 km from Pine Creek, Hill 4059 \& Stanberg, 10 Sep 1991 (NSW, CANB); 19 miles [30 km] NE of Pine Creek, Morrison, 6 Jun 1972 (DNA).

18. Cycas armstrongii Miquel, Arch. Neerl. Sci. Exact. Nat. 3(5): 235 (1868).

[Cycas media R. Brown forma inermis Miquel, Arch. Neerl. Sci. Exact. Nat. 3(5): 235 (1868), in syn.]

Cycas media R.Brown var. inermis A. de Candolle, Prodr. 16(2): 528 (1868).

Type: Northern Territory: Port Essington, Armstrong 380 (holo K, U (photo seen)). See discussion below.

Stem to $3 \mathrm{~m}$ tall, rarely to $6 \mathrm{~m}, 5-11 \mathrm{~cm}$ diam. Leaves $55-90 \mathrm{~cm}$ long, usually somewhat keeled in section (opposing pinnae inserted at $130-160$, sometimes to $180^{\circ}$ on rachis), with 100-220 pinnae, frequently terminated by a spine; petiole usually glabrous, usually with spines for part of length, $10-25$, sometimes to $35 \mathrm{~cm}$ long; median pinnae at $70-90^{\circ}$ to rachis, $55-140 \mathrm{~mm}$ long, $4.5-8.0 \mathrm{~mm}$ wide, glabrous, dull green or slightly bluish-green when developing, becoming glossy mid-green at maturity, flat in section. with flat margins, discolorous, decurrent for $3.0-5.0 \mathrm{~mm}$, narrowed to $3.5-5.0 \mathrm{~mm}$ at base (to $50-85 \%$ of maximum width), $6.0-14.0 \mathrm{~mm}$ apart on rachis, apex attenuate; midrib more or less equally prominent above and below. New growth densely loosely tomentose with white and few orange trichomes, quickly becoming glabrous. Cataphylls densely orange-tomentose. Microsporangiate cones orange, ovoid, $11-20 \mathrm{~cm}$ long, $7.5-10 \mathrm{~cm}$ diam. Microsporophyll lamina $24-28 \mathrm{~mm}$ long, $14-17 \mathrm{~mm}$ wide; sterile apex 4-6 mm long, not recurved, apical spine slender, sharply upturned, 7-10 $\mathrm{mm}$ long. Megasporophylls $13-22 \mathrm{~cm}$ long, grey- and orange-tomentose, with 2-4 ovules, sterile apex $30-70 \mathrm{~mm}$ long, $18-35 \mathrm{~mm}$ wide, triangular, regularly dentate, with 20-28 lateral teeth, apical spine $10-25 \mathrm{~mm}$ long, lateral teeth $1-4 \mathrm{~mm}$ long, 1-2 mm wide. Seeds flattened-ovoid, green becoming orange, not pruinose, $34-37 \mathrm{~mm}$ long, 32-36 mm diam.; sarcotesta 3-4 mm thick. Fig. 17.

Leaf anatomy: upper mesophyll interrupted at midrib, composed of palisade cells only; lower mesophyll interrupted at midrib, composed of equidimensional and partly elongate cells; laminar hypodermis absent; marginal hypodermis 2 cell layers thick; stomatal crypts shallow, open; subsidiary cells undifferentiated; cuticle very thin.

Notes: distinguished by the glossy green mature new growth and the discolorous pinnae with the midrib equally prominent above and below. This species also has the smallest overall stature of all Australian taxa. Originally distinguished on the basis of the thornless petiole, but petioles are frequently at least partly spinose, and wholly unarmed only on about $10-15 \%$ of individuals in a population. This contrasts with C. conferta, which has unarmed petioles in about $90 \%$ of individuals in a population. The holotype specimen does not have a complete petiole, but Armstrong 379 does. The petiole of the latter is unarmed, and about $35 \mathrm{~cm}$ long, which is outside the usual range for $C$. armstrongii. The pinnae, however, are well-spaced and match C. armstrongii rather than $C$. conferta (the spacing is $10-12 \mathrm{~mm}$, whereas that of C. conferta is usually less than $8 \mathrm{~mm}$ ). 


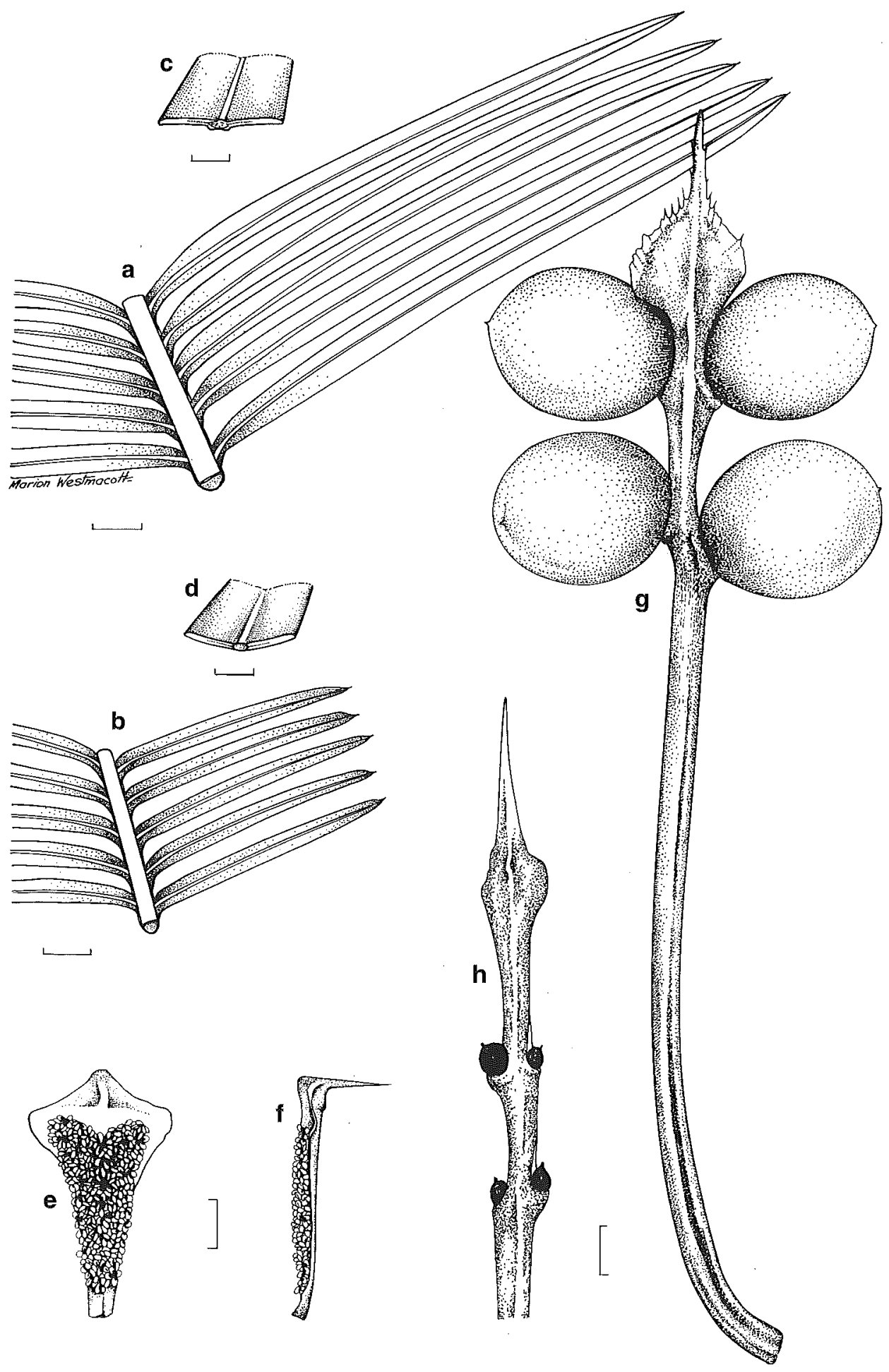

Fig. 17. C. armstrongii. $\mathbf{a}, \mathbf{b}$ parts of leaves. $\mathbf{c}, \mathbf{d}$, sections of pinnae. $\mathbf{e}, \mathbf{f}$, microsporophyll. $\mathrm{g}$, megasporophyll with seed and stipe. $\mathrm{h}$, tip of megasporophyll $(\mathrm{a}, \mathrm{c}, \mathrm{e}, \mathrm{f}$ from Parker NSW137882, $\mathrm{b}, \mathrm{d}, \mathrm{g}$ from Blaxell 88/087, $\mathrm{h}$ from Stone 10658). Scale bar: $\mathrm{a}, \mathrm{b}, \mathrm{g}, \mathrm{h}=1 \mathrm{~cm} ; \mathrm{c}, \mathrm{d}=2 \mathrm{~mm} ; \mathrm{e}, \mathrm{f}=5 \mathrm{~mm}$. 
This species is facultatively deciduous late in the dry season of the monsoonal climatic cycle experienced in its natural habitat. Plants in cultivation or in locally wetter sites can retain leaves for longer, but become dormant, and it appears that the strong seasonal stress is required to rejuvenate plants. Regular (almost annual) dry-season fires experienced over much of the range also promote leaf-drop, and fertile plants are frequently seen with reproductive structure only, and no leaves. The regular fires can also kill the above-ground parts of shorter plants, promoting below-ground branching from an often massive swollen subterranean caudex.

Distribution: an abundant species, in dense and extensive populations on sand over Tertiary laterites in Eucalyptus miniata - E. tetrodonta forests around Darwin. It extends from the Adelaide River west to the Finniss River and south to the township of Adelaide River, with sporadic occurrences farther south almost to Hayes Creek and in a limited area on Melville Island (Fig. 14). Intergrading populations with C. conferta occur at Mt Bundey and near Hayes Creek, and apparent hybrids are known with C. maconochiei subsp. maconochiei.

Typification: the type was cited as 'In Nova Hollandia boreali ad portum Essington legit Armstrong n. 380 herb. Hookeri.' John Armstrong was a collector for Kew Gardens appointed to establish a government garden at Port Essington in 1838. He then collected in Timor in 1839-45. His collecting ranged beyond the immediate environment of the Port Essington settlement, a number of the plants he collected not being known from that site (including Cycas spp.). C. armstrongii has a limited natural distribution, occurring only in the Darwin district, and the type must have originated from there, considerably to the west of the Port Essington settlement site. Three sheets are present in K, one labelled 'No. 379/Coll. in April 1839 at Port Essington', another labelled 'Port Essington/Australia/Armstrong', and the third labelled 'Port Essington/ (bis)'. The U specimen consists of two pinnae only, but with the rachis cut to match the second of the above $\mathrm{K}$ sheets. It appears that the second and third $\mathrm{K}$ sheets and the $\mathrm{U}$ sheet are all parts of Armstrong 380, and consequently parts of the holotype. Bentham (1873) included $C$. armstrongii in C. media, and his treatment was followed until Maconochie (1980) recognised the distinctive nature of $C$. atmstrongii, although not on the basis of the unarmed petiole as Miquel had done originally (see below). Although Miquel in the protologue referred to previous publications of forma inemis (Miquel 1842: 7,$17 ; 1847: 412$ ), this combination was not actually published in these papers, he merely discussed the unusual thornless specimen. This is also an indication that Miquel had seen more than just the U specimen, which has no petiole.

Conservation status: locally extremely abundant, not considered to be at risk. Although not well reserved, the extreme abundance of this species would buffer it from any threat in the medium term. However, frequent fire effectively blocks reproduction, and uncontrolled development progressively alienates significant proportions of the habitat. Several of the Northern Territory species, including this one, are probably the most abundant of all cycads, with populations numbering into tens of millions.

Selected specimens: Northern Territory: Darwin \& Gulf: $19 \mathrm{~km}$ E of Stuart Highway on Arnhem Highway, Blaxell 88/087 \& Wrigley, 23 July 1988 (NSW); Noonamah, Bymes 2456, 13 Jan 1972 (DNA, BRI); Humpty Doo road, Bymes 2464, 18 Jan 1972 (DNA, AD); Melville Island, near Pularumpi police station, Chirgwin, 8 Apr 1988 (NSW); Batchelor demonstration farm, Hill 14, Sep 1913 (NSW); Mt Saunders swamp area, Hinz A42 - 73, 3 Feb 1973 (DNA, K); 11 miles [18 km] SE of Darwin, Jacobs 1746, 29 May 1974 (NSW, DNA); track opposite entrance to General Prawn Co.r Channel Island Rd, c. $10 \mathrm{~km}$ from Palmerston, Johnstone 24, Jul 1987 (NSW); 2 miles [3.2 km] E of Rum Jungle, Maconochie 338, 5 Jun 1967 (DNA); 0.5 mile [0.8 km] E of Casuarina Beach, Darwin, Maconochie 537, 12 Feb 1968 (DNA); Stuart Hwy, 40 miles [64 km] S of Darwin, Maconochie 1308, 10 Jun 1971 (DNA, BRI); 16 km WSW of Wild Boar abattoirs, Maconochie 1620, 1 Jul 1972 (DNA, CANB, K); 57.5 miles [95 km] S of Darwin, Must 735 - 748, 30 Jul 1971 (DNA); Darwin area, Parker s.n., Sep 1976 (NSW137882); vicinity of Darwin, Stone 10658, 4 Sep 1971 (NSW ex Univ. Malaysia). 
C. armstrongii - C. conferta (10 specimens)

Northern Territory: $15 \mathrm{~km}$ from old highway on Daly River road, Hill $4058 \mathcal{E}$ Stanberg, 10 Sep 1991 (NSW, CANB); 3.2 km W of Mary River crossing, Maconochie 1618, 29 Jun 1972 (DNA, MO).

19. Cycas canalis K.D. Hill, Telopea 5(4): 698 (1994).

Type: Northern Territory: $31.4 \mathrm{~km}$ from Labelle Downs homestead on track to Channel Point, K.D. Hill 4034 \& L. Stanberg, 8 Sep 1991 (holo NSW; iso CANB, DNA)

See Hill (1994) for description and specimen citations.

Leaf anatomy: upper mesophyll interrupted at midrib, composed of palisade and equidimensional cells; lower mesophyll interrupted at midrib, composed of equidimensional and partly elongate to palisade cells; laminar hypodermis absent; marginal hypodermis 2 cell layers thick; stomatal crypts shallow, open; subsidiary cells undifferentiated; cuticle very thin.

Notes: distinguished by the strongly glaucous new growth, the long pinnae with flat margins and midrib more prominent below, and the thickly woolly and prominent cataphylls.

Distribution: widespread and locally abundant, on a variety of well-drained soil types, usually on lateritic soil profiles in open forest or woodland with Eucalyptus miniata. Known from near-coastal sites at Channel Point, apparently disjunct from inland occurrences extending from west of Dorisvale to around Douglas Daly reserve (Fig. 14). The inland populations differ in the longer leaves, petioles and pinnae, and the keeled leaves, and the lower rachis-to-pinna angle, and have been recognised as a distinct subspecies.

\section{Key to the subspecies}

1 Pinna-to-rachis angle $50^{\circ}$ or more, leaves flat 19A. subsp. canalis

$1^{*}$ Pinna-to-rachis angle less than $50^{\circ}$, leaves openly keeled 19B. subsp. carinata

\section{A. Cycas canalis subsp. canalis}

Illustration: Hill (1994: 699, Fig. 4a-d).

See Hill (1994) for description and specimen citations.

Distinguished from the following subspecies by the non-keeled leaves and the high pinna-to-rachis angle (50-90 ). Leaves also tend to be somewhat smaller $(60-90 \mathrm{~cm}$ long) with smaller pinnae $(100-190 \times 4.5-7.5 \mathrm{~mm})$.

Locally abundant in near-coastal situations, on well-drained soil in Eucalyptus miniata forest. Known from around Channel Point, to the north of the mouth of the Daly River (Fig. 14), and reported from coastal country south of the mouth of the Daly River (no confirmatory specimens are known).

Conservation status: locally extremely abundant, not considered to be at risk. Although not well reserved, the extreme abundance of this species would buffer it from any threat in the medium term. However, frequent fire effectively blocks reproduction, and uncontrolled development could potentially destroy large proportions of the population. 
19B. Cycas canalis subsp. carinata K.D. Hill (1994: 700)

Type: Northern Territory: $90.0 \mathrm{~km}$ from Stuart Highway on Dorisvale road, K.D. Hill 4063 E L.M. Stanberg, 11 Sep 1991 (NSW).

Illustration: Hill (1994: 699, Fig. 4e-g).

See Hill (1994) for description and specimen citations.

Distinguished from subsp. canalis by the keeled leaves and the low pinna-to-rachis angle $\left(40-50^{\circ}\right)$. Leaves also tend to be longer $(70-105 \mathrm{~cm}$ long), with larger pinnae $(125-205 \times 4.5-8 \mathrm{~mm})$.

A sporadic and scattered taxon, usually on lateritic soil profiles in open forest or woodland with Eucalyptus miniata. Known from west of Dorisvale to around Douglas Daly Reserve (Fig. 14).

Conservation status: Widespread, not considered to be at risk.

20. Cycas lane-poolei C.A. Gardner, Bull. Woods Forests Dept., Western Australia 32: 30, Fig. E (1923).

Cycas media R.Brown var. lane-poolei (C.A. Gardner) Schuster, Pflanzenr. 99: 78 (1932).

Type: Western Australia: near Mount Hann, Kimberley, C.A. Gardner 1444, 29 June 1921 (holo PERTH). Cited as 'The type is No. 1444 of the Forests Department Herbarium.'

Illustration: Gardner (1923: 30, Fig. E).

Stem to $4-5 \mathrm{~m}$ tall, rarely to $8 \mathrm{~m}, 12-15 \mathrm{~cm}$ diam. Leaves $60-110 \mathrm{~cm}$ long, usually somewhat keeled in section (opposing pinnae inserted at 130-180 degrees on rachis), with 90-170 pinnae, usually terminated by a spine; petiole usually glabrous, usually not spinescent or with few distal spines, $18-40 \mathrm{~cm}$ long; median pinnae at $45-60^{\circ}$ to rachis, $60-170 \mathrm{~mm}$ long, $4.5-8.5 \mathrm{~mm}$ wide, glabrous, dull green or slightly bluish-green to strongly glaucous when new, becoming glossy mid-green, flat in section with flat margins, discolorous, decurrent for 3-5 mm, narrowed to $2.5-4 \mathrm{~mm}$ at base $(40-70 \%$ of maximum width), usually well-spaced on rachis (spaced at 4-12 $\mathrm{mm}$ ), apex attenuate; midrib more or less equally prominent above and below. New growth densely loosely tomentose with white and few orange trichomes, quickly becoming glabrous. Cataphylls pungent, densely orange-tomentose, 6-10 cm long. Microsporangiate cones pale orange-brown, ovoid, $10-18 \mathrm{~cm}$ long, 9-11 cm diam. Microsporophyll lamina 22-26 mm long, 14-16 $\mathrm{mm}$ wide; sterile apex 5-10 $\mathrm{mm}$ long, not recurved, apical spine slender, sharply upturned, 8-11 mm long. Megasporophylls $16-22 \mathrm{~cm}$ long, grey and pale brown-tomentose, with $2-4$ ovules, sterile apex $40-65 \mathrm{~mm}$ long, $17-28 \mathrm{~mm}$ wide, narrowly triangular, regularly dentate, with 12-30 lateral teeth, apical spine 15-20 mm long, lateral teeth 1-5 mm long, 1-2 mm wide. Seeds flattened-ovoid, green becoming orange, not pruinose, $38-45 \mathrm{~mm}$ long, $36-40 \mathrm{~mm}$ diam.; sarcotesta 3-4 mm thick. Fig. 18.

Leaf anatomy: upper mesophyll interrupted at midrib, composed of palisade and equidimensional cells; lower mesophyll interrupted at midrib, composed of equidimensional and partly elongate to palisade cells; laminar hypodermis absent; marginal hypodermis 1 cell layer thick; stomatal crypts shallow, open; subsidiary cells undifferentiated; cuticle very thin.

Notes: distinguished by the glossy green to slightly blueish new growth and the discolorous pinnae with midrib equally prominent above and below. The leaves are very similar to those of $C$. armstrongii, but the plant is more robust in all respects. Cataphylls are coated with a thick wool similar to that present in $C$. canalis and C. lanata, but not seen in C. armstrongii. 
Distribution: known from several scattered populations in the north-west of the Kimberley region of Western Australia, mostly on sandy soils in savanna forest with Eucalyptus miniata, E. tetrodonta or Corymbia latifolia (Fig. 14). Intergradational populations with C. basaltica are known.

Conservation status: not considered to be at risk.

Selected specimens: Western Australia: Gardner: south end of Mitchell Plateau, Beard 7037, 12 Jun 1974 (PERTH, DNA); Mitchell River station, Edey, Aug 1971 (DNA); 16 km from Mitchell Falls track on old Mitchell River homestead track, Hill 4077 \& Stanberg, 15 Sep 1991 (NSW, CANB); cult. Mt Elizabeth homestead, plant from near Mt Jameson, upper Drysdale River, Hill 4103

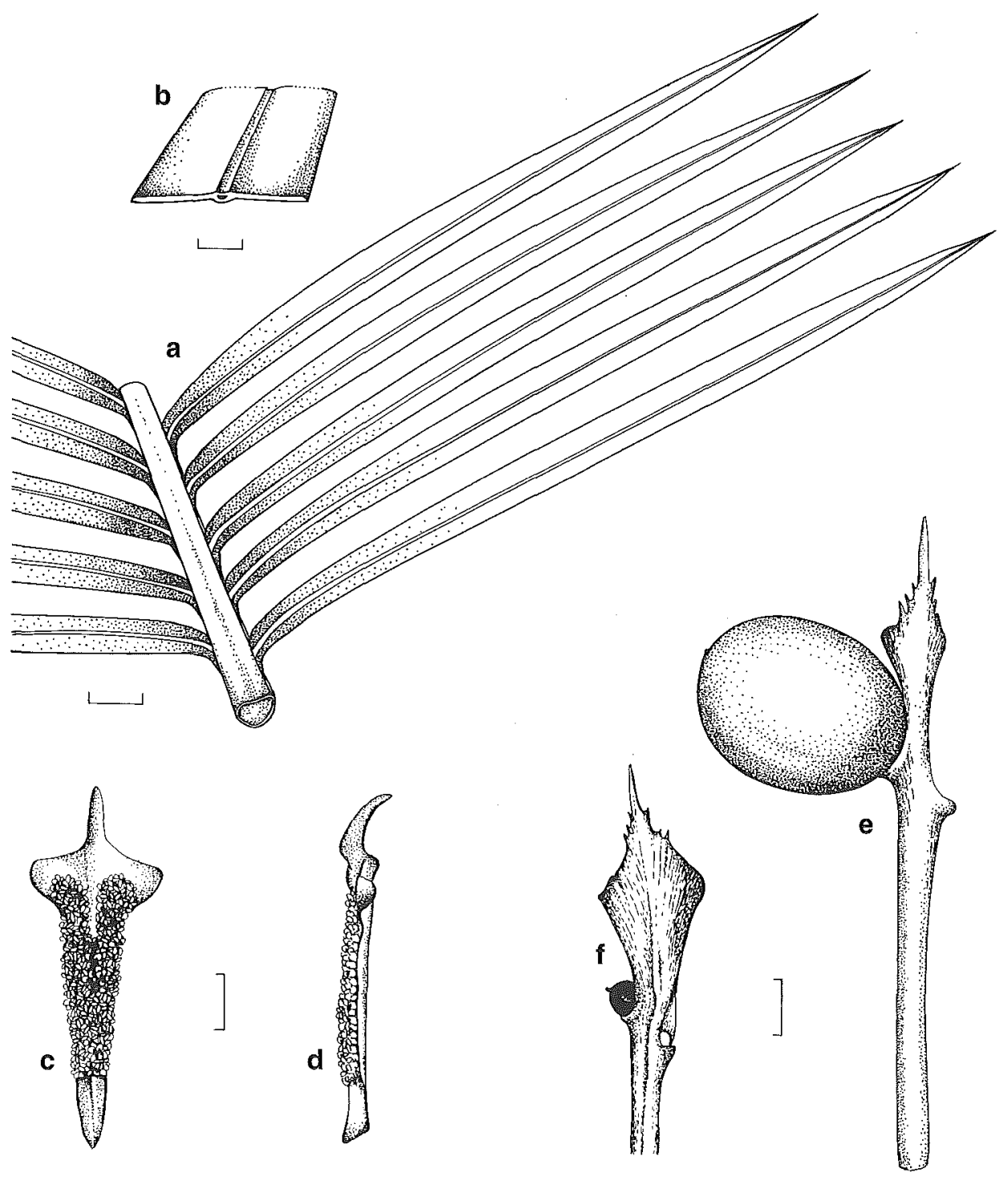

Fig. 18. C. lane-poolei. $a$, part of leaf. $b$, section of pinna. $c, d$, microsporophyll. $e$, megasporophyll with seed and stipe. $f$, tip of megasporophyll (a, b, e from Hill 4077, c, d from Maconochie 1283, $f$ from Lullfitz 57). Scale bar: $a, e, f=1 \mathrm{~cm} ; b=2 \mathrm{~mm} ; c, d=5 \mathrm{~mm}$. 
\& Stanberg, 18 Sep 1991 (NSW); Mitchell Plateau, Lullfitz 57, 19 July 1970 (NSW ex PERTH); c. 18 miles [30 km] S of Amax bauxite camp, Mitchell Plateau, Maconochie 1283, 2 Jun 1971 (DNA, K, L); Mt Agnes, NW Kimberley, J.A. Smith, Aug 1980 (PERTH, DNA).

Series Calcicolosae K.D. Hill, series nov.

Inter series subsectionis Endemicae combinatione folia plana, pinnis inferioribus gradatim decrescentibus non spinescentibus, margine plus minusve revoluto, hypodermide plus minusve continua; cataphylla non pungentia; strobili masculi aliquantum parvi ovoidei vel fusiformes, fuscovirides vel ferruginei, distinguitur.

Type species: Cycas calcicola Maconochie.

Basal pinnae gradually reducing is size but not always merging into spines; leaves more or less flat (opposing pinnae inserted at about $180^{\circ}$ ); pinnae green or weakly glaucous, with white and orange-brown trichomes, margins more or less recurved, midrib prominent below; hypodermis extensive, almost or fully continuous; cataphylls soft, not pungent; microsporangiate cones small, ovoid, orange-brown. Upper mesophyll interrupted or continuous across midrib, composed of palisade cells with few equidimensional cells only; lower mesophyll interrupted at midrib, with well-developed palisade cells; laminar hypodermis continuous, often more than 1 cell layer thick; stomatal crypts variable from shallow and open to deep and closed; subsidiary cells slightly raised and differentiated; cuticle moderately thick.

This group of four species is restricted to the north of the Northern Territory (Fig. 19).

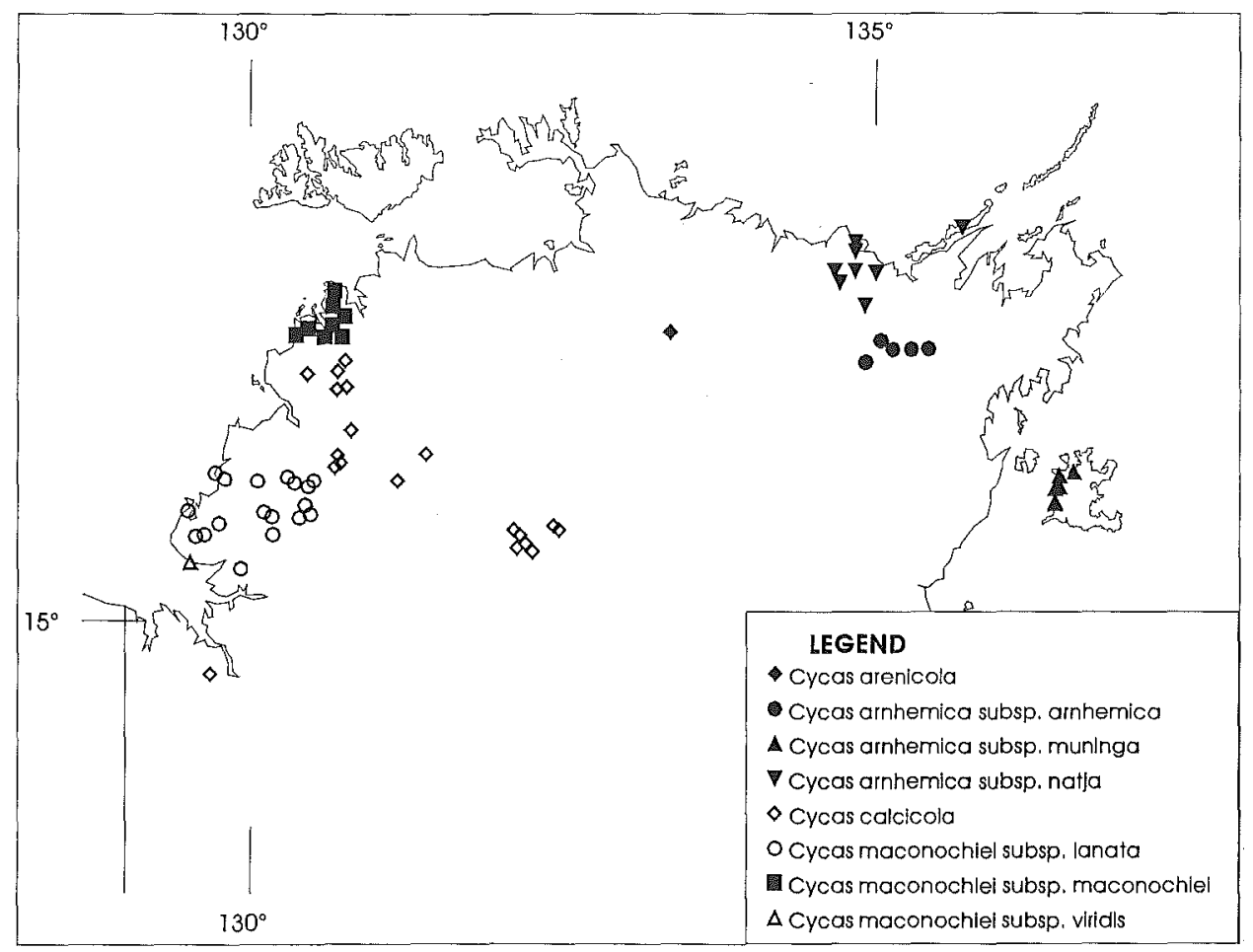

Fig. 19. Distribution of series Calcicolosae. 
21. Cycas arnhemica K.D. Hill, Telopea 5(4): 693 (1994).

Type: Northern Territory: Goyder River crossing, J.R. Maconochie 1477, 16 Jun 1977 (holo NSW; iso DNA).

Stem to $4 \mathrm{~m}$ tall, rarely to $7 \mathrm{~m}, 12-20 \mathrm{~cm}$ diam. Leaves $65-110 \mathrm{~cm}$ long, flat in section (opposing pinnae inserted at $150-180^{\circ}$ on rachis), with $120-270$ pinnae, usually terminated by a spine; petiole loosely brown- and grey- to white-tomentose, $9-36 \mathrm{~cm}$ long unarmed or spinescent for up to $50 \%$ of length; median pinnae at $45-85^{\circ}$ to rachis, 50-190 mm long, 3.0-7.5 mm wide, glabrous or loosely white- to grey-brown-tomentose, mid- to dark green, keeled in section with recurved or revolute margins, decurrent for $1.0-4.0 \mathrm{~mm}$, narrowed to $2.5-5 \mathrm{~mm}$ at base (65-100\% of maximum width), spaced at 7-13 mm on rachis, apex attenuate; midrib not or slightly raised above, prominent below. New growth densely tomentose with white and/or orange-brown trichomes. Cataphylls densely orange-brown- to grey-brown-tomentose, 3-6 cm long, fleshy. Microsporangiate cones narrow-ovoid, $18-36 \mathrm{~cm}$ long, $6.5-12 \mathrm{~cm}$ diam. Microsporophyll lamina $15-22 \mathrm{~mm}$ long, 11-17 $\mathrm{mm}$ wide; sterile apex 6-9 $\mathrm{mm}$ long, not recurved, apical spine slender, sharply upturned, 7-22 mm long. Megasporophylls 15-24 cm long, grey- and orange-tomentose, with 1-6 ovules, sterile apex $40-70 \mathrm{~mm}$ long, 15-22 $\mathrm{mm}$ wide, narrowly triangular, regularly dentate, with 10-18 lateral teeth, apical spine 7-25 $\mathrm{mm}$ long, lateral teeth $2-5 \mathrm{~mm}$ long. Seeds flattened-ovoid, green becoming orange, not pruinose, 28-37 mm long, 26-32 mm diam.; sarcotesta $2-4 \mathrm{~mm}$ thick. Figs. $20 \& 21$.

Distinguished by the flat (not keeled) leaves with relatively short petioles and keeled pinnae with somewhat recurved margins. Leaf bases and trunks retain a dense dark brown tomentum that is not evident in other taxa from Arnhem Land, and the apical spine of the microsporophylls is more attenuate. Cataphylls are also short, soft and fleshy, but lack the dense orange tomentum seen in the closely related C. maconochiei.

Three distinct populations occur, one on Groote Eylandt, another on the lower Blythe River in northern Arnhem Land, and another on the upper Goyder River in central Arnhem Land (Fig. 19). These geographically separated populations are also morphologically distinct, and are here recognised as subspecies.

\section{Key to the subspecies}

1 Pinnae 5.0-6.5 mm wide, 9-13 $\mathrm{mm}$ apart on rachis 21A. subsp. arnhemica

$1^{*}$ Pinnae 3.0-5.5 $\mathrm{mm}$ wide, $6-9 \mathrm{~mm}$ apart on rachis

2 Male cones usually more than $8 \mathrm{~cm}$ diam., seeds usually more than $32 \mathrm{~mm}$ long 21B. subsp. muninga

2* Male cones usually less than $8 \mathrm{~cm}$ diam., seeds usually less than $32 \mathrm{~mm}$ long $\ldots .$. 21C. subsp. natja

\section{A. Cycas arnhemica subsp. arnhemica}

Illustration: Hill (1994: 694, Fig. 1).

Stem to $4 \mathrm{~m}$ tall, rarely to $7 \mathrm{~m}, 12-19 \mathrm{~cm}$ diam. Leaves $65-110 \mathrm{~cm}$ long, with $120-270$ pinnae; petiole $9-36 \mathrm{~cm}$ long; median pinnae at $45-70^{\circ}$ to rachis, often falcate, $50-170 \mathrm{~mm}$ long, $5.0-7.5 \mathrm{~mm}$ wide, often loosely white-tomentose beneath, sub-glossy slightly bluish deep green, more or less keeled in section with slightly recurved margins, narrowed to $4.0-5.0 \mathrm{~mm}$ at base (65-90\% of maximum width), spaced at $7-13 \mathrm{~mm}$ on rachis. Microsporangiate cones $22-28 \mathrm{~cm}$ long, $7-9 \mathrm{~cm}$ diam. Seeds $28-33 \mathrm{~mm}$ long, 27-30 mm diam.; sarcotesta $2.5-4 \mathrm{~mm}$ thick. Figs. $20 \& 21$. 
Leaf anatomy: upper mesophyll continuous or interrupted at midrib, composed of palisade cells only; lower mesophyll interrupted at midrib, composed of equidimensional cells only; laminar hypodermis continuous, 1-2 cell layers thick; marginal hypodermis 1-2 cell layers thick; stomatal crypts deep, closed; subsidiary cells raised and differentiated; cuticle thick.

Notes: distinguished by the robust habit and the dark green leaves with relatively short petioles and well-spaced, keeled pinnae with somewhat recurved margins. The median pinnae are also distinctly angled towards the leaf apex, whereas those of subspp. muninga and natja are more nearly perpendicular to the rachis.

Distribution: locally abundant on deep white to yellow sands over laterites, in Eucalyptus tetrodonta - E. miniata dominated savanna forests around the Goyder River (Fig. 19). Plants from farther north-east (around Badalngarrmirri Creek) show glossier, paler green leaves, pinnae with a more prominent midrib on the upper surface, and a more slender habit, suggesting some intergradation with $C$. orientis. Those from farther north-west, between the Blyth and Goyder Rivers, show smaller leaves with narrower and more crowded pinnae, indicating possible intergradation with subsp. natja, which occurs on the north coast of Arnhem Land.

Conservation status: locally abundant in very remote country, not considered to be at risk.

Selected specimens: Northern Territory: Darwin \& Gulf: $13.2 \mathrm{~km}$ E of Ramangining turnoff on Gove road, Hill 3919 \& Stanberg, 25 Aug 1991 (NSW, CANB); $29.5 \mathrm{~km}$ E of Ramangining turnoff on Gove road, Hill 3920 \& Stanberg, 25 Aug 1991 (NSW); $43.5 \mathrm{~km}$ NNE of Goyder River crossing, Maconochie 1626, 22 Jun 1972 (DNA, AD); Goyder River crossing, Maconochie 1478, 16 Jun 1977 (DNA); $25.5 \mathrm{~km}$ S of Goyder River crossing, Maconochie 1466, 16 Jun 1977 (DNA, AD).

Intergrades, subsp. arnhemica - subsp. natja (1 specimen)

Northern Territory: Darwin \& Gulf: 43.8 miles [c. $70 \mathrm{~km}$ ] from Gove - Bulman Junction road on Maningrida road, Meehan 54, 9 Sep 1972 (DNA).

21B. Cycas arnhemica subsp. muninga Chirgzin $\mathcal{E}$ K.D. Hill, subsp. nov.

A subspecie typica pinnis angustioribus brevioribus aggregatioribus et marginibus recurvioribus, differt.

Type: Northern Territory: Groote Eylandt, $2 \mathrm{~km}$ S of Malgala Ck, I. Cowvie $2030 \mathcal{E}$ Brocklehurst, 11 Sep 1991 (holo NSW; iso BRI, CANB, DNA, K, MEL, PERTH).

Stem to $1.5 \mathrm{~m}$ tall, rarely to $2.5 \mathrm{~m}, 12-20 \mathrm{~cm}$ diam. Leaves $70-110 \mathrm{~cm}$ long, with $160-260$ pinnae; petiole $14-26 \mathrm{~cm}$ long; median pinnae at $65-85^{\circ}$ to rachis, $(60-70-190 \mathrm{~mm}$ long, (3.0-)4.0-5.5 mm wide, glabrous or loosely grey-brown-tomentose, glossy mid-green, keeled in section with recurved margins, narrowed to $3.0-4.5 \mathrm{~mm}$ at base $(70-100 \%$ of maximum width), spaced at $4-8 \mathrm{~mm}$ on rachis. Microsporangiate cones $25-36 \mathrm{~cm}$ long, 8-12 cm diam. Seeds 34-37 mm long, 29-32 mm diam.; sarcotesta 2-3 mm thick. Fig. 20.

Leaf anatomy: upper mesophyll interrupted at midrib, composed of palisade cells only; lower mesophyll interrupted at midrib, composed of equidimensional and palisade cells; laminar hypodermis continuous, 1 cell layer thick; marginal hypodermis 1-2 cell layers thick; stomatal crypts deep, closed; subsidiary cells undifferentiated; cuticle thick.

Notes: distinguished by the crowded and numerous green leaves with crowded, relatively short, narrow pinnae with recurved margins. Subsp. arnhenica from central Arnhem Land differs in the larger leaves with longer, wider and more widely spaced pinnae. Subsp. natja from northern Arnhem Land is distinguished by its smaller cones and seeds. This taxon has been referred to as C. species 'Grooteí in the past. 


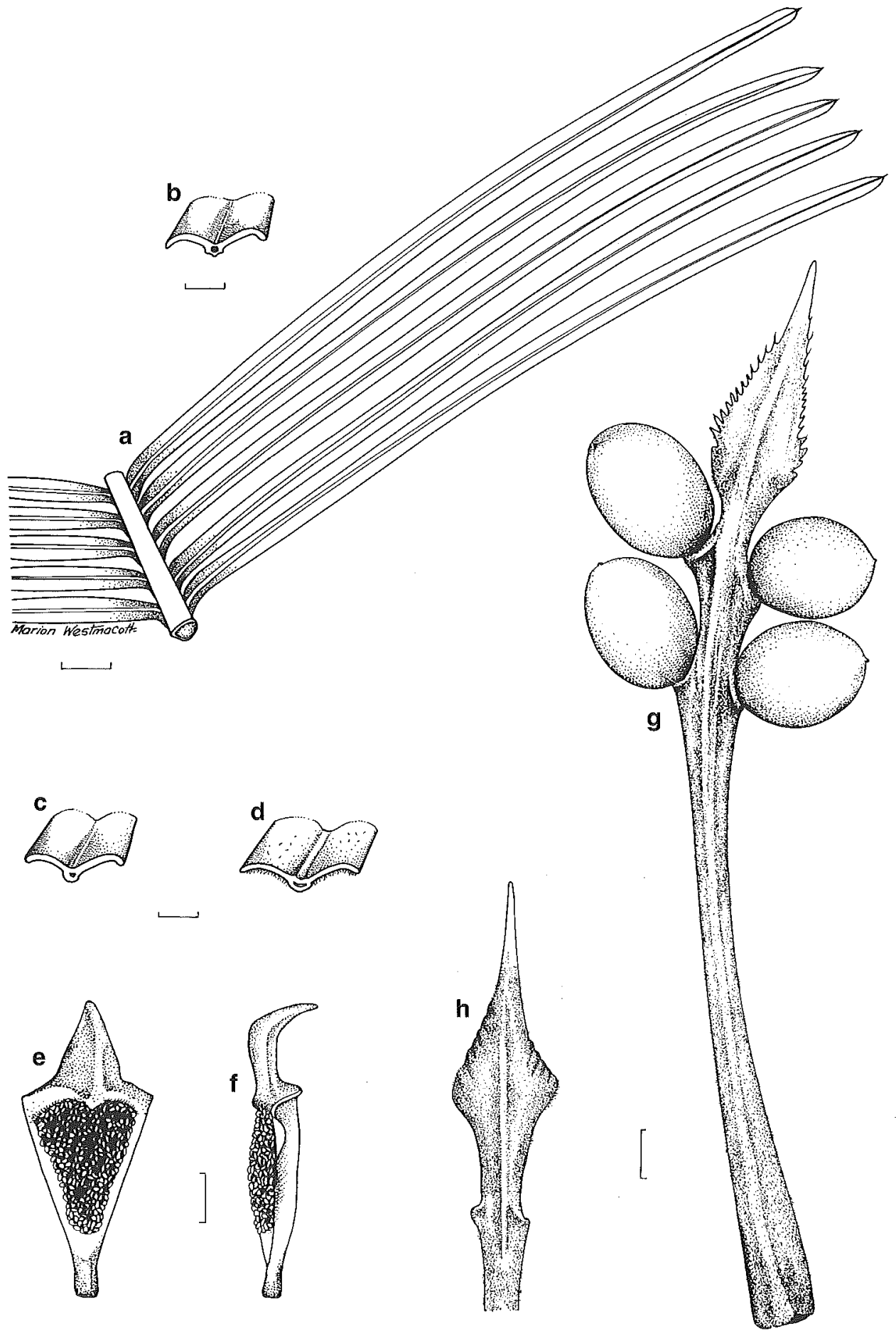

Fig. 20. C. arnhemica subsp. muninga. a, part of lelaf. $b, c, d$, sections of pinnae showing range of variation. $e, f$, microsporophyll. $g$, megasporophyll with seed and stipe. $h$, tip of megasporophyll ( $\mathrm{a}, \mathrm{b}, \mathrm{g}, \mathrm{h}$ from Levitt NT64757, c from Levitt NT36639, d, e, f from Levitt NT36640). Scale bar: $\mathrm{a}, \mathrm{g}, \mathrm{h}=1 \mathrm{~cm} ; \mathrm{b}, \mathrm{c}, \mathrm{d}=2 \mathrm{~mm} ; \mathrm{e}, \mathrm{f}=5 \mathrm{~mm}$. 
Distribution: known only from Groote Eylandt (Fig. 19), mainly on old beach dunes in near-coastal sites.

Conservation status: locally abundant, not considered to be at risk.

Etymology: the epithet is a rendering of the name for this plant in the aboriginal language of the people of Groote Eylandt.

Selected specimens: Northern Territory: Darwin \& Gulf: Mudcod Bay, Groote Eylandt, Dunlop 2955 A B C, 1 Aug 1972 (DNA, BM); Angurugu, Groote Eylandt, Levitt NT 36639, 4 Mar 1972 (DNA, AD); Levitt NT36640, NT64757 (DNA); 8 miles [12 km] from Umbakumba to Angurugu, Groote Eylandt, Levitt, 29 Mar 1972 (DNA, BRI); Wallaby Swamp Beach, Groote Eylandt, Levitt, 2 Sep 1972 (DNA); Amagula Pools on the Amagula River, Groote Eylandt, Levitt, 7 Sep 1972 (DNA); Emerald River Beach, Groote Eylandt, Levitt, 19 Sep 1972 (DNA); Groote Eylandt, Chirgwin, (NSW).

\section{C. Cycas arnhemica subsp. natja K.D. Hill, subsp. nov.}

$\mathrm{Ab}$ subspecie typica pinnis angustioribus brevioribus aggregatioribus margine recurviore, differt. Ab subspecie muninga strobili masculi parviori et semina parviori, differt.

Type: Northern Territory: Blyth River crossing, east bank, Meehan 56, 6 Sep 1972 (holo DNA).

Stem to $1.5 \mathrm{~m}$ tall, rarely to $2.5 \mathrm{~m}, 12-20 \mathrm{~cm}$ diam. Leaves $70-100 \mathrm{~cm}$ long, with $160-260)$ pinnae; petiole $12-35 \mathrm{~cm}$ long; median pinnae at $65-85^{\circ}$ to rachis, $55-120 \mathrm{~mm}$ long, $3.0-5.5 \mathrm{~mm}$ wide, glabrous, glossy mid-green, keeled in section with revolute margins, narrowed to $2.5-3.5 \mathrm{~mm}$ at base (65-100\% of maximum width), spaced at $4-9 \mathrm{~mm}$ on rachis. Microsporangiate cones $18-26 \mathrm{~cm}$ long, $6.5-8.5 \mathrm{~cm}$ diam. Seeds $28-30 \mathrm{~mm}$ long, 26-28 mm diam.; sarcotesta 2.0-2.5 mm thick. Fig. 21.

Notes: distinguished by the crowded and numerous green leaves with crowded, narrow pinnae with recurved margins. Separated from subsp. muninga by the smaller cones and seeds. Specimens from Elcho Island are slightly larger in most respects, but still do not approach subsp. muninga in size of cones and seeds. Subsp. amhemica from central Arnhem Land differs in the larger leaves with longer, wider and more widely spaced pinnae.

Distribution: known from a small area along the north coast of Arnhem Land, apparently only on the lower Blyth River on the mainland, extending to Elcho Island (Fig. 19). Intergradation with C. arnhemica occurs more inland, between the Blyth and Goyder Rivers (cited under C. arnhemica).

Conservation status: locally abundant, not considered to be at risk.

Etymology: the epithet is a rendering of the name for this species in the Bureia language of the local aboriginal people.

Selected specimens: Northern Territory: Darwin \& Gulf: $71.0 \mathrm{~km}$ from Maningrida on Ramangining road, Hill 3987 \& Stanberg, 31 Aug 1991 (NSW, CANB); $5.6 \mathrm{~km} \mathrm{~W}$ of Blyth River crossing on Ramangining-Maningrida road, Hill 3991 \& Stanberg, 1 Sep 1991 (NSW, CANB); Ramangining airstrip, Maconochie 2073, 1 Jul 1975 (DNA); Elcho Island, Maconochie 2133, 7 July 1975 (DNA, CANB, K); Njalidjibama, 3 miles [5 km] E of Blyth River, Meehan 35, 21 Aug 1972 (DNA); $16 \mathrm{~km}$ E of Blythe River on Maningrida to Ramangining road, Thomson 194, 19 Oct 1981 (DNA). 


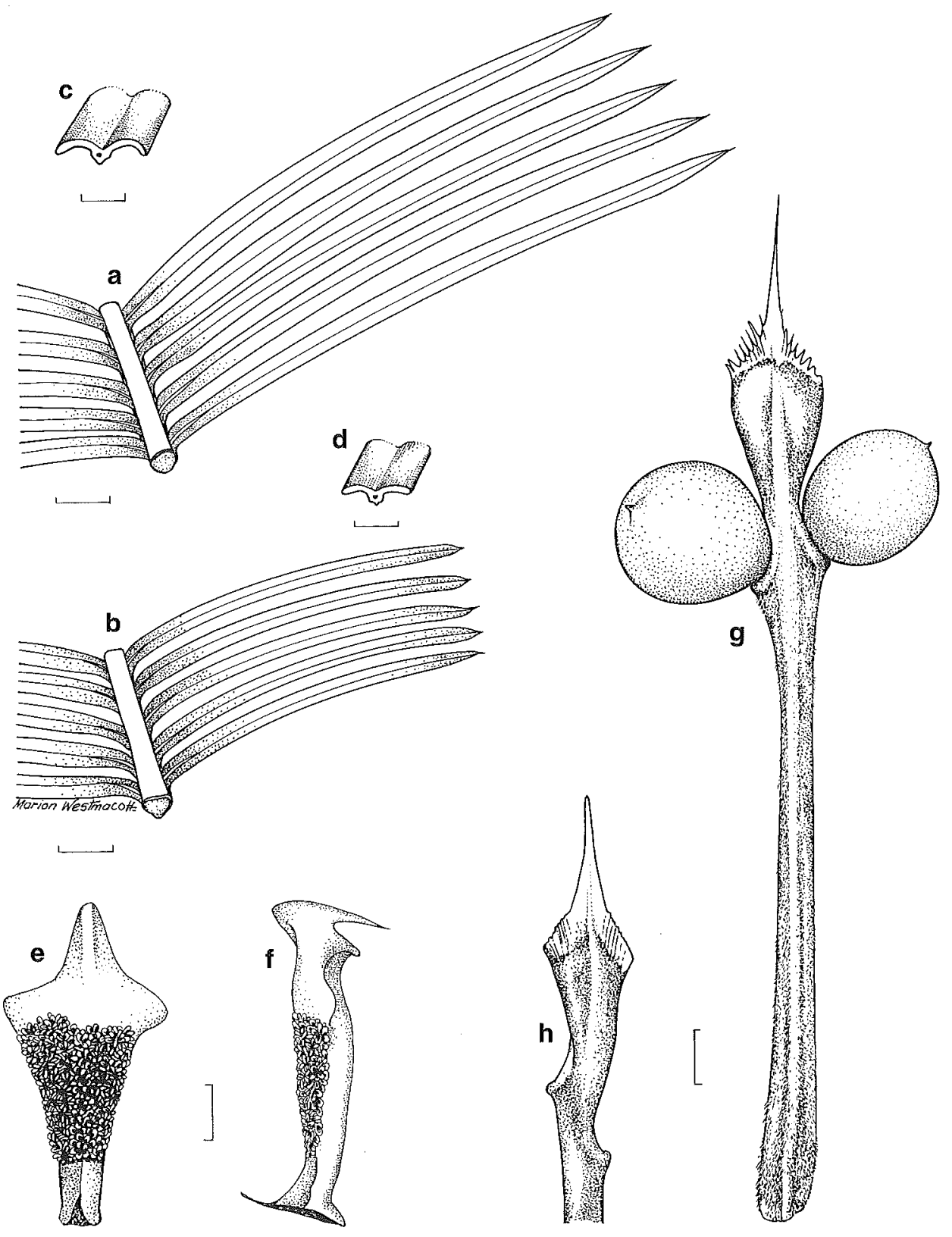

Fig. 21. C. arnhemica subsp. natja. a, b, parts of leaves. $c$, $d$, sections of pinnae. $\mathbf{e}, \mathbf{f}$, microsporophyll. $\mathrm{g}$, megasporophyll with seed and stipe. $\mathrm{h}$, tip of megasporophyll (a, c, e, f from Hill 3987, b, d, h from Thompson 194, e, f, from Hill 3987 a). Scale bar: a, b, $\mathrm{g}, \mathrm{h}=1 \mathrm{~cm} ; \mathrm{c}, \mathrm{d}=2 \mathrm{~mm} ; \mathrm{e}, \mathrm{f}=5 \mathrm{~mm}$. 


\section{Cycas maconochiei Chirgzwin \& K.D. Hill, sp. nov.}

A C. arnhemica cataphyllis indumento floccoso aurantiaco differt.

Type: Northern Territory: Mandorah road, at Bynoe Harbour turnoff, K.D. Hill $4461 \mathcal{E}$ H.M. Anderson, 4 Sep 1993 (holo NSW; iso DNA, PE, NY).

Stem to $3 \mathrm{~m}$ tall, rarely to $7 \mathrm{~m}, 9-15 \mathrm{~cm}$ diam. Leaves $70-120 \mathrm{~cm}$ long, flat to moderately keeled in section (opposing pinnae inserted at $130-180^{\circ}$ on rachis), with $140-300$ pinnae, usually terminated by a spine; petiole glabrous or loosely orange-tomentose, partly or completely spinescent or sometimes spine-free, $15-33 \mathrm{~cm}$ long; median pinnae at $60-90^{\circ}$ to rachis, $70-170 \mathrm{~mm}$ long, 3.5-7.0 mm wide, often orange-brown tomentose, more or less glaucous when new, becoming dull to glossy mid- to dark green or bluish green, flat in section with slightly to strongly recurved margins, decurrent for $1.5-3.0 \mathrm{~mm}$, narrowed to $2.5-4.5 \mathrm{~mm}$ at base (55-80\% of maximum width), usually moderately to well spaced on rachis (spaced at 5.0-10.0 mm), apex attenuate; midrib slightly raised above, prominent below. New growth densely loosely tomentose with orange and grey trichomes. Cataphylls densely tomentose with thick orange woolly trichomes, 6-8 cm long. Microsporangiate cones orange, ovoid, $20-34 \mathrm{~cm}$ long, 10-14 cm diam. Microsporophyll lamina 25-35 $\mathrm{mm}$ long, 9-12 $\mathrm{mm}$ wide; sterile apex 5-8 $\mathrm{mm}$ long, not recurved, apical spine slender, sharply upturned, 4-8 $\mathrm{mm}$ long. Megasporophylls 20-29 cm long, grey- and orange-tomentose, with 2-4 ovules, sterile apex 40-65 mm long, 14-24 mm wide, triangular, regularly dentate, with 20-36 lateral teeth, apical spine 10-20 mm long, lateral teeth 1-2 mm long. Seeds flattened-ovoid, green becoming orange, slightly pruinose, $30-36 \mathrm{~mm}$ long, 27-32 $\mathrm{mm}$ diam.; sarcotesta c. $3 \mathrm{~mm}$ thick. Figs. $22 \& 23$.

Notes: distinguished by the flattened leaves with short petioles and pinnae with recurved margins, and the basal pinnae reducing in size. Distinguished from C. arnhemica by the abundant orange-brown tomentum around the cataphylls.

Distribution: this taxon occurs in the north-west of the Northern Territory, with one population in the Cox Peninsula area west of Darwin, and a very large disjunct occurrence south of the Daly River and towards the coast (Fig. 19).

Etymology: the epithet honours the late John Maconochie, formerly botanist with the Northern Territory government, who had commenced a major revision of the genus Cycas. His work was tragically curtailed, but his notes and specimens remained, and have been invaluable in this work. These three geographically separated occurrence are recognised as subspecies.

\section{Key to the subspecies}

1 Pinnae dull bluish green, usually retaining some tomentum

2 Pinnae 5.5-7.0 mm wide, flat, margins slightly recurved, spaced at 8-10 mm on rachis 22A. subsp. maconochiei

2* Pinnae 3.5-5.5 mm wide, somewhat keeled, margins strongly recurved, spaced at $5-7 \mathrm{~mm}$ on rachis 22B. subsp. lanata

$1^{*}$ Pinnae glossy mid-green, becoming glabrous when older 22C. subsp. viridis

\section{A. Cycas maconochiei subsp. maconochiei}

Stem to $3 \mathrm{~m}$ tall, rarely to $5 \mathrm{~m}$, Leaves $70-110 \mathrm{~cm}$ long, flat in section (opposing pinnae inserted at $130-180^{\circ}$ on rachis), with $140-200$ pinnae, usually terminated by a spine; petiole spinescent for $70-100 \%$ of length, $20-30 \mathrm{~cm}$ long; median pinnae at $70-90^{\circ}$ to 
rachis, $70-150 \mathrm{~mm}$ long, $5.5-7.0 \mathrm{~mm}$ wide, grey to orange-brown tomentose, glaucous when new, becoming dull mid-green, flat in section with slightly recurved margins, narrowed to $4.0-4.5 \mathrm{~mm}$ at base (65-80\% of maximum width). Microsporangiate cones orange, ovoid, $21-34 \mathrm{~cm}$ long, 10-14 cm diam. Megasporophylls 20-25 cm. long, sterile apex $40-60 \mathrm{~mm}$ long, 18-22 mm wide, with 22-36 lateral teeth, apical spine 10-15 mm long. Seeds slightly pruinose, 33-36 mm long, 29-32 mm diam. Fig. 22.

Leaf anatomy: upper mesophyll interrupted at midrib, composed of palisade cells only; lower mesophyll interrupted at midrib, composed of equidimensional and palisade cells; laminar hypodermis continuous, 1 cell layer thick; marginal hypodermis 1 cell layer thick; stomatal crypts shallow, open to deep, closed; subsidiary cells undifferentiated; cuticle thick.

Notes: This taxon is known and distributed in cultivation as C. species 'Bynoeí, C. species 'Bynoe Harbourí, C. species 'Fog Bay, C. species 'Cox Peninsula

Distribution: subsp. maconochiei is restricted to a small area between Fog Bay and Port Darwin, to the south-west of Darwin (Fig. 19). It occurs in open savanna forests on flat sites dominated by Eucalyptus miniata and E. tetrodonta on sandy soil over Tertiary laterites. Apparent hybrids are known with C. armstrongii.

Conservation status: locally extremely abundant, not considered to be at risk. Although not reserved, the extreme abundance of this species would buffer it from any threat in the medium term. Seed and plant collectors may pose a problem in the future, in particular when frequent fire also effectively blocks reproduction and uncontrolled development alienates significant proportions of the habitat.

Selected specimens: Northern Territory: Darwin \& Gulf: near house Lot 176, Pularumpi, Garden Point, Melville Island, Bishop s.n., 13 Oct 1993 (NSW); near barge landing, Pularumpi, Garden Point, Melville Island, Bishop s.n., 13 Oct 1993 (NSW); 27.7 km on Finniss station Road from Bynoe Road turn-off, Browon s.n., 8 Aug 1990 (DNA, NSW); Bynoe Harbour, Chirgwin s.n., 20 Mar 1988 (NSW); Melville Island, Dunlop 3455, 18 Apr 1973 (NSW, DNA, NT, BRI, CANB); Leviathan Creek, on Fog Bay road, Hill 4459 \& Anderson, 4 Sep 1993 (NSW, DNA, BRI, CANB); Fog Bay, behind beach, Hill 4460 \& Anderson, 4 Sep 1993 (NSW, DNA, CANB, K); Delissaville, Must s.n., Sep 1972 (DNA, CANB);

\section{B. Cycas maconochiei subsp. lanata $K$. Hill, subsp. nov.}

A subspecie typica pinnis angustioribus impolitis marginibus recurvioribus, sub maturitatem tomentosis, differt.

Type: Northern Territory: $25 \mathrm{~km}$ E of Port Keats, J.R. Maconochie 2498, 11 Oct 1980 (holo DNA; iso CANB, K).

Stem to $3 \mathrm{~m}$ tall, rarely to $7 \mathrm{~m}, 9-14 \mathrm{~cm}$ diam. Leaves $70-120 \mathrm{~cm}$ long, moderately keeled in section (opposing pinnae inserted at $130-160^{\circ}$ on rachis), with $160-230$ pinnae, usually terminated by a spine; petiole spinescent for $10-100 \%$ of length, $18-33 \mathrm{~cm}$ long; median pinnae at $60-80^{\circ}$ to rachis, $90-150 \mathrm{~mm}$ long, $3.5-5.5 \mathrm{~mm}$ wide, orange-tomentose and slightly glaucous when new, becoming glabrous above and semiglossy mid- to deep green, margins recurved, narrowed to $2.5-3.5 \mathrm{~mm}$ at base (55-75\% of maximum width). Microsporangiate cones $22-33 \mathrm{~cm}$ long, $11-14 \mathrm{~cm}$ diam. Megasporophylls 23-27 cm long, sterile apex 50-60 $\mathrm{mm}$ long, 14-20 mm wide, with 20-30 lateral teeth, apical spine 10-15 mm long. Seeds not pruinose, 30-35 mm long, 27-32 mm diam. Fig. 22.

Notes: distinguished by the narrow pinnae with more strongly recurved margins, and the thickly woolly cataphylls. Subsp. maconochiei from farther north differs in the broader, flatter and more widely spaced pinnae, and the somewhat less densely tomentose cataphylls, and subsp. viridis from farther west has broader pinnae that are glossy green. Both subsp. maconochiei and subsp. lanata have a more or less persistent 


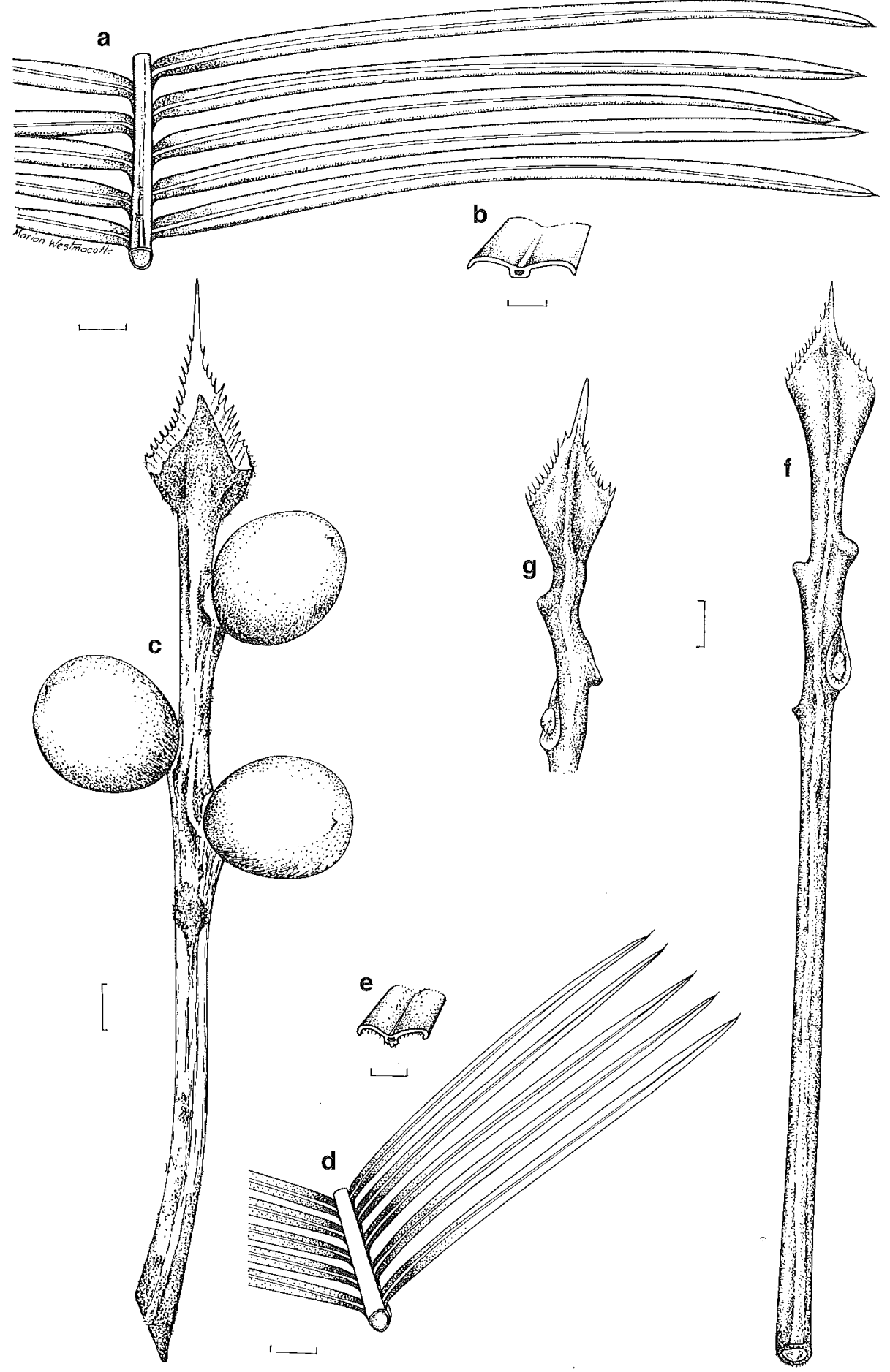

Fig. 22. C. maconochiei subsp. maconochiei. a, part of leaf. $\mathbf{b}$, section of pinna. $\mathbf{c}$, megasporophyll with seed and stipe. (from Brown 8 Aug 1990). Scale bar; $a, c=1 \mathrm{~cm} ; b=2 \mathrm{~mm}$. C. naconochiei subsp. lanata. $\mathrm{d}$, part of leaf. e, section of pinna. $\mathrm{f}$, megasporophyll with seed and stipe. $\mathrm{g}$, tip of megasporophyll (from Maconochie 2498). Scale bar: d, $\mathrm{f} g=1 \mathrm{~cm}$; $\mathrm{e}=2 \mathrm{~mm}$.). 
indumentum on the leaves, that of subsp. maconochiei is usually light orange-brown or even paler, whereas that of subsp. lanata is a darker red-brown. Tomentum is less persistent and eventually lost in subsp. viridis. Subsp. lanata varies markedly in stature across its range, in particular in that plants from the north-west of the range (around Nardirri) are consistently very much smaller, although similar in all other attributes. This taxon is known and distributed in cultivation as C. species 'Port Keatsí.

Distribution: widespread and in parts extremely abundant, usually on sandy soils. Known only from the northern Wingate Mountains and adjacent plains country to the north and west, extending to the coast north of Peppimenarti, and west almost to Port Keats (Fig. 19). Initial estimates suggest that the total population of this subspecies would number into the tens of millions.

Conservation status: abundant and widespread, not considered to be at risk. Although not reserved, the extreme abundance of this species would buffer it from any threat in the medium term. Almost all populations are on aboriginal land, and conservation issues on such land are yet to be fully addressed. The inhibition of reproduction by too-frequent fire is one such issue.

Etymology: the epithet is from the Latin lanatus, woolly, in reference to the densely tomentose cataphylls.

Selected specimens: Darwin \& Gulf: Northern Territory: road to Woodycupuldea, Hill 4464 \& Pemer, 5 Sep 1993 (NSW, DNA, NY, PE); Peppimenarti, Hill 4478 \& Perner, 6 Sep 1993 (NSW); Woodycupuldea - Peppimenarti road, Hill 4465 \& Pemer, 5 Sep 1993 (NSW); road to beach N of Nardirri, Hill 4466 \& Perner, 6 Sep 1993 (NSW, DNA, CANB, BRI); Old Mission, Port Keats, Hill 4484 \& Perner, 7 Sep 1993 (NSW); track from Palumpa to Mudjilindi Valley, over Macadam Range, Hill 4495 \& Pemer, 8 Sep 1993 (NSW); edge of plain near Emu Point, Hill 4046 \& Stanberg, 10 Sep 1991 (NSW); plain to N of Wingate Mountains, Hill 4056 \& Stanberg, 10 Sep 1991 (NSW, CANB); Daly River - Port Keats road, Hill 4057 \& Stanberg, 10 Sep 1991 (NSW); Moyle River, $75 \mathrm{~km}$ E of Port Keats, Latz 13795 \& Dunlop, 10 May 1994 (NSW, NSW); c. 20 km E of Port Keats, Maconochie 2497, 11 Oct 1980 (DNA, BRI, CBG); $25 \mathrm{~km}$ E of Port Keats, Maconochie 2498, 11 Oct 1980 (DNA, CANB, K); $40 \mathrm{~km} \mathrm{~W}$ of Daly River crossing on Port Keats road, Pemer s.n., May 1993 (NSW, BRI, CANB, DNA).

Intergrades, subsp. lanatus - subsp. viridis

Darwin \& Gulf: Northern Territory: Old Mission, Port Keats, Hill 4484 \& Perner, 7 Sep 1993 (NSW).

\section{C. Cycas maconochiei subsp. viridis $K$. Hill, subsp. nov.}

A subspecie typica pinnis latioribus nitentioribus marginibus recurvioribus, sub maturitatem glabrescentibus; cataphylla indumento floccoso aurantiaco, differt.

Type: Northern Territory: Fossil Head, K.D. Hill 4489 \& J. Perner, 7 Sep 1993 (holo NSW).

Stem to $4 \mathrm{~m}$ tall, rarely to $6 \mathrm{~m}, 12-16 \mathrm{~cm}$ diam. Leaves $80-120 \mathrm{~cm}$ long, moderately keeled in section (opposing pinnae inserted at $130-160^{\circ}$ on rachis), with $160-300$ pinnae, usually terminated by a spine 3-11 mm long; petiole unarmed or spinescent for up to $90 \%$ of length, $15-26 \mathrm{~cm}$ long; median pinnae at $60-80^{\circ}$ to rachis, $85-170 \mathrm{~mm}$ long, $4.0-5.5 \mathrm{~mm}$ wide, orange-tomentose and slightly glaucous when new, becoming glabrous glossy mid- to deep green, margins recurved, narrowed to $2.5-3.5 \mathrm{~mm}$ at base $(55-75 \%$ of maximum width). Microsporangiate cones not seen. Megasporophylls 22-29 cm long, sterile apex 45-65 mm long, 17-24 mm wide, with 24-32 lateral teeth, apical spine 10-20 mm long. Seeds not pruinose, 34-36 mm long, 30-32 mm diam. Fig. 23.

Notes: distinguished by the relatively broad, glossy green pinnae with recurved margins, and the thickly woolly cataphylls. Subsp. maconochiei from some distance farther north differs in the dull, flatter and more widely spaced pinnae, and the less densely tomentose cataphylls. Subsp. lanata, adjacent to the north and east, has narrower, dull pinnae. 
Distribution: scattered and locally abundant, usually on sandy soils or on old beach sands. Known only from around Fossil Head (Fig. 19).

Conservation status: not considered to be at risk. Although not reserved, the remote occurrence of this subspecies would buffer it from any threat in the medium term. All populations are on aboriginal land, and conservation issues on such land are yet to be fully addressed. The inhibition of reproduction by too-frequent fire is one such issue.

Etymology: The epithet is from the Latin viridis, green, in reference to the bright green leaves.

Selected specimens: Northern Territory: Darwin \& Gulf: Fossil Head, Perner s.n., May 1993 (NSW, BRI, CANB, DNA).

23. Cycas arenicola K.D. Hill, Telopea 5(2): 419 (1993).

Type: Northern Territory: upper East Alligator River (12 $\left.48^{\prime} \mathrm{S} 133^{\circ} 21^{\prime} \mathrm{E}\right)$, J. Russell-Smith $8502 \mathcal{E}$ J. Brock, 7 Sep 1991 (holo NSW; iso DNA).

Illustration: Hill (1993: 420, Fig. 1).

See Hill (1993) for description and specimen citations.

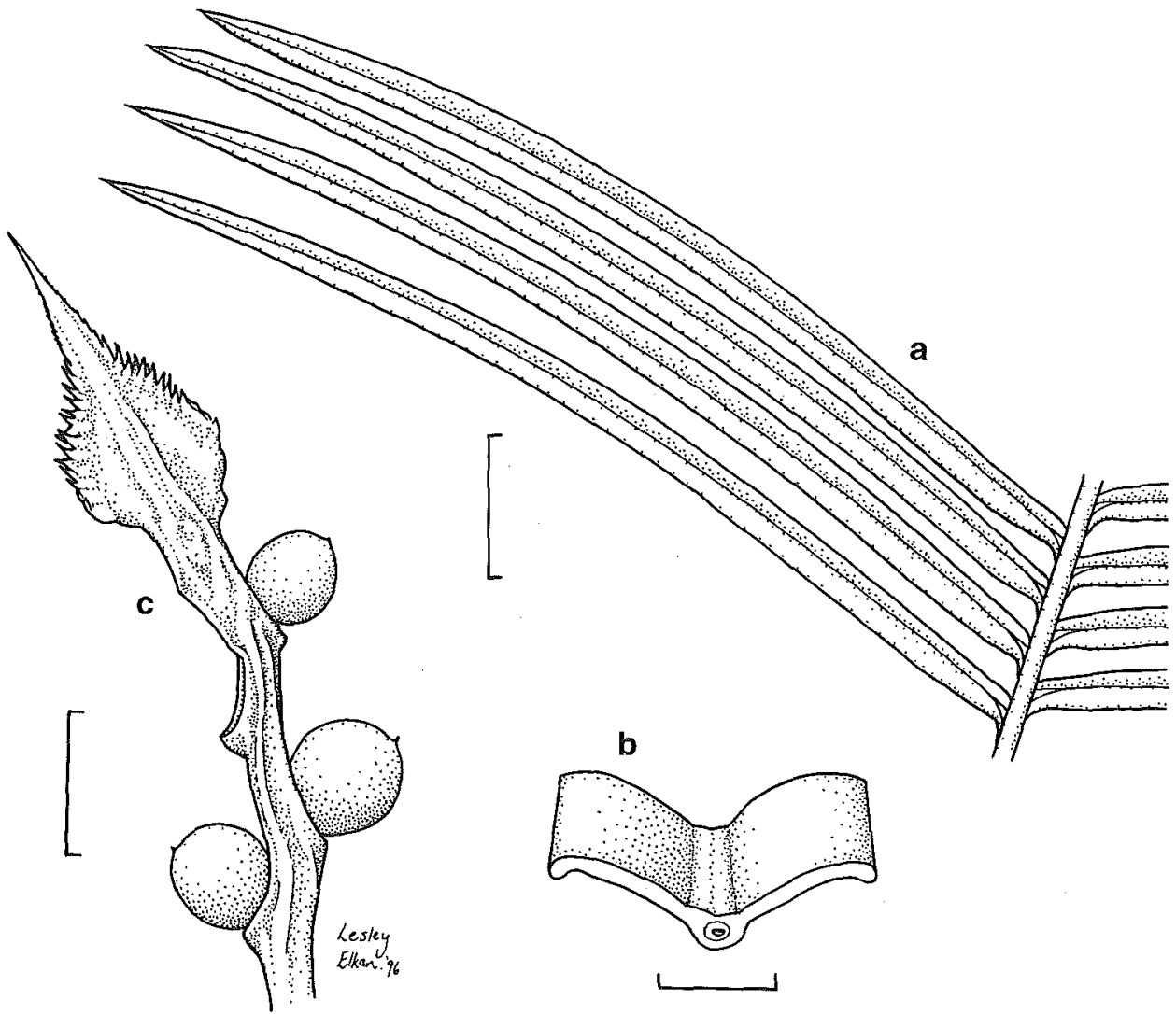

Fig. 23. C. maconochiei subsp. viridis. $\mathbf{a}$, part of leaf. $\mathbf{b}$, section of pinna. $\mathbf{c}$, megasporophyll with seed and stipe (from Hill 4489). Scale bar: $\mathrm{a}, \mathrm{c}=1 \mathrm{~cm} ; \mathrm{b}=2 \mathrm{~mm}$. 
Leaf anatomy: upper mesophyll continuous or interrupted at midrib, composed of palisade cells only; lower mesophyll interrupted at midrib, composed of equidimensional cells only; laminar hypodermis continuous, 1-2 cell layers thick; marginal hypodermis 1-2 cell layers thick; stomatal crypts deep, closed; subsidiary cells raised and differentiated; cuticle very thick.

Notes: distinguished among Australian species by the non-keeled leaves, the fusiform to elongate-ovoid microsporangiate cones, and the narrow, non-glaucous pinnae with recurved margins and persistent brown tomentum beneath. This species is most similar to C. calcicola Maconochie, also from the Northern Territory, sharing the small, narrow microsporangiate cone and the persistent tomentum on the undersurfaces of the pinnae, but differing in having fewer pinnae per leaf (180-270), and wider pinnae (4.0-6.5 mm wide) which taper more gradually to the apex and are less crowded (spaced at 8-14 mm on the rachis). C. pruinosa Maconochie from Western Australia has narrow pinnae with recurved margins and a narrow microsporangiate cone, but the pinnae of $C$. arenicola are not glabrous at maturity and the cones are much shorter (c. $25 \mathrm{~cm}$ long). No other Australian species shares the persistent tomentum on the undersurfaces of the pinnae. In addition, all Australian species except $C$. arenicola, C. calcicola and C. pruinosa have more nearly ovoid microsporangiate cones.

Distribution: C. arenicola occurs on sandy soils on screes derived from siliceous sandstone in rugged and broken country of the upper reaches of the East Alligator and Liverpool Rivers (Fig. 19). This species has rarely been collected, and is likely to be more widely distributed.

\section{Cycas calcicola Maconochie, J. Adelaide Bot. Gard. 1(3): 175 (1978).}

Type: Northern Territory: $16 \mathrm{~km}$ N of Katherine, J.R. Maconochie 1314, 10 June 1971 (holo NT; iso BRI, CANB, K, L, PERTH).

Illustration: Maconochie (1978: 176, Fig. 1). Elliot \& Jones (1984: 148).

Stem to $2.0 \mathrm{~m}$ tall, rarely to $4 \mathrm{~m}, 16-22 \mathrm{~cm}$ diam. Leaves $60-130 \mathrm{~cm}$ long, flat in section (opposing pinnae inserted at $180^{\circ}$ on rachis), with $210-410$ pinnae; petiole densely grey-white-tomentose, $18-30 \mathrm{~cm}$ long, spinescent, for $10-50 \%$ of length; median pinnae at $70-90^{\circ}$ to rachis, $50-120 \mathrm{~mm}$ long, $2.5-4.0$, rarely $5.0 \mathrm{~mm}$ wide, brown-white tomentose above, becoming glabrous, glossy, slightly bluish deep green (not glaucous), densely brown-white-tomentose beneath, slightly keeled in section with revolute margins, decurrent for $0-1.5 \mathrm{~mm}$, narrowed to $2.5-4.0 \mathrm{~mm}$ at base (90-100\% of total width), closely spaced on rachis (spaced at 4-6 $\mathrm{mm}$ ), apex attenuate; midrib not raised above, prominent below. New growth densely tomentose with grey-white and few orange trichomes. Cataphylls densely grey-white-tomentose, 3-6 cm long. Microsporangiate cones fusiform, 25-30 cm long, 5-7 cm diam. Microsporophyll lamina 18-20 mm long, 8-10 mm wide; sterile apex 8-10 mm long, not recurved, apical spine slender, sharply upturned, 7-10 $\mathrm{mm}$ long. Megasporophylls $12-18 \mathrm{~cm}$ long, grey- and orange-tomentose, with 4-6 ovules, sterile apex $20-25 \mathrm{~mm}$ long, $15-20 \mathrm{~mm}$ wide, narrowly triangular, regularly dentate, with 26-36 lateral teeth, apical spine 6-10 $\mathrm{mm}$ long, lateral teeth 2-4 mm long, c. $1 \mathrm{~mm}$ wide. Seeds flattened-ovoid, green becoming orange, strongly glaucous, 28-31 mm long, 27-30 mm diam.; sarcotesta 2.5-3 mm thick. Fig. 24.

Leaf anatomy: upper mesophyll continuous or interrupted at midrib, composed of palisade and equidimensional cells; lower mesophyll interrupted at midrib, composed of equidimensional cells only; laminar hypodermis continuous, 1-2 cell layers thick; marginal hypodermis 1-2 cell layers thick; stomatal crypts deep, closed; subsidiary cells raised and differentiated; cuticle very thick. 
Notes: distinguished by the flat leaves with very large numbers of very narrow pinnae that are persistently tomentose below, and the slender male cones.

Distribution: abundant around the Daly River basin and north along the Finniss Range, from Katherine in the south-east to the north of Litchfield Park, and south to near the Daly River Police station (Fig. 19). Although originally described from limestone and named accordingly, this species occurs on various often non-calcareous substrates such as sandstones, sandy alluvium and aluminous schists.

Conservation status: widespread, not considered to be at risk.

Selected specimens: Northern Territory: Darwin \& Gulf: $600 \mathrm{~m}$ E of Daly River police station, Brown, 20 Dec 1987 (DNA); Blackfellows Creek, Byrnes 1240, 18 Dec 1968 (DNA); 8 miles [12 km] NE of Wangi homestead, Byrnes 1677, 26 Aug 1969 (DNA); 10.9 miles [17km] N of Katherine,

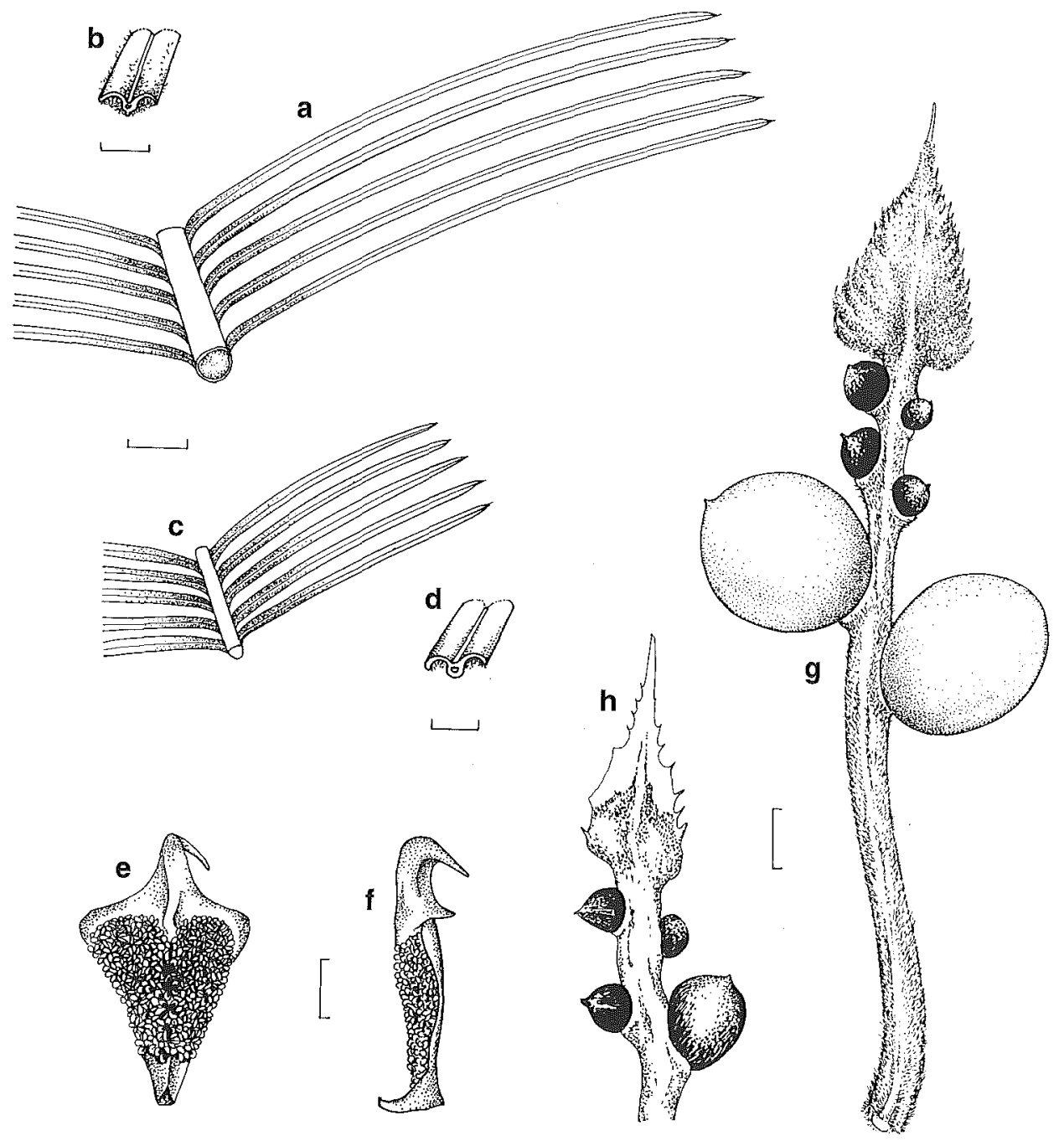

Fig. 24. C. calcicola. a, $c$, parts of leaves. $b$, d, sections of pinnae. e, $f$, microsporophyll. $g$, megasporophyll with seed and stipe. h, tip of megasporophyll (a, b, e, f from Hill 3967, c, d, g from Hill 4032, h from Hill 3967a). Scale bar: a, c, g, $h=1 \mathrm{~cm} ; \mathrm{b}, \mathrm{d}=2 \mathrm{~mm} ; \mathrm{e}, \mathrm{f}=5 \mathrm{~mm}$. 
Chippendale NT 3741, 10 Sep 1957 (DNA, NSW); Katherine experiment farm, c. 8 miles [12 km] N of Katherine, Everist 9257, 18 Sep 1969 (BRI); 12.9 km from . The Lost City, Litchfield Park, Hill 3331 Johnson \& Stanberg., 16 Nov 1988 (NSW); $10 \mathrm{~km}$ N of Katherine, Hill 3967, a \& Stanberg, 27 Aug 1991 (NSW, CANB); $12.1 \mathrm{~km}$ from Labelle Downs turnoff on Litchfield Park road, Hill 4032 \& Stanberg, 8 Sep 1991 (NSW); $18 \mathrm{~km}$ N of Katherine on Stuart Hwy, Jacobs 1911, 9 Jun 1974 (NSW); 8.5 miles [13 km] NW of low level crossing, Katherine, Lazarides 6624, 9 Jul 1961 (CANB, DNA); Mt Briggs, Fish River station, Leach 2513 \& Dunlop, 16 Mar 1989 (DNA); Bamboo Creek, Mandorah road, Maconochie 2069, 16 May 1975 (DNA, BRI, K); $3 \mathrm{~km} \mathrm{~W}$ of Mt Muriel, Tipperary station, Russell-Smith \& Brock 7896, 16 Mar 1989 (DNA). Victoria River: Spirit Hills, Bullo River Station, Dunlop 10161 \& Walsh, 9 May 1995 (DNA, NSW).

Series Furfuraceosae K.D. Hill, series nov.

Inter series subsectionis Endemicae combinatione pinnis inferis gradatim decrescentibus vel spinescentibus, margine plus minusve revoluto; cataphylla non pungentia; strobili masculi aliquantum parvi fusiformes vel angusti ovoidei brunnei vel ferruginei; megasporophylla lamina angusta triangulari dentata, dentibus non pungentibus, distinguitur.

Type species: Cycas furfuracea W. Fitzgerald.

Microsporangiate cone narrowly ovoid to fusiform, orange-brown to brown; megasporophyll lamina narrowly triangular, lateral teeth not pungent; leaves consistently terminated by paired pinnae; basal pinnae gradually reducing to spines; cataphylls soft, not pungent. Upper mesophyll continuous or interrupted at midrib, with a distinct basal layer of equidimensional cells; lower mesophyll interrupted at

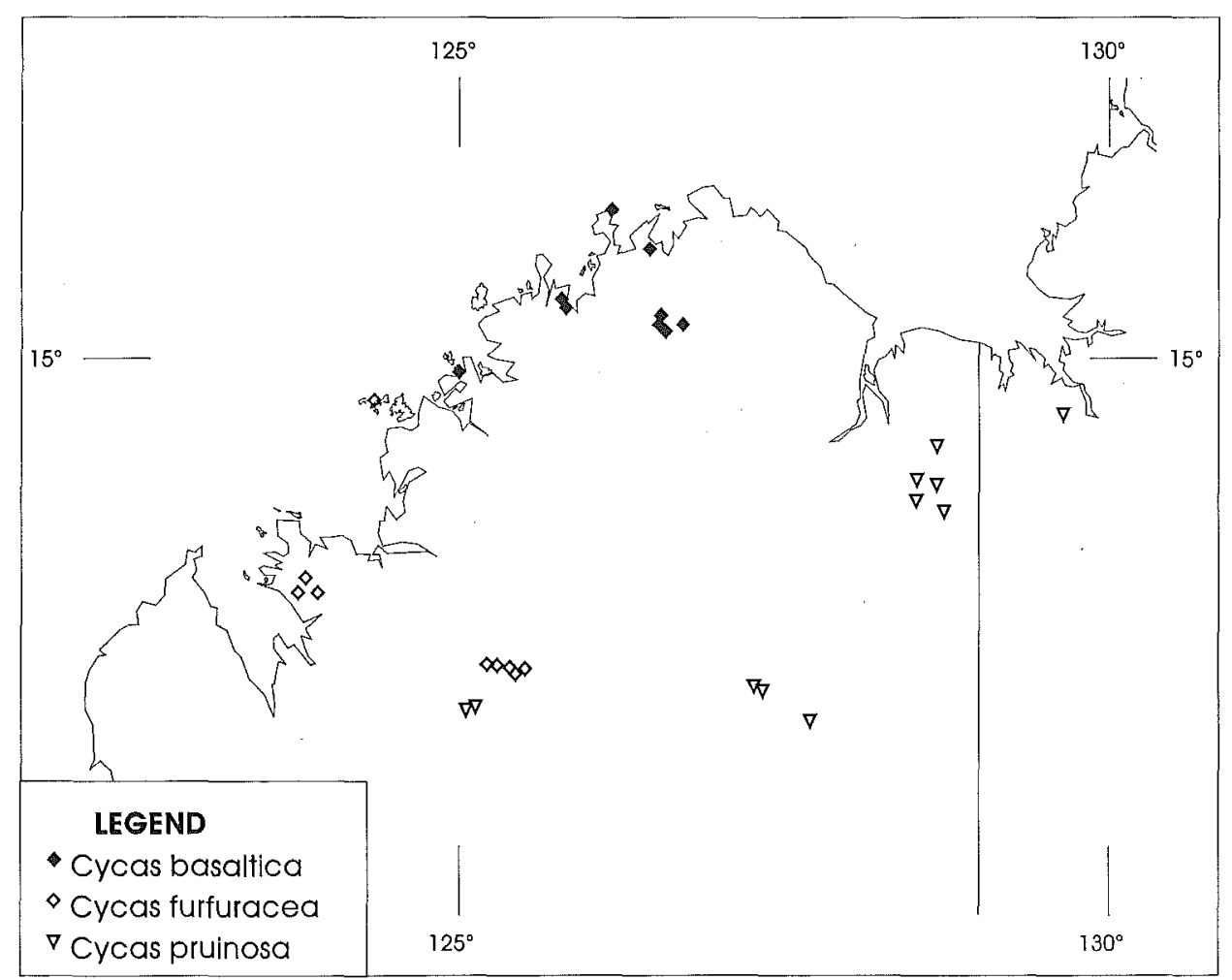

Fig. 25. Distribution of series Furfuraceosae. 
midrib, with well-developed palisade cells; laminar hypodermis continuous or abundant but discontinuous, stomatal crypts deep, closed; subsidiary cells raised and differentiated; cuticle thick.

This series of three species is restricted to the Kimberley region of Western Australia (Fig. 25).

25. Cycas furfuracea W. Fitzgerald, J. \& Proc. Roy. Soc. Western Australia 3: 108 (1918).

Cycas media R. Brown var. furfuracea (W.Fitzgerald) Schuster, Pflanzenr. 99: 78 (1932).

Type: Western Australia: summit of Mount Herbert, King Leopold Ranges, W.V. Fitzgerald 793, May 1905 (lecto NSW; isolecto PERTH).

Stem to $1.5 \mathrm{~m}$ tall, rarely to $2.5 \mathrm{~m}, 18-22 \mathrm{~cm}$ diam. Leaves $80-150 \mathrm{~cm}$ long, keeled in section (opposing pinnae inserted at $40-70^{\circ}$ on rhachis), with $100-220$ pinnae, consistently terminated by paired pinnae; petiole loosely white-tomentose, $15-26 \mathrm{~cm}$ long, spinescent, for $5-50 \%$ of length (often with only 2 or 3 distal spines); median pinnae at $40-50^{\circ}$ to rhachis, $70-200 \mathrm{~mm}$ long, $6.5-7.5 \mathrm{~mm}$ wide, more or less grey- white tomentose, particularly beneath, flat or slightly keeled in section with margins slightly recurved, decurrent for 3-7 mm, narrowed to $4.5-6.0 \mathrm{~mm}$ at base (c. $80 \%$ of maximum width), spaced at 9-13 $\mathrm{mm}$ on rhachis, apex attenuate; midrib raised above, prominent below. New growth densely tomentose with grey-white trichomes. Cataphylls densely white and pale orange-brown-tomentose, $4-8 \mathrm{~cm}$ long. Microsporangiate cones broadly fusiform, pale brown, $30-40 \mathrm{~cm}$ long, 7-9 $\mathrm{cm}$ diam. Microsporophyll lamina $20-25 \mathrm{~mm}$ long, 16-20 $\mathrm{mm}$ wide; sterile apex $12-18 \mathrm{~mm}$ long, recurved, apical spine slender, sharply upturned, 6-12 mm long. Megasporophylls 26-36 cm long, grey- and pale orangebrown-tomentose, with $4-8$ ovules, sterile apex $70-95 \mathrm{~mm}$ long, $10-22 \mathrm{~mm}$ wide, narrowly triangular, regularly dentate, with 12-20 lateral teeth, apical spine 25-65 mm long, lateral teeth 2-5 mm long, 2-3 mm wide. Seeds flattened-ovoid, green becoming yellow, pruinose, 32-36 mm long, 27-32 mm diam.; sarcotesta 2-3 mm thick. Fig. 26.

Leaf anatomy: upper mesophyll interrupted at midrib, composed of palisade and equidimensional cells; lower mesophyll interrupted at midrib, composed of equidimensional and palisade cells; laminar hypodermis continuous, 1-2 cell layers thick; marginal hypodermis 2 cell layers thick; stomatal crypts deep, closed; subsidiary cells raised and differentiated; cuticle thick.

Typification: collection data was cited as 'Summits of Mts. Herbert, Broome, and Bold Bluff (W.V.F.).' No type was designated, and the collection cited above is apparently the only extant Fitzgerald collection of this species. The specimens in both NSW and PERTH include a leaf portion, together with both male and female sporophylls, and so must have been gathered from more than one plant. The leaf section in NSW is here designated the lectotype. The leaf sections in NSW and PERTH can be matched at the break, and so are from the same leaf. The NSW portion, however, includes part of the petiole and the lower pinnae, which are specifically mentioned in the protologue. The leaf is chosen as lectotype in preference to the sporophylls because it is the most distinctive feature of this species.

Notes: distinguished by the strongly keeled leaves with angled, broad, often white-tomentose, glaucous pinnae with slightly recurved margins. The leaves are consistently terminated by paired pinnae, and pinnae gradually reduce in size to grade into spines on a short petiole in both $C$. furfuracea and $C$. basaltica. Microsporangiate cones are also relatively long and narrow in this species, and somewhat broader in C. basaltica. Sporadic individuals also lack the glaucous leaf wax, leading to the occasional occurrence of green plants in stands of otherwise blue plants (similar occurrences are present in C. pruinosa, which see). Leaves of the western 
occurrences (on Kimbolton) tend to lose their tomentum as they mature, whereas the tomentum may persist for several years on leaves of the plants in the King Leopold Range. The western occurrences also tend to have broader pinnae than those occurring in the King Leopold Ranges. The ranges of both characters in the two populations overlap substantially, and no clear infraspecific division can be recognised.

Distribution: a sporadic species in the Kimberley region of Western Australia, known mainly from elevated parts of the King Leopold Range, with another occurrence on
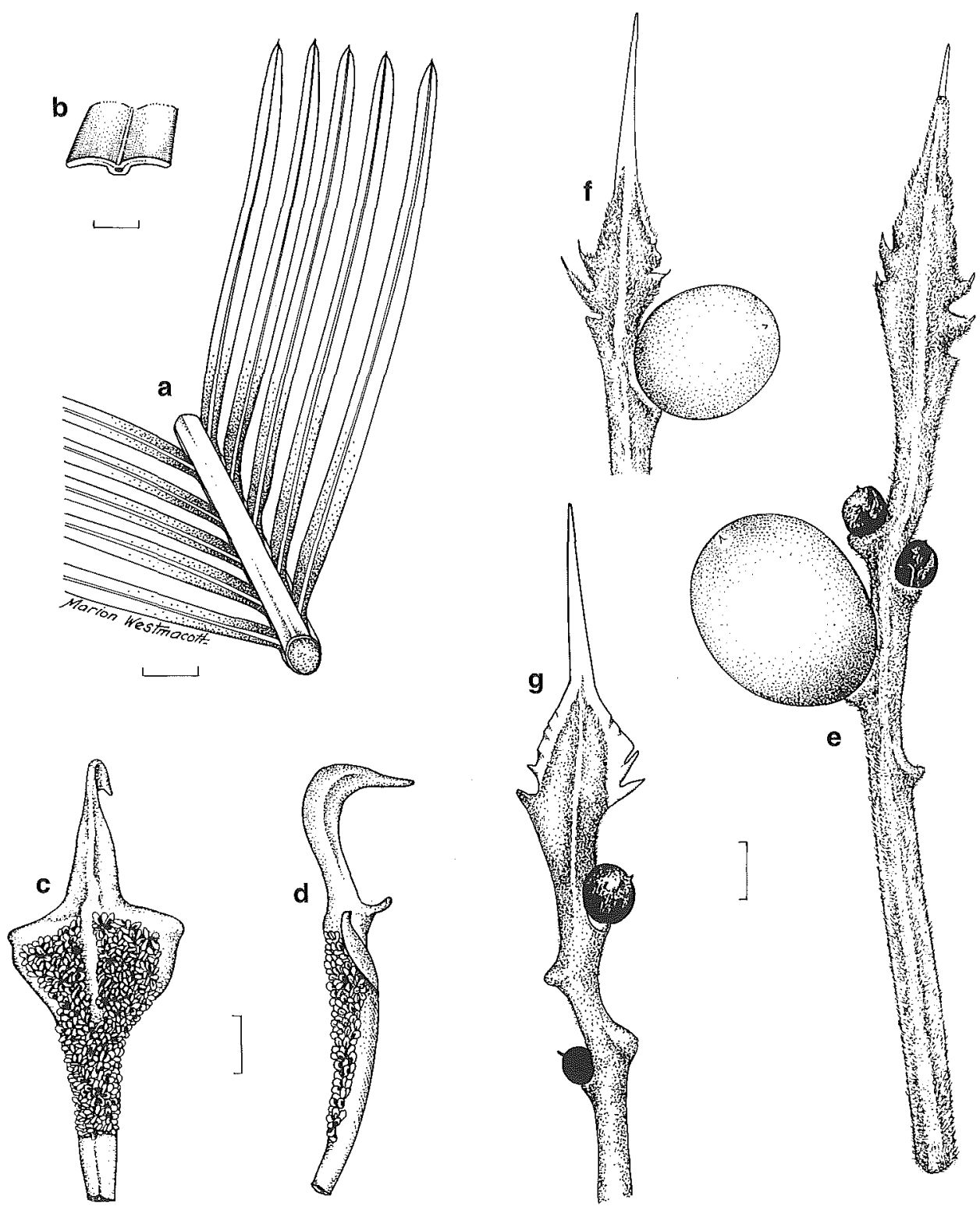

Fig. 26. C. furfuracea a, part of leaf. b, section of pinna. $c$, d, microsporophyll. e, megasporophyll with seed and stipe. $\mathrm{f}, \mathrm{g}$, tip of megasporophyll (a, b, c, d from Hill 4114, e from Hill 4110, f from Wilson 280, $\mathrm{g}$ from Hill $4114 a$ ). Scale bar: $\mathrm{a}, \mathrm{e}, \mathrm{f}, \mathrm{g}=1 \mathrm{~cm} ; \mathrm{b}=2 \mathrm{~mm} ; \mathrm{c}, \mathrm{d}=5 \mathrm{~mm}$. 
Kimbolton and on islands to the north of there, such as Heywood Island (Fig. 25). Usually on skeletal sandy soils on hard siliceous metasandstone, on steep slopes. The occurrences at Kimbolton are unusual in being both on similar substrates to the above, and also on red clay on rocky basalt outcrops.

Selected specimens: Western Australia: Fitzgerald: summit of Mt Herbert, Fitzgerald 793, May 1905 (NSW); slopes of Bold Bluff, Gittins 1444, Jul 1967 (NSW); Brownrigg Gorge, Hill 4114 \& Stanberg, 21 Sep 1991 (NSW, CANB); northern face of Bold Bluff, King Leopold Range, Maconochie 1196, 26 May 1971 (DNA, BRI, K, L); head of Brownrigg Gorge, Peter Wilson 279, 280, 21 May 1988 (NSW); Stuart River, c. 18 km N of Kimbolton homestead, K.D. Hill 4110 \& L.C. Stanberg, 20 Sep 1991 (NSW, CANB); Stewart River Valley, 13 km NNW of Kimbolton homestead, Telford 6312, 66313 \& Butler, 31 July 1977 (CBG); Heywood Island, Bonaparte Archipelago, Wilson 10888, 21 May 1972 (PERTH, DNA).

26. Cycas basaltica C.A. Gardner, Bull. Woods Forests Dept., Western Australia 32: 31 (1923).

Cycas media R. Brown var. basaltica (C.A. Gardner) Schuster, Pflanzenr. 99: 78 (1932).

Type: Western Australia: Lawley River, Kimberley, C.A. Gardner 1490, 27 July 1921 (holo PERTH). Cited as 'The type is 1490, of the Forests Department Herbarium.'

Stem to $2 \mathrm{~m}$ tall, rarely to $4 \mathrm{~m}, 15-23 \mathrm{~cm}$ diam. Leaves $80-125 \mathrm{~cm}$ long, flat in section (opposing pinnae inserted at $180^{\circ}$ on rhachis), with 140-210 pinnae, consistently terminated by paired pinnae; petiole grey-tomentose, $8-20 \mathrm{~cm}$ long, spinescent fo $5-50 \%$ of total length (often with only 3 or 4 distal spines); median pinnae at $70-80^{\circ}$ to rhachis, 90-180 mm long, 5.5-9.5 mm wide, grey-white tomentose, becoming glabrous on older leaves, glossy mid-green, flat in section with flat or slightly recurved margins, decurrent for $1.5-5 \mathrm{~mm}$, narrowed to $4-6.5 \mathrm{~mm}$ at base (c. $70 \%$ of maximum width), $6-13 \mathrm{~mm}$ apart on rhachis, apex acute; midrib not or slightly raised above, prominent below. New growth densely tomentose with grey-white and some pale orange-brown trichomes, usually persistent. Cataphylls slender, orange-brown-tomentose, $7-13 \mathrm{~cm}$ long. Microsporangiate cones elongate-ovoid, 18-24 cm long, 7-9 cm diam. Microsporophyll lamina 20-24 mm long, 11-15 mm wide, abruptly narrowed; sterile apex 7-13 mm long, recurved, apical spine sharply upturned, 5-11 mm long. Megasporophylls $17-24 \mathrm{~cm}$ long, brown-tomentose, with 2-6 ovules, sterile apex $50-90 \mathrm{~mm}$ long, 14-19 mm wide, narrowly triangular, regularly dentate with 6-20 lateral teeth, apical spine $20-35 \mathrm{~mm}$ long, lateral teeth $2-4 \mathrm{~mm}$ long, 2-3 $\mathrm{m}$ wide. Seeds ovoid, green becoming yellowish, pruinose, 27-31 mm long, 26-30 mm diam.; sarcotesta 2-3 mm thick. Fig. 27.

Leaf anatomy: upper mesophyll interrupted at midrib, composed of palisade and equidimensional cells; lower mesophyll interrupted at midrib, composed of equidimensional and palisade cells; laminar hypodermis discontinuous, 1 cell layer thick where present; marginal hypodermis 2 cell layers thick; stomatal crypts deep, closed; subsidiary cells raised and differentiated; cuticle thick.

Notes: distinguished by the flat leaves with perpendicular, broad, white-tomentose but non-glaucous pinnae with slightly recurved margins.

Distribution: a widespread species in the northern Kimberley region of Western Australia, from offshore islands west of Port Warrender to around Kalumburu (Fig. 25). All known occurrences are on skeletal red or grey clays on stony basalt slopes. Populations on the southern parts of the Mitchell Plateau are intergradational with C. lane-poolei.

Conservation status: not considered to be at risk.

Selected specimens: Western Australia: Gardner: SE part of Bougainville Peninsula, Beard 8285, 11 Sep 1978 (PERTH, DNA); Careening Bay, George 12810, 29 Aug 1974 (PERTH, DNA); 30 km 
from old Mitchell Plateau mining camp on Port Warrender track, Hill 4079, a \& Stanberg, 15 Sep 1991 (NSW, CANB); $43.8 \mathrm{~km}$ N of Mitchell Falls turnoff on Kalumburu road, Hill 4084, $4084 A$ \& Stanberg, 16 Sep 1991 (NSW, CANB); 15 miles [24 km] W of Theda old homestead, Maconochie 1239, 29 May 1971 (DNA, K, NSW); 34 km S of Kalumburu Mission, Maconochie 1266,

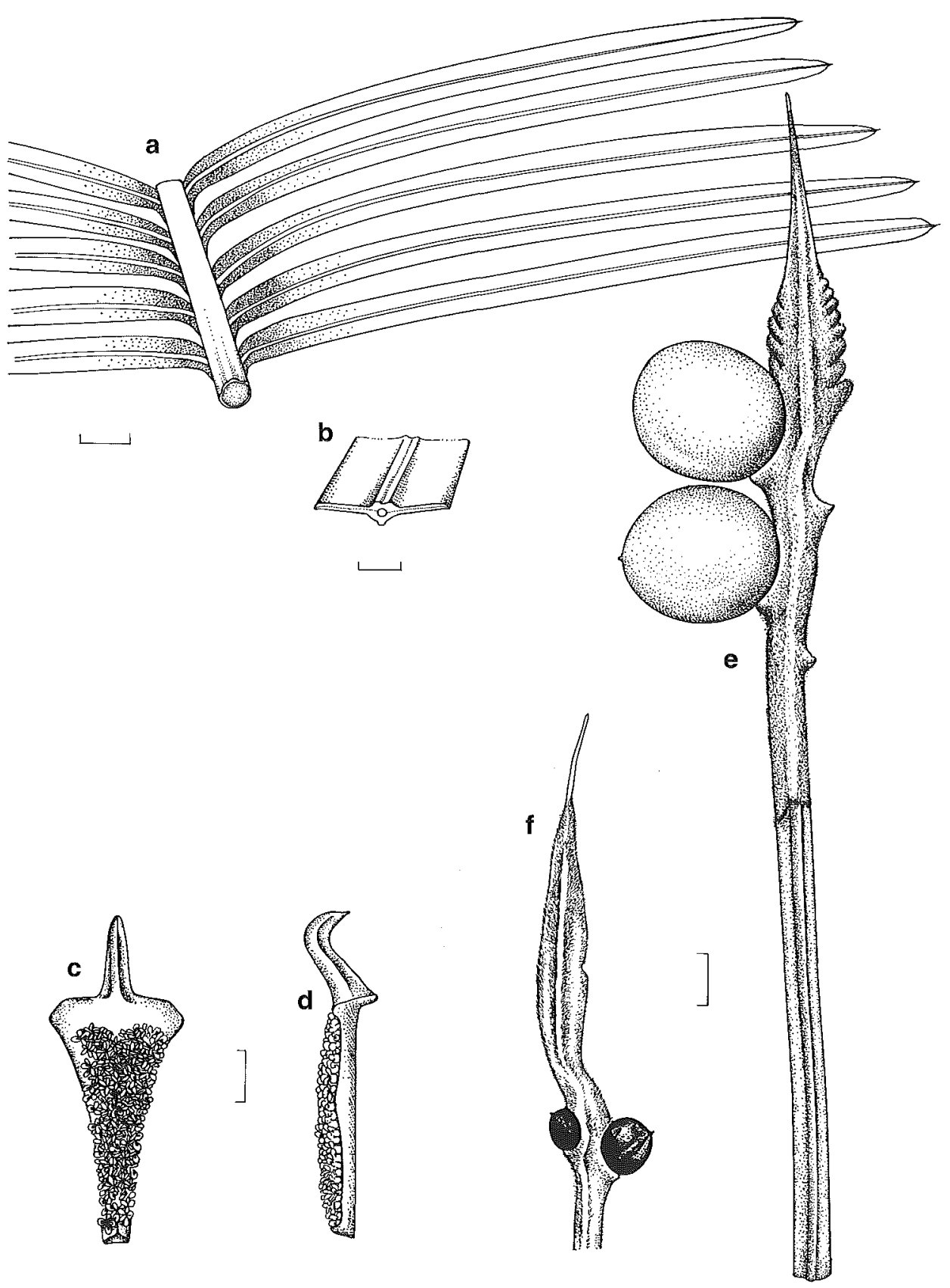

Fig. 27. C. basaltica. a, part of leaf. b, section of pinna. $\mathbf{c}$, d, microsporophyll. $\mathbf{e}$, megasporophyll with seed and stipe, $\mathrm{f}$, tip of megasporophyll (a, b, c, d from Hill 4079, e from Hill 4079a, from Maconochie 1239). Scale bar: $\mathrm{a}, \mathrm{e}, \mathrm{f}=1 \mathrm{~cm} ; \mathrm{b}=2 \mathrm{~mm} ; \mathrm{c}, \mathrm{d}=5 \mathrm{~mm}$. 
31 May 1971 (DNA, BRI); 19 miles [31 km] N of Amax bauxite camp, Maconochie 1269, 1 Jun 1971 (DNA, AD, K); $41.5 \mathrm{~km}$ S of Carson River on Kalumburu-Drysdale River road, McGillivray 3866 A \& George, 25 Jun 1978 (NSW); $5 \mathrm{~km}$ from Port Warrender towards Mitchell Plateau, Rodd 2902, 26 Oct 1974 (NSW); $9 \mathrm{~km}$ from new Theda homestead on Kalumburu road, Telford 6240 \& Butler, $28 \mathrm{Jul} 1977$ (CBG, DNA).

27. Cycas pruinosa Maconochie, J. Adelaide Bot. Gard. 1(3) : 177(1978).

Type: Western Australia, Ternonis Gorge, Durack Ranges ( $\left.17^{\circ} 25^{\prime} \mathrm{S}, 127^{\circ} 20^{\prime} \mathrm{E}\right)$, D. Symon s.n., June 1975 (holo NT; iso BRI, CANB, K, L, NSW, PERTH).

Illustration: Maconochie (1978: 176, Fig. 2).

Stem to $1.5 \mathrm{~m}$ tall, rarely to $2.5 \mathrm{~m}, 15-25$, rarely $30 \mathrm{~cm}$ diam. Leaves $60-125 \mathrm{~cm}$ long, keeled in section (opposing pinnae inserted at $45-90^{\circ}$ on rhachis), with $130-320$ pinnae, usually terminated by paired pinnae or occasionally a short spine to $4 \mathrm{~mm}$ long; petiole glabrous or white-tomentose, 8-23 cm long, spinescent for $50-100 \%$ fo length; median pinnae at $40-60^{\circ}$ to rhachis, $110-170 \mathrm{~mm}$ long, $2.5-4.0 \mathrm{~mm}$ wide, glabrous, usually glaucous, margins strongly recurved, decurrent for $2.5-4.0 \mathrm{~mm}$, narrowed to $2.0-3.0 \mathrm{~mm}$ at base ( $80-100 \%$ of maximum width), spaced at $5-9 \mathrm{~mm}$ on rhachis, apex attenuate; midrib raised above, prominent below. New growth densely tomentose with grey-white trichomes. Cataphylls densely pale orange-browntomentose, to $7 \mathrm{~cm}$ long. Microsporangiate cones fusiform, pale brown, 35-45 cm long, 5-7 cm diam. Microsporophyll lamina 12-18 $\mathrm{mm}$ long, $8-13 \mathrm{~mm}$ wide; sterile apex 9-14 $\mathrm{mm}$ long, recurved, apical spine slender, sharply upturned, 6-25 $\mathrm{mm}$ long. Megasporophylls 25-45 cm long, grey- and pale orange-brown-tomentose, with 2-6 ovules, sterile apex $95-190 \mathrm{~mm}$ long, $18-40 \mathrm{~mm}$ wide, narrowly triangular, regularly deeply dentate, with 14-24 lateral teeth, apical spine 10-45 $\mathrm{mm}$ long, lateral teeth 5-20 mm long, 2-4 mm wide. Seeds flattened-ovoid, green becoming yellow, strongly pruinose, 32-36 mm long, 28-32 mm diam.; sarcotesta 2-3 mm thick. Fig. 28.

Leaf anatomy: upper mesophyll continuous, composed of palisade and equidimensional cells; lower mesophyll interrupted at midrib, composed of equidimensional and palisade cells; laminar hypodermis discontinuous or continuous, 1-2 cell layers thick where present; marginal hypodermis 1 cell layer thick; stomatal crypts deep, closed; subsidiary cells raised and differentiated; cuticle very thick.

Notes: distinguished by the narrow glabrous pinnae with strongly recurved margins, the long, slender microsporangiate cones, and the long megasporophylls with long sterile apices.

Glaucous leaf waxes may be either present or absent, causing plants to be either blue or green in overall appearance. This is apparently genetically controlled, different populations being completely blue (e.g. those at Lake Argyle and Bedford Downs), completely green (e.g. those at Deception Range) or mixed (e.g. those at Cycad Hill). A similar phenomenon occurs in C. furfuracea (below), in this case the green plants being very much less common and never occurring without the blue plants.

Distribution: a widespread but sporadic species in the eastern and southern Kimberley region of Western Australia, occurring also in the Spirit Hills on Bullo River station in the Northern Territory (Fig. 25). Found on mainly skeletal sandy soils on siliceous substrates, from metasandstones to granites. One occurrence in Western Australia is, however, on red Terra Rosa soil on limestone (near Tunnel Creek, in the Napier Range). 

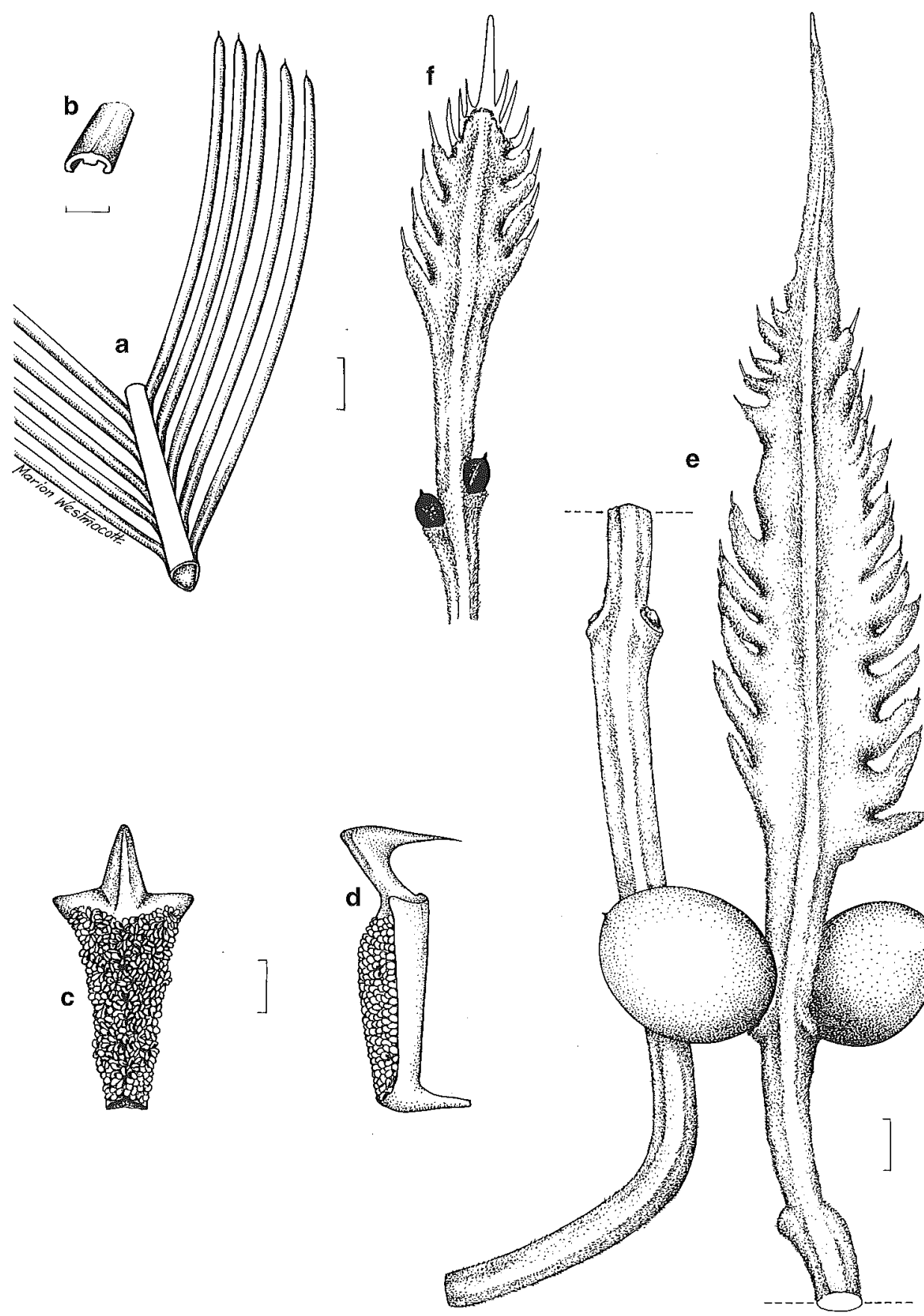

Fig. 28. C. pruinosa. $\mathbf{a}$, part of leaf. $\mathbf{b}$, section of pinna. $c$, d, microsporophyll. e, megasporophyll with seed and stipe. $\mathrm{f}$, tip of megasporophyll ( $\mathrm{a}, \mathrm{b}$, e from Hill 4117, d from Hill 4117a, f from Hill 3482). Scale bar: $a, e, f=1 \mathrm{~cm} ; b=2 \mathrm{~mm} ; c, d=5 \mathrm{~mm}$. 
Conservation status: not considered to be at risk.

Selected specimens: Northern Territory: Victoria River: Spirit Hills, Bullo River Station, Dunlop 10160, 10162 \& Walsh, 9 May 1995 (DNA, NSW). Western Australia: Dampier: near Cycad Hill, Hill 4115 \& Stanberg, 22 Sep 1991 (NSW, CANB). Fitzgerald: Cliffs to SW of Elgee Jump Up, Hill 3482, Johnson \& Stanberg, 26 Nov 1988 (NSW, PERTH); $32 \mathrm{~km}$ from highway on Bedford Downs road (near Black Hill), Hill 4117 \& Stanberg, 23 Sep 1991 (NSW, CANB). Gardner: Lake Argyle, below dam wall, Hill 4119 \& Stanberg, 23 Sep 1991 (NSW); The Grotto, Carr Boyd Range near Kununurra, Perry 3073, 26 Jul 1952 (CANB, NSW); Deception Range, Peter Wilson 843 \& Rotve, 30 Aug 1991 (NSW).

\section{Acknowledgements}

Leonie Stanberg has provided valuable technical assistance in the field and laboratory. Peter Wilson is thanked for assistance with the Latin diagnoses of new taxa. Cycad enthusiasts who have contributed materially with their field knowledge have been Monty Anderson and Craig Walker of Darwin, Joe Perner of Katherine, and Stan Walkely of Burpengary. Sharon Chirgwin is acknowledged for valuable discussions of taxonomic problems. Lesley Elkan, Nicola Oram and Marion Westmacott provided the illustrations. The directors of the herbaria DNA, MEL, PERTH and BRI are thanked for the loan of important specimens, the former also most importantly for access to notes and collections left by the late John Maconochie.

\section{References}

Amoroso, V.B. (1986) Morphological study of the sporophylls of Philippine Cycas. Philippine Joumal of Science 115(3): 177-198.

Bailey, F.M. (1883) A synopsis of the Queensland flora (Govt Printer: Brisbane).

Bailey, F.M. (1902) Queensland Flora vol. 5 (Govt Printer: Brisbane).

Bailey, F.M. (1913) Comprehensive catalogue of Queensland plants (Govt Printer: Brisbane).

Bentham, G. (1873) Cycadeae. Pp. 248-254 in Flora Australiensis vol. 6 (Reeve: London).

Brown, R. (1810) Prodromus florae Novae Hollandiae et insulae Van-Dieman (Taylor: London).

Chirgwin, S.K. and Wigston, D. (1993) A new species of Cycas from the Northern Territory. Joumal of the Adelaide Botanic Garden 15(2): 147-148.

Dehgan, B. and Yuen, C.K.K.H. (1983) Seed morphology in relation to dispersal, evolution and propagation of Cycas L. Botanical Gazette 144: 412-418.

Elliot, W.R. and Jones, D.L. (1984) Encyclopedia of Australian Plants, vol. 3 (Lothian: Melbourne).

Ewart, A.J. and Davies, O.B. (1917) The flora of the Northern Territory (McCarron, Bird \& Co.: Melbourne).

Fitzgerald, W.V. (1918) The botany of the Kimberleys. Journal and

Proceedings of the Royal Society of Western Australia 3: 102-224.

Forster, P.I. (1995) Cycas desolata (Cycadaceae), a new species from north Queensland. Austrobaileya 4: 345aileya, a new sp

Gardner, C.A. (1922) Western Australian trees. No. 48. Cycad palm (Cycas lane-poolei). Western Australian Mail 16 Mar 1922: 30, ill. 25.

Gardner, C.A. (1923) Botanical notes. Bulletin of the Forests Department of Western Australia 32: 30-32.

Hill, K.D. (1992) A preliminary account of Cycas (Cycadaceae) in Queensland. Telopea 5(1): 177-206.

Hill, K.D. (1993) Cycas arenicola (Cycadaceae), a new species from the Northern Territory of Australia. Telopen 5(2): 419-422.

Hill, K.D. (1994a) Three new species of Cycas (Cycadaceae) from the Northern Territory of Australia. Telopea 5(4): 693-701.

Hill, K.D. (1994b) The Cycas media group (Cycadaceae) in New Guinea. Australian Systematic Botany 7: 527-541.

Hill, K.D. (1995). The genus Cycas (Cycadacae) in the Indian region, with notes on the application and typification of the name Cycas circinalis L. Taxon 44, 23-31.

Hill, K.D. (1996) Evolution and biogeography of the genus Cycas. In Vorster, P. (ed.), Proc. 3rd Intl Conf. Cycad Biol. 
Holmgren, P.K., Holmgren, N.H. \& Barnett, L.C. (1990) Index Herbariorum edn 8 (New York Botanical Garden: New York).

Johnson, L.A.S. (1959) The families of cycads and the Zamiaceae of Australia. Proceedings of the Linnaean Society of New South Wales 84(1): 64-117.

Lamb, M.A. (1923) Leaflets of Cycadaceae. Bot. Gnz. 76: 185-202.

Linnaeus, C. (1753) Species Plantarum, vol. 1. (1960 facsimile edn, H.R. Engelmann: Weinheim).

Linnaeus, C. (1754) Genern Plantarum edn 5 (1934 facsimile edn., Shokobutu Bunken: Tokyo).

Maconochie, J.R. (1978) Two new species of Cycas from northern Australia. Jottmal of the Adelaide Botanic Garden 1: 175-178.

Maconochie, J.R. (1980) Key to Cycas, in Clifford, H.T. and Constantine, J., Ferns, fern allies and conifers of Australia (Univ. Qld Press: St Lucia).

Miquel, F.A.W. (1840) Commentarii phytographici (Luchtmans: Leiden).

Miquel, F.A.W. (1842) Monographia cycadearum (Rhenum: Utrecht).

Miquel, F.A.W. (1847) Collectanea nova ad cycadearum cognitionem. Linnaea 19: 411-430.

Miquel, F.A.W. (1868) Nouveaux matériaux pour servir à la connaissance des Cycadées. Arch. Néerl. Sci. Exact. Nat. 3(5): 193-254, 403-427.

Miquel, F.A.W. (1869) Nieuwe bijdragen tot de kennis der Cycadeen. Vers. Med. Afd. Nat. Kon. Aknd. Wetensch. ser. 2, 3(1): 1-57; 3(2): 152-165, 196-206; 4: 2-37.

Mueller, F. (1874) Fragmenta Phytographie Australine 8 (Govt. Printer: Melbourne).

Mueller, F. (1876) Fragmenta Phytographie Australine 10 (Govt. Printer: Melbourne).

Mueller, F. (1882) Notes on a hitherto undefined species of Cycas. Australian Chemist and Druggist $4(47): 85$.

Pilger, R. (1926) Cycadaceae. Pp. 44-82 in Engler, A., ed. Die naturtichen Pflanzenfamilien, ed. 2, 13: $44-82$.

Rheede, H.A. (1682) Hortus indicus malabaricus vol. 3 (Amsterdam).

Schuster, J. (1932) Cycadaceae. Pp. 1-168 in Engler, A. (ed.) Das Pflanzenreich 99(4,1). 


\section{Appendix. Hybrids and intermediate forms}

C. armstrongii $\times$ C. conferta

Northern Territory: Darwin \& Gulf: $15 \mathrm{~km}$ from old highway on Daly River road, Hill $4058 \mathcal{E}$ Stanberg, 10 Sep 1991 (NSW, CANB, DNA).

C. armstrongii $\times$ C. maconochiei

Northern Territory: Darwin \& Gulf: Leviathan Creek, on Fog Bay road, Anderson s.n., 25 Apr 1993 (NSW 270256).

C. arnhemica $-C$. orientis intergrades

Northern Territory: Darwin \& Gulf: $64.9 \mathrm{~km}$ E of Ramangining turnoff on Gove road (Badalngarrmirri Creek), Hill 3930 \& Stanberg, 25 Aug 1991 (NSW); Arnhem Land, Maconochie 1510, 17 Jun 1972 (DNA, AK); c. 5 km NE of McLaren River crossing, Maconochie 1622, 23 June 1972 (DNA, CANB, K).

C. basaltica-C. lane-poolei intergrades

$5 \mathrm{~km}$ N of Mitchell Stn homestead, Perner s.n., 28 Oct 1993 (NSW, BRI, CANB); $7.5 \mathrm{~km}$ N of Mitchell Stn homestead, Perner s.n., 28 Oct 1993 (NSW, CANB); N of Mitchell Homestead on track to plateau, Perner s.n., 25 Oct 1994 (NSW, BRI, DNA, K, L, PE).

C. calcicola $\times$ C. conferta

Northern Territory: Darwin \& Gulf: Blackfellows creek, Hill 4462 \& Perner, 5 Sep 1993 (NSW).

C. media - C. ophiolitica intergrades

Queensland: Port Curtis: $48 \mathrm{~km}$ N of Marlborough on Bruce Highway (via Lotus Creek), Hind 2878, 30 Dec 1980 (NSW); $40.3 \mathrm{~km}$ N of Marlborough, on Bruce Highway, Hind 2619, 11 Apr 1980 (NSW).

C. media - C. platyphylla intergrades

Queensland: Cook: Stannary Hills, W of Herberton, Blaxell 88/202, 2 Aug 1988 (NSW); $1.5 \mathrm{~km}$ from Irvinebank on Herberton road, Hill 3766 \& Stanberg, 1 Aug 1990 (NSW, BRI, CANB, MEL, DNA); c. $10 \mathrm{~km} \mathrm{NW}$ of Bakerville (Stannary Hills area), Harris 1, 12 Sep 1974 (NSW); 2 km E of Irvine Bank [Irvinebank], Maconochie 2668, 13 Jun 1981 (NSW, NT, BRI, NSW, L, CBS).

C. megacarpa-C. ophiolitica intergrades

Queensland: Port Curtis: $21.8 \mathrm{~km}$ from Bruce Highway on road to Mount Morgan, Hill 3799 \& Stanberg, 8 Aug 1990 (NSW, BRI, CANB, DNA); 10 km E of Mount Morgan, Hind 2844, 21 Dec 1980 (NSW). 